SGW-47535

Revision 0

\title{
Measurement of Compressional-Wave Seismic Velocities in 29 Wells at the Hanford Site
}

Prepared for the U.S. Department of Energy Assistant Secretary for Environmental Management Contractor for the U.S. Department of Energy under Contract DE-AC06-08RL14788

CH2NHILL

Plateau Remediation Company

P.O. Box 1600

Richland, Washington 99352 


\section{Measurement of Compressional- Wave}

\section{Seismic Velocities in 29 \\ Wells at the Hanford Site}

Petersen s $W$

Date Published

October 2010

Prepared for the U.S. Department of Energy

Assistant Secretary for Environmental Management

Contractor for the U.S. Department of Energy

under Contract DE-AC06-08RL14788

CH2WHILL

Plateau Remediation Company

P.O. Box 1600

Richland, Washington

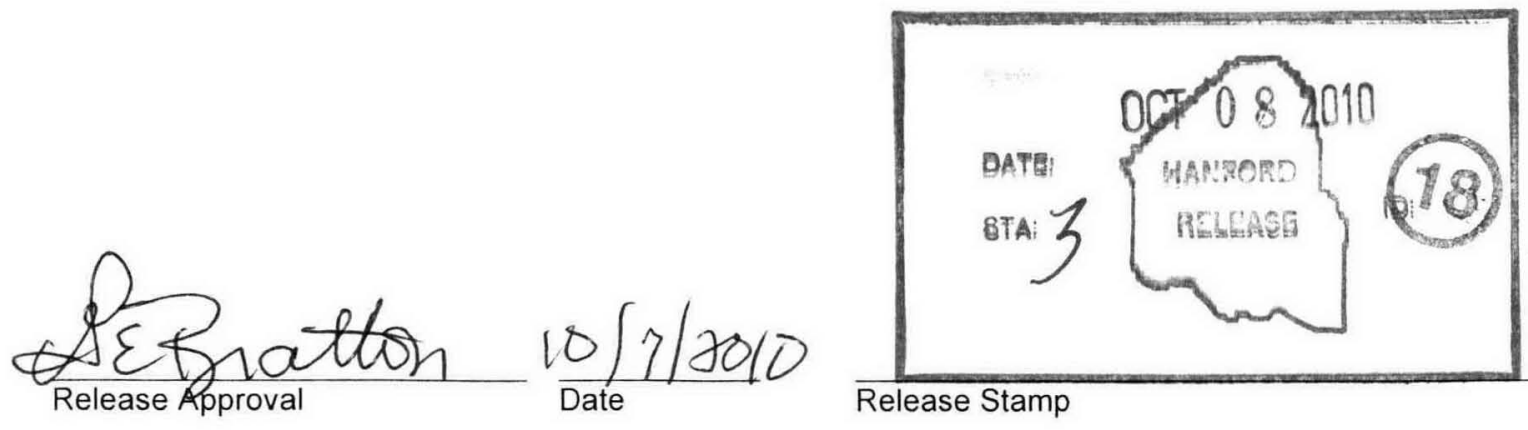


SGW-47535

Revision 0

TRADEMARK DISCLAIMER

Reference herein to any specific commercial product, process,

or service by trade name, trademark, manufacturer, or

otherwise, does not necessarily constitute or imply its

endorsement, recommendation, or favoring by the United

States Government or any agency thereof or its contractors or subcontractors.

This report has been reproduced from the best available copy.

Printed in the United States of America

Total Pages: 


\section{Contents}

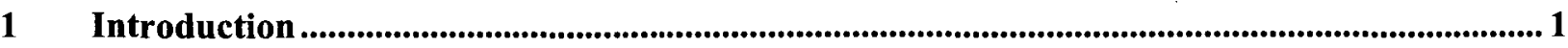

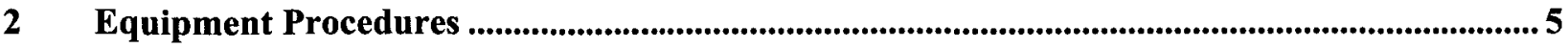

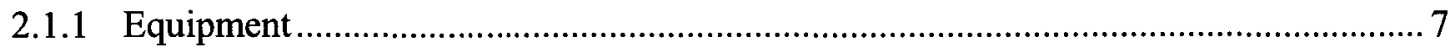

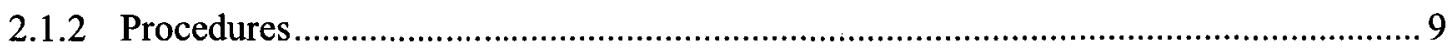

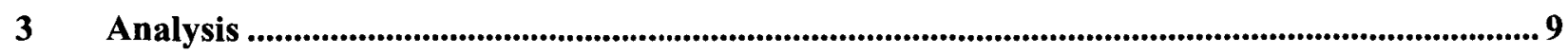

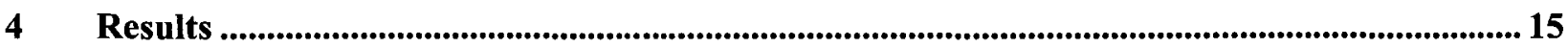

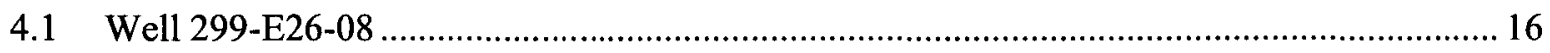

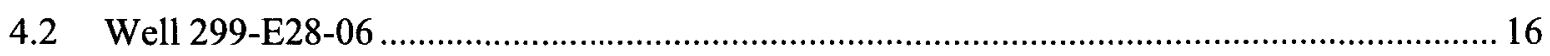

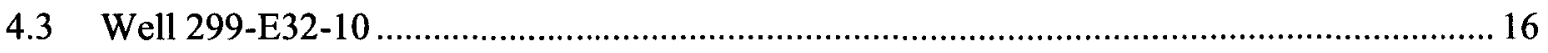

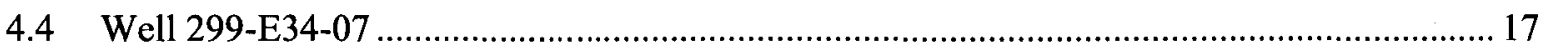

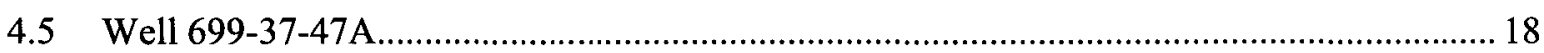

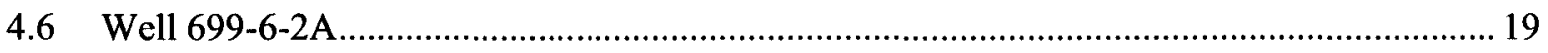

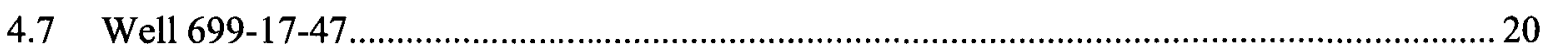

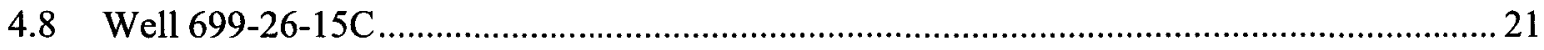

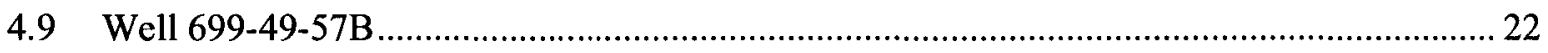

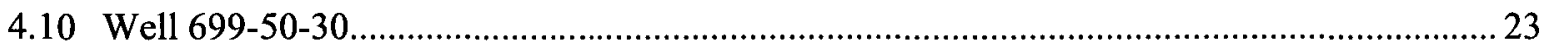

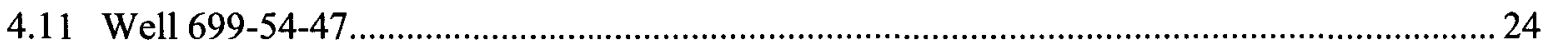

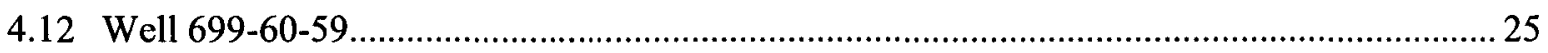

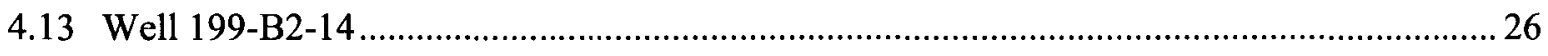

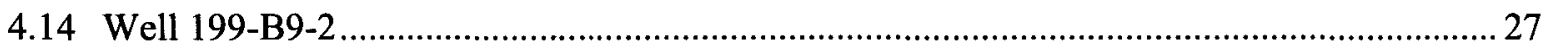

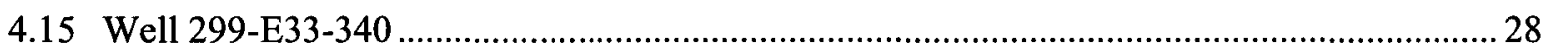

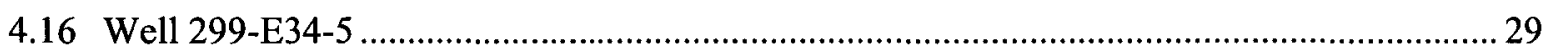

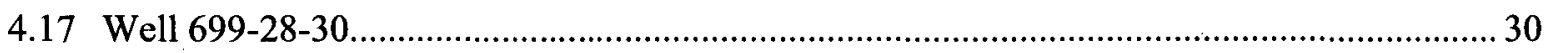

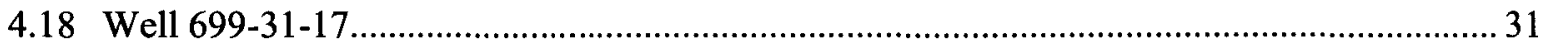

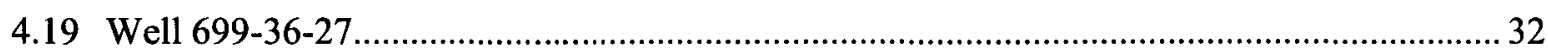

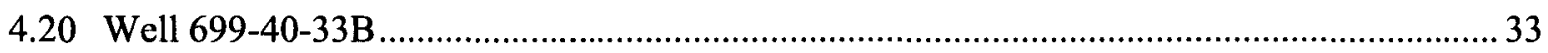

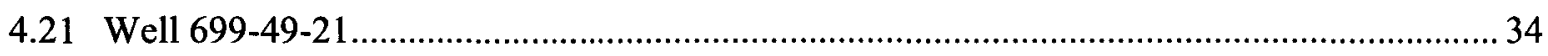

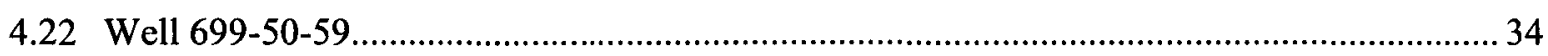

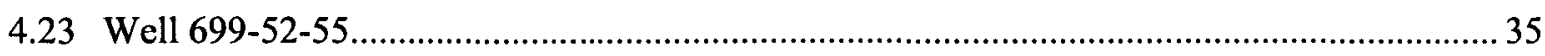

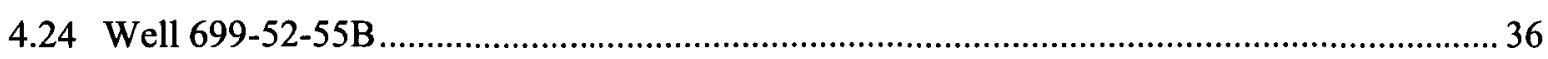

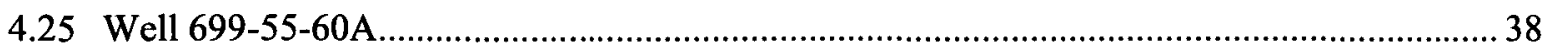

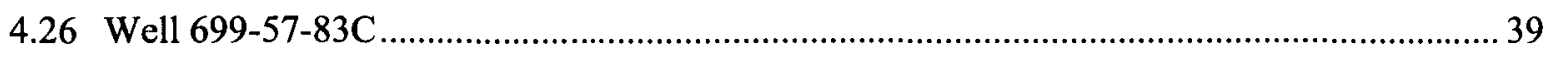

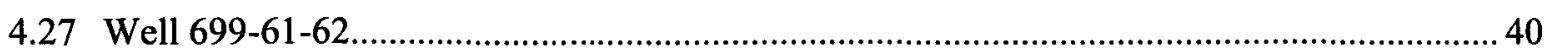

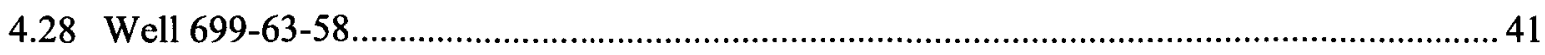

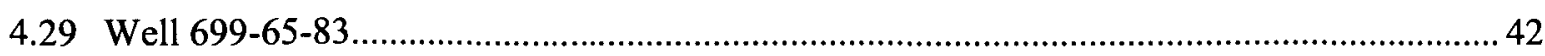




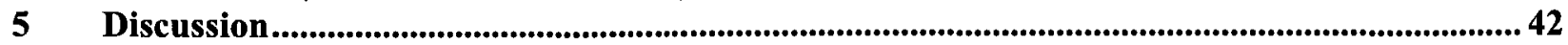

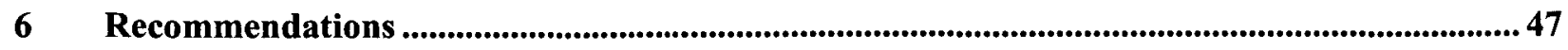

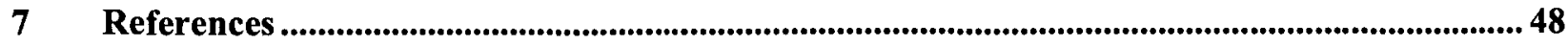

\section{Appendices}

Figures

Figure 1. Check Shot Survey Well Locations................................................................................ 1

Figure 2. 200 East Area: Check Shot Surveys ................................................................................ 2

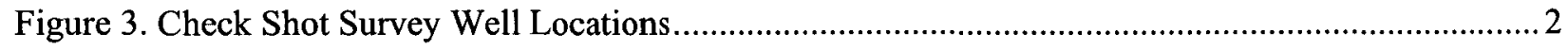

Figure 4. Gable Gap: Check Shot Survey Well Locations.................................................................. 3

Figure 5. 100 B/C Areas: Check Shot Survey Well Locations ............................................................. 3

Figure 6. Check Shot Survey Setup and Example Shot Record ........................................................ 6

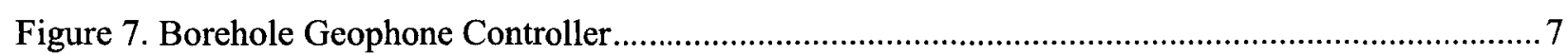

Figure 8. Geostuff Model BHG-2 Borehole Geophone (with Sidewall Clamp).......................................

Figure 9. ATV Mounted Accelerated Weight Drop...................................................................... 8

Figure 10. Well 299-E34-7: Reference Geophone Arrivals............................................................. 11

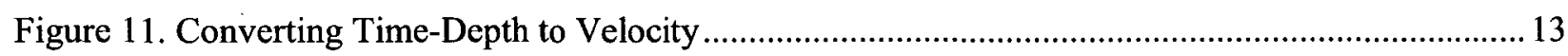

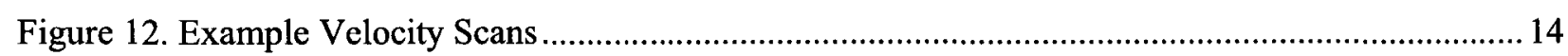

Figure 13. Check Shot Survey Results for Well 299-E26-08 ........................................................... 16

Figure 14. Check Shot Survey Results for Well 299-E28-06 ........................................................... 16

Figure 15. Check Shot Survey Results for Well 299-E32-10 ............................................................ 17

Figure 16. Check Shot Survey Results for Well 299-E34-07 .......................................................... 18

Figure 17. Check Shot Survey Results for Well 699-37-47A............................................................ 19

Figure 18. Check Shot Survey Results for Well 699-6-2A.................................................................20

Figure 19. Check Shot Survey Results for Well 699-17-47............................................................21

Figure 20. Check Shot Survey Results for Well 699-26-15C...........................................................22

Figure 21. Check Shot Survey Results for Well 699-49-57B .........................................................23

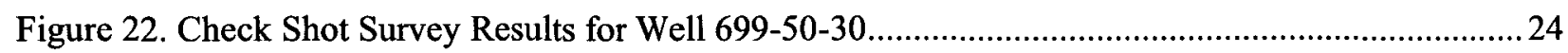

Figure 23. Check Shot Survey Results for Well 699-54-57...............................................................25

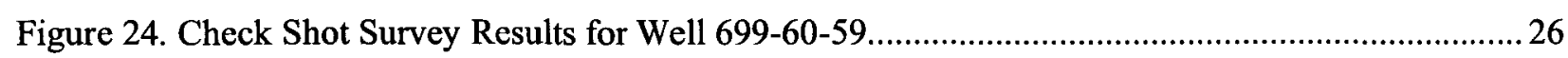

Figure 25. Check Shot Survey Results for Well 199-B2-14 ..........................................................27

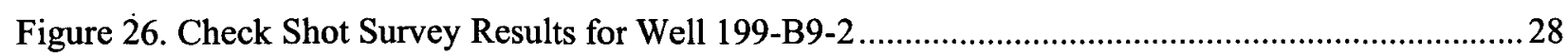

Figure 27. Check Shot Survey Results for Well 299-E33-340 ..............................................................29

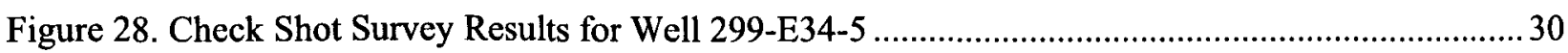

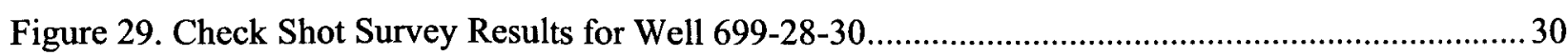

Figure 30. Check Shot Survey Results for Well 699-31-17 ........................................................... 31 
Figure 31. Check Shot Survey Results for Well 699-36-27........................................................... 32

Figure 32. Check Shot Survey Results for Well 699-40-33B ........................................................... 33

Figure 33. Check Shot Survey Results for Well 699-49-21 ............................................................. 34

Figure 34. Check Shot Survey Results for Well 699-50-59...................................................... 35

Figure 35. Check Shot Survey Results for Well 699-52-55................................................................. 36

Figure 36. Check Shot Survey Results for Well 699-52-55B ......................................................... 37

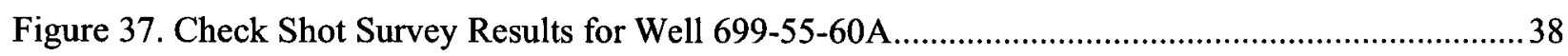

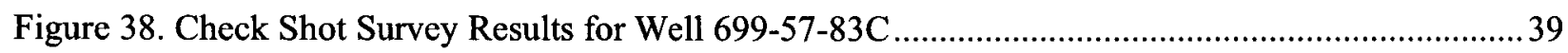

Figure 39. Check Shot Survey Results for Well 699-61-62 ..............................................................40

Figure 40. Check Shot Survey Results for Well 699-63-58................................................................ 41

Figure 41. Check Shot Survey Results for Well 699-65-83.............................................................. 42

Figure 42. Seismic Velocities: 29 Check Shot Surveys, Fiscal Year 2008 to Fiscal Year 2010 ..............43

Figure 43. Seismic Velocities: 29 Check Shot Surveys, Fiscal Year 2008 to Fiscal Year 2010 ............... 44

Figure 44. Check Shot Surveys, Geologic Units, and Seismic Reflectors ........................................... 45

Figure 45. 200 East: Compressional-Wave Velocities ..........................................................................46

Figure 46. Gable Gap: Compressional-Wave Velocities .................................................................46

Figure 47. Cold Creek Basin: Compressional-Wave Velocities .......................................................... 47

Tables

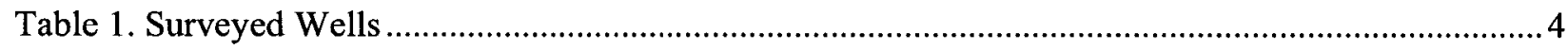


SGW-47535, REV. 0 
SGW-47535, REV. 0

\section{Terms}

$\begin{array}{ll}\text { bgs } & \text { below ground surface } \\ \text { BWIP } & \text { Basalt Waste Isolation Program } \\ \text { CCU } & \text { Cold Creek Unit } \\ \text { CS } & \text { carbon steel } \\ \text { DOE } & \text { U.S. Department of Energy } \\ \text { Ecology } & \text { Washington State Department of Ecology } \\ \text { EPA } & \text { U.S. Environmental Protection Agency } \\ \text { FY } & \text { fiscal year } \\ \text { OU } & \text { operable unit } \\ \text { PVC } & \text { polyvinyl chloride } \\ \text { RAD } & \text { radiation } \\ \text { SS } & \text { stainless steel }\end{array}$


SGW-47535, REV. 0 


\section{Introduction}

Check shot seismic velocity surveys were collected in 100 B/C, 200 East, 200-PO-1 Operational Unit $(\mathrm{OU})$, and the Gable Gap areas in order to provide time-depth correlation information to aid the interpretation of existing seismic reflection data acquired at the Hanford Site (Figure 1). This report details results from 5 wells surveyed in fiscal year (FY) 2008, 7 wells in FY 2009, and 17 wells in FY 2010 and provides summary compressional-wave seismic velocity information to help guide future seismic survey design as well as improve current interpretations of the seismic data (SSC 1979/1980; SGW-39675; SGW-43746). Augmenting the check shot database are four surveys acquired in 2007 in support of the Bechtel National, Inc. Waste Treatment Plant construction design (PNNL-16559, PNNL16652), and check shot surveys in three wells to support seismic testing in the 200 West Area (Waddell et al., 1999). Additional sonic logging was conducted during the late 1970s and early 1980s as part of the Basalt Waste Isolation Program (BWIP) (SSC 1979/1980) and check shot/sonic surveys as part of the safety report for the Skagit/Hanford Nuclear project (RDH/10-AMCP-0164).

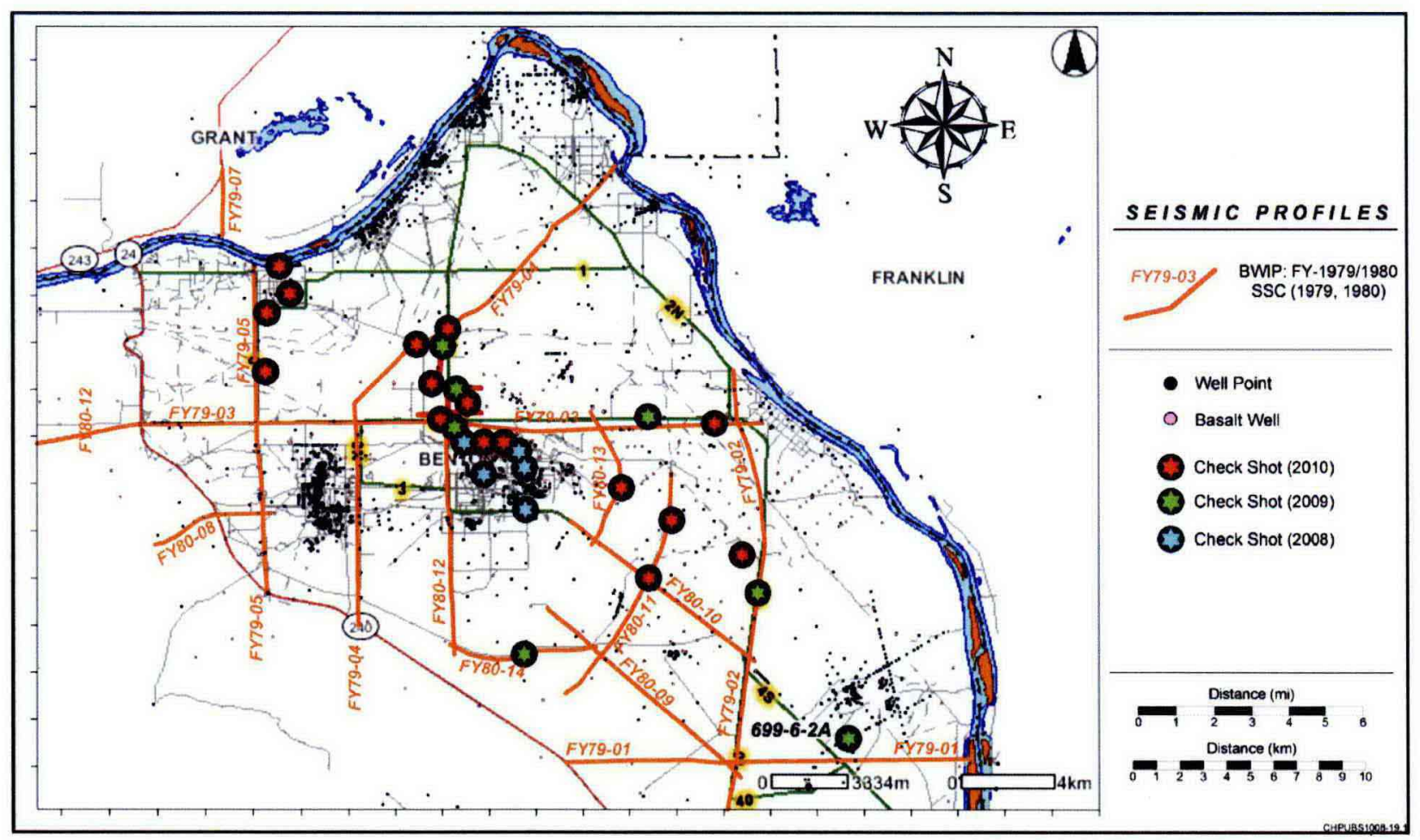

Figure 1. Check Shot Survey Well Locations

Check shot surveys are used to obtain an in situ measure of compressional-wave seismic velocity for sediment and rock in the vicinity of the well point, and provide the seismic-wave travel time to geologic horizons of interest. The check shot method deploys a downhole seismic receiver (geophone) to record the arrival of seismic waves generated by a source at the ground surface. The travel time of the first arriving seismic-wave is determined and used to create a time-depth function to correlate encountered geologic intervals with the seismic data. This critical tie with the underlying geology improves the interpretation of seismic reflection profile information.

Fieldwork for this investigation was conducted by in house staff during the weeks of September 22, 2008 for 5 wells in the 200 East Area (Figure 2); June 1, 2009 for 7 wells in the 200-PO-1 OU and Gable Gap regions (see Figure 3 and Figure 4); and March 22, 2010 and April 19, 2010 for 17 wells in the 200 East, 
200-PO-1 OU, Gable Gap, and 100-B/C areas (Figure 2 through Figure 5). Logging support was provided by the Stoller Corp.

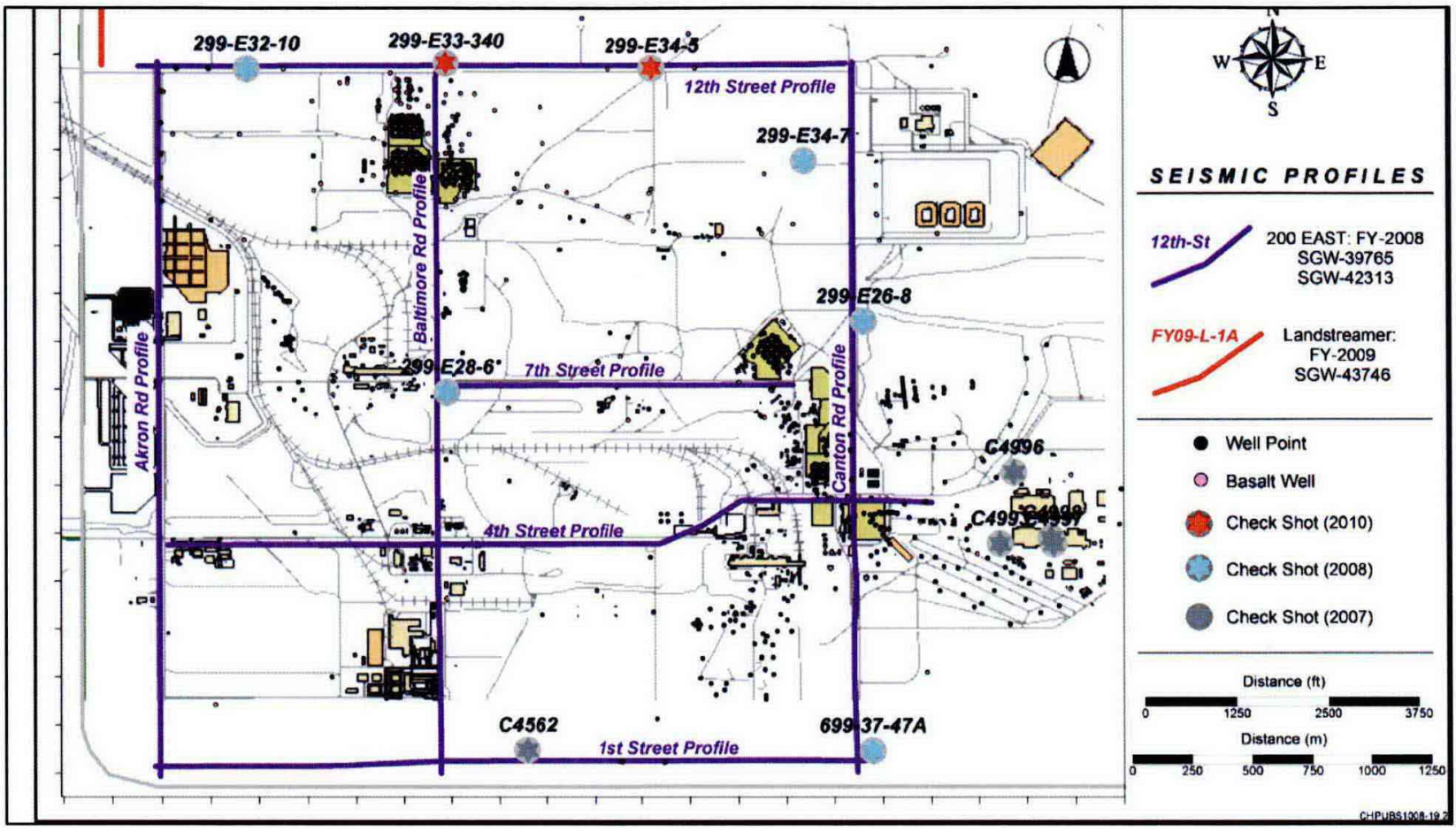

Figure 2. 200 East Area: Check Shot Surveys

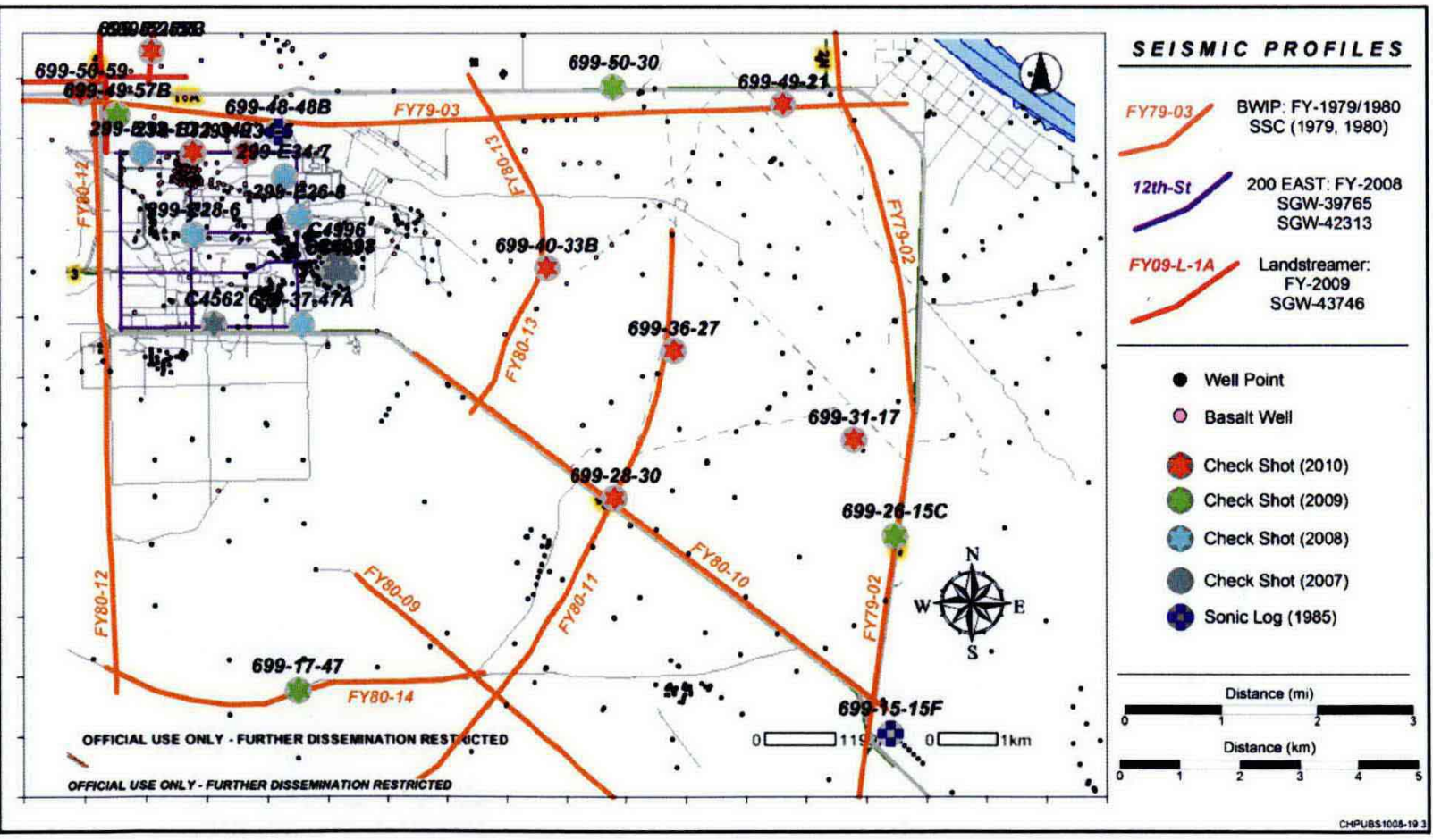

Figure 3. Check Shot Survey Well Locations 


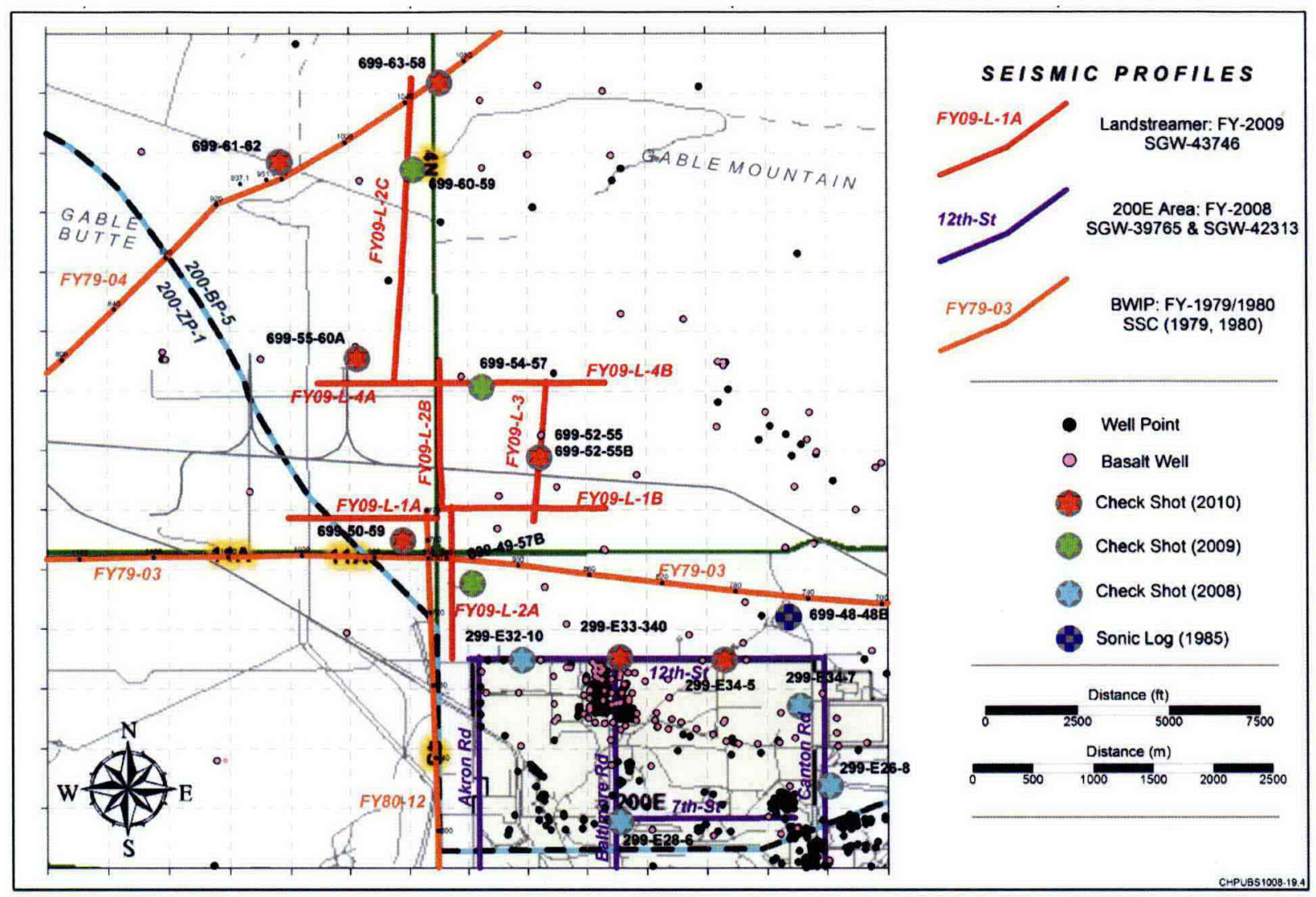

Figure 4. Gable Gap: Check Shot Survey Well Locations

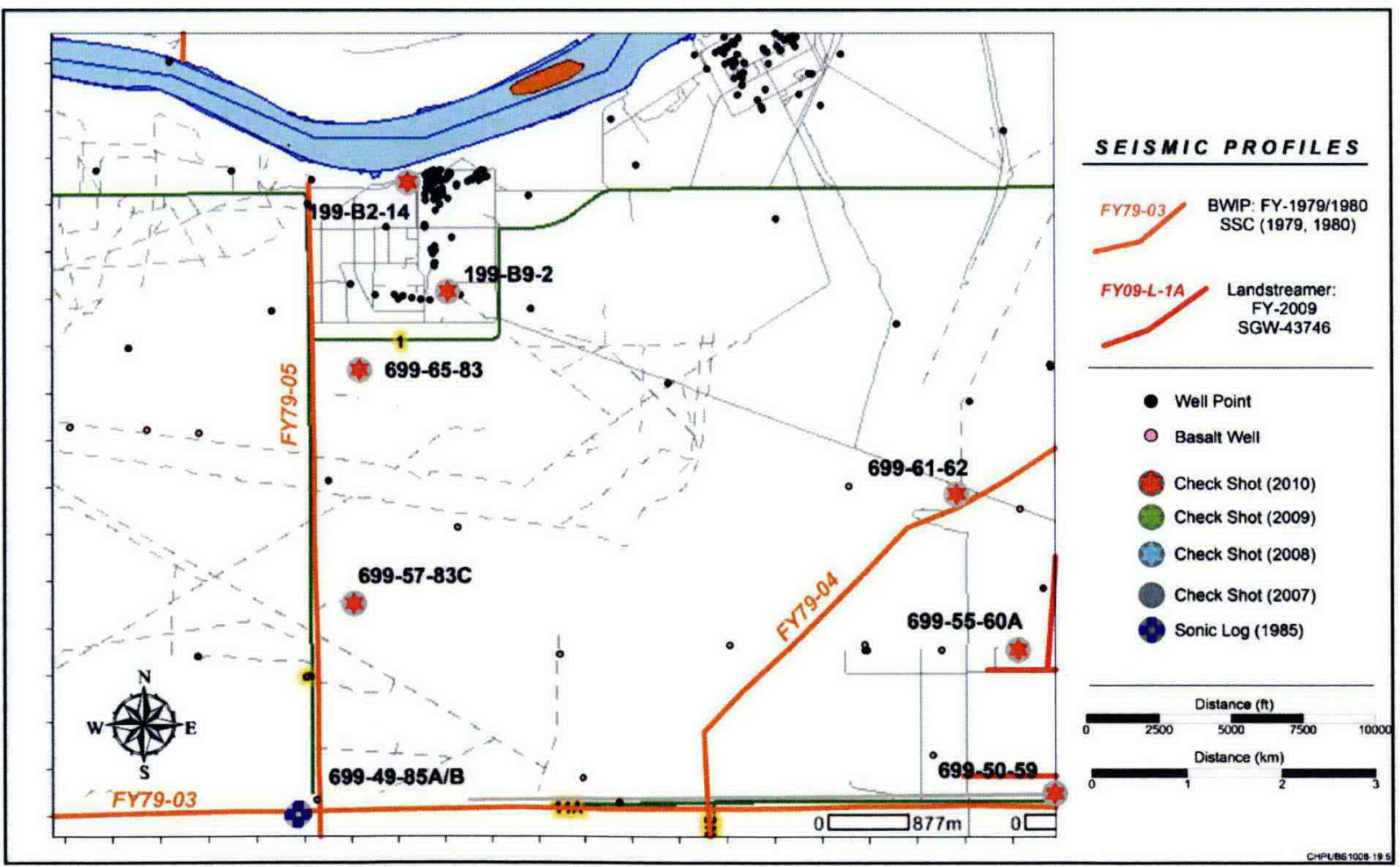

Figure 5. 100 B/C Areas: Check Shot Survey Well Locations 
The initial scope of survey work was planned for Wells 299-E18-1, 699-2-E14, 699-12-18, 699-16-51, 699-42-30, 699-53-55B, 699-54-18D, and 699-84-34B. Well 299-E18-1 could not be entered due to bent casing (prevented removal of the pump), wells 699-12-18 and 699-42-30 could not be safely reached by the logging truck, Well 699-16-51 was decommissioned prior to survey start, Well 699-53-55B did not have its pump pulled, and Wells 699-2-E14, 699-54-18D, and 699-84-34B are artesian and capped with an igloo structure. Table 1 provides a list of wells that were surveyed and Figure 1 through Figure 5 show the well locations relative to the Hanford Site.

Table 1. Surveyed Wells

\begin{tabular}{|c|c|c|c|c|c|}
\hline Well Name & $\begin{array}{l}\text { Depth of } \\
\text { Survey in } \mathrm{m} \\
\text { (ft) }\end{array}$ & Date of Survey & Geologic Units & Casing & Remarks \\
\hline 299-E26-8 & $122.5(402)$ & 24 Sep 2008 & $\begin{array}{c}\text { Hanford } \\
\text { Basalt }\end{array}$ & 8-in. CS & $\begin{array}{l}\text { Results not geologic, } \\
\text { casing tube-wave }\end{array}$ \\
\hline 299-E28-6 & $87.8(288)$ & 25 Sep 2008 & Hanford & 8-in. CS & $\begin{array}{l}\text { Sledgehammer } \\
\text { source, loss of signal } \\
\text { below } 88.4 \mathrm{~m}(290 \mathrm{ft}) \\
\text { bgs, Basalt } 110.6(\mathrm{~m}) \\
363 \mathrm{ft} \text { bgs }\end{array}$ \\
\hline 299-E32-10 & $73.8(242)$ & 24 Sep 2008 & Hanford & 4-in. CS & $\begin{array}{l}\text { Basalt: } 74.7 \mathrm{~m}(245 \mathrm{ft}) \\
\text { bgs }\end{array}$ \\
\hline 299-E34-7 & $61.6(202)$ & 23 Sep 2008 & Hanford & 4-in. CS & $\begin{array}{l}\text { Basalt: } 62.5 \mathrm{~m}(205 \mathrm{ft}) \\
\text { bgs }\end{array}$ \\
\hline $699-37-47 A$ & $100.3(329)$ & 23 Sep 2008 & $\begin{array}{l}\text { Hanford } \\
\text { Ringold }\end{array}$ & 4-in. CS & $\begin{array}{l}\text { Upper } 15.2 \mathrm{~m}(50 \mathrm{ft}) \text { of } \\
\text { Ringold }\end{array}$ \\
\hline $699-6-2 A$ & $22.6(74)$ & 3 Jun 2009 & Hanford & 8-in. CS & $\begin{array}{l}\text { Well collapsed below } \\
21.3 \mathrm{~m}(70 \mathrm{ft})\end{array}$ \\
\hline $699-17-47$ & $98.5(323)$ & 1 Jun 2009 & $\begin{array}{c}\text { Hanford } \\
\text { Ringold (?) }\end{array}$ & 4-in. CS & $\begin{array}{l}\text { Casing tube-wave } 15.2 \\
\mathrm{~m} \text { to } 54.9 \mathrm{~m}(50 \mathrm{ft} \\
\text { to } 180 \mathrm{ft}) ; \text { Basalt at } \\
103.9 \mathrm{~m}(341 \mathrm{ft}) \text { bgs }\end{array}$ \\
\hline $699-26-15 c$ & $190.5(625)$ & 2 Jun 2009 & $\begin{array}{l}\text { Hanford } \\
\text { Ringold (?) } \\
\text { Basalt }\end{array}$ & 4-in. CS & $\begin{array}{l}\text { Basalt: } 184.4 \mathrm{~m} \mathrm{(605} \\
\text { ft) bgs }\end{array}$ \\
\hline 699-49-57B & 70.4 (231) & 2 Jun 2009 & $\begin{array}{l}\text { Hanford } \\
\text { Basalt }\end{array}$ & 6-in. CS & $\begin{array}{l}\text { Basalt: } 49.4 \mathrm{~m}(162 \mathrm{ft}) \\
\text { bgs and top-of- } \\
\text { Interbed }\end{array}$ \\
\hline $699-50-30$ & 43.9 (144) & 4 Jun 2009 & $\begin{array}{l}\text { Hanford } \\
\text { Ringold (?) }\end{array}$ & 8-in. CS & $\begin{array}{l}\text { Well plugged at } 44.2 \mathrm{~m} \\
\text { (145 ft), possible } \\
\text { Ringold near bottom }\end{array}$ \\
\hline $699-54-57$ & 72.5 (238) & 4 Jun 2009 & $\begin{array}{c}\text { Hanford } \\
\text { Basalt }\end{array}$ & 6-in. CS & $\begin{array}{l}\text { Basalt: } 55.2 \mathrm{~m}(181 \mathrm{ft}) \\
\text { bgs }\end{array}$ \\
\hline $699-60-59$ & $157(515)$ & 3 Jun 2009 & $\begin{array}{l}\text { Hanford } \\
\text { Basalt }\end{array}$ & 4-in. CS & $\begin{array}{l}\text { Basalt: } 54.9 \mathrm{~m}(180 \mathrm{ft}) \\
\text { bgs Interbed: } 140.8 \mathrm{~m} \\
(462 \mathrm{ft}) \text { bgs }\end{array}$ \\
\hline 199-B2-14 & $21.6(71)$ & 23 Apr 2010 & Hanford & 4 in. SS & $\begin{array}{l}\text { Well plugged at } 22.9 \mathrm{~m} \\
(75 \mathrm{ft})\end{array}$ \\
\hline
\end{tabular}




\begin{tabular}{|c|c|c|c|c|c|}
\hline 199-B9-2 & $33.3(110)$ & 21 Apr 2010 & Hanford & 4-in. SS & \\
\hline 299-E33-340 & $99,7(327)$ & 19 Apr 2010 & $\begin{array}{l}\text { Hanford } \\
\text { Basalt }\end{array}$ & 4-in. SS & $\begin{array}{l}\text { Basalt: } 68.9 \text { m ( } 226.1 \\
\text { ft) bgs Interbed: } 93 \text { m } \\
(305 \mathrm{ft}) \text { bgs }\end{array}$ \\
\hline 299-E34-5 & $55.2(181)$ & $22 \operatorname{Mar} 2010$ & $\begin{array}{c}\text { Hanford } \\
\text { Near Basalt }\end{array}$ & 4-in. SS & $\begin{array}{l}\text { Basalt: } 58 \mathrm{~m}(190 \mathrm{ft}) \\
\text { bgs }\end{array}$ \\
\hline $699-28-30$ & $54(177)$ & 23 Mar 2010 & Hanford & 6 -in. SS & $\begin{array}{l}\text { Hanford } \\
\text { Cold Creek Units }\end{array}$ \\
\hline $699-31-17$ & $182.9(600)$ & 24/25 Mar 2010 & $\begin{array}{c}\text { Hanford } \\
\text { Cold Creek } \\
\text { Unit } \\
\text { Ringold } \\
\text { Basalt } \\
\end{array}$ & 4-in. PVC & $\begin{array}{l}\text { Basalt: } 169.2 \mathrm{~m} \mathrm{(555} \\
\text { ft) bgs }\end{array}$ \\
\hline $699-36-27$ & $43(141)$ & 23 Mar 2010 & & 6-in. CS & \\
\hline $699-40-33 B$ & $83.2(273)$ & 24 Mar 2010 & $\begin{array}{l}\text { Hanford } \\
\text { Ringold }\end{array}$ & 6-in. CS & $\begin{array}{l}\text { Basalt: } 84.7 \mathrm{~m}(278 \mathrm{ft}) \\
\text { bgs }\end{array}$ \\
\hline $699-49-21$ & $34.1(112)$ & 22 Mar 2010 & Hanford & 6 -in. CS & $\begin{array}{l}\text { Basalt: } 45.7 \mathrm{~m}(150 \mathrm{ft}) \\
\text { bgs }\end{array}$ \\
\hline $699-50-59$ & $52.1(171)$ & 22 Apr 2010 & $\begin{array}{l}\text { Hanford } \\
\text { Basalt }\end{array}$ & 4-in. SS & \\
\hline $699-52-55$ & $55.2(181)$ & 23 Apr 2010 & $\begin{array}{l}\text { Hanford } \\
\text { Basalt }\end{array}$ & 4-in. SS & \\
\hline 699-52-55B & $75(246)$ & 20 Apr 2010 & $\begin{array}{l}\text { Hanford } \\
\text { Basalt }\end{array}$ & 4-in. SS & $\begin{array}{l}\text { Measured top-of- } \\
\text { interbed }\end{array}$ \\
\hline $699-55-60 \mathrm{~A}$ & $65.5(215)$ & 22 Apr 2010 & Hanford & 8-in. CS & \\
\hline $699-57-83 C$ & $125.3(411)$ & 21 Apr 2010 & $\begin{array}{l}\text { Hanford } \\
\text { Ringold } \\
\text { Basalt }\end{array}$ & 4-in. CS & $\begin{array}{l}\text { Sledgehammer } \\
\text { source, loss of signal } \\
\text { below } 128 \mathrm{~m}(420 \mathrm{ft})\end{array}$ \\
\hline $699-61-62$ & $53.6(176)$ & 20 Apr 2010 & $\begin{array}{c}\text { Hanford } \\
\text { Basalt }\end{array}$ & 8-in. CS & \\
\hline $699-63-58$ & $39.3(129)$ & 20 Apr 2010 & $\begin{array}{l}\text { Hanford } \\
\text { Basalt }\end{array}$ & 8-in. CS & \\
\hline $699-65-83$ & $34.4(113)$ & 23 Apr 2010 & Hanford & 6-in. CS & \\
\hline & \multicolumn{5}{|c|}{ below ground surface } \\
\hline $\mathrm{cs}$ & \multicolumn{5}{|c|}{ carbon steel } \\
\hline PVC & \multicolumn{5}{|c|}{ polyvinyl chloride } \\
\hline SS & \multicolumn{5}{|c|}{ stainless steel } \\
\hline
\end{tabular}

\section{Equipment Procedures}

Surveys conducted under this investigation employed the check shot survey method as defined under ASTM D-7400-08 and followed the procedures and survey setup outlined in SGW-39020. The check shot method involves placing a seismic receiver (borehole geophone) at various depths in a well, and measuring the time for seismic energy to travel from an impulsive seismic source located on the ground surface to the borehole geophone. Measurements of the compressional-wave ( $\mathrm{P}$-wave) were conducted 
under this investigation, and an impulsive source such as a weight drop or sledgehammer blow are used to generate the seismic wave.

Figure 6 shows a schematic of a typical check shot setup and the resulting seismic shot-record format used during this survey. The shot point (sledgehammer position) is offset from the well point in order to reduce the interference from seismic waves propagating down the casing (tube-wave). Using an offset shot point allows the seismic energy to broadside the well at shallow depths and delay the arrival of the casing generated tube-wave until after the direct arrival (diagonal path from shot to receiver position). The seismic energy is recorded by three receivers housed in the downhole geophone as indicated for receivers 10 through 12 in the example shot record (lower left corner of Figure 6).

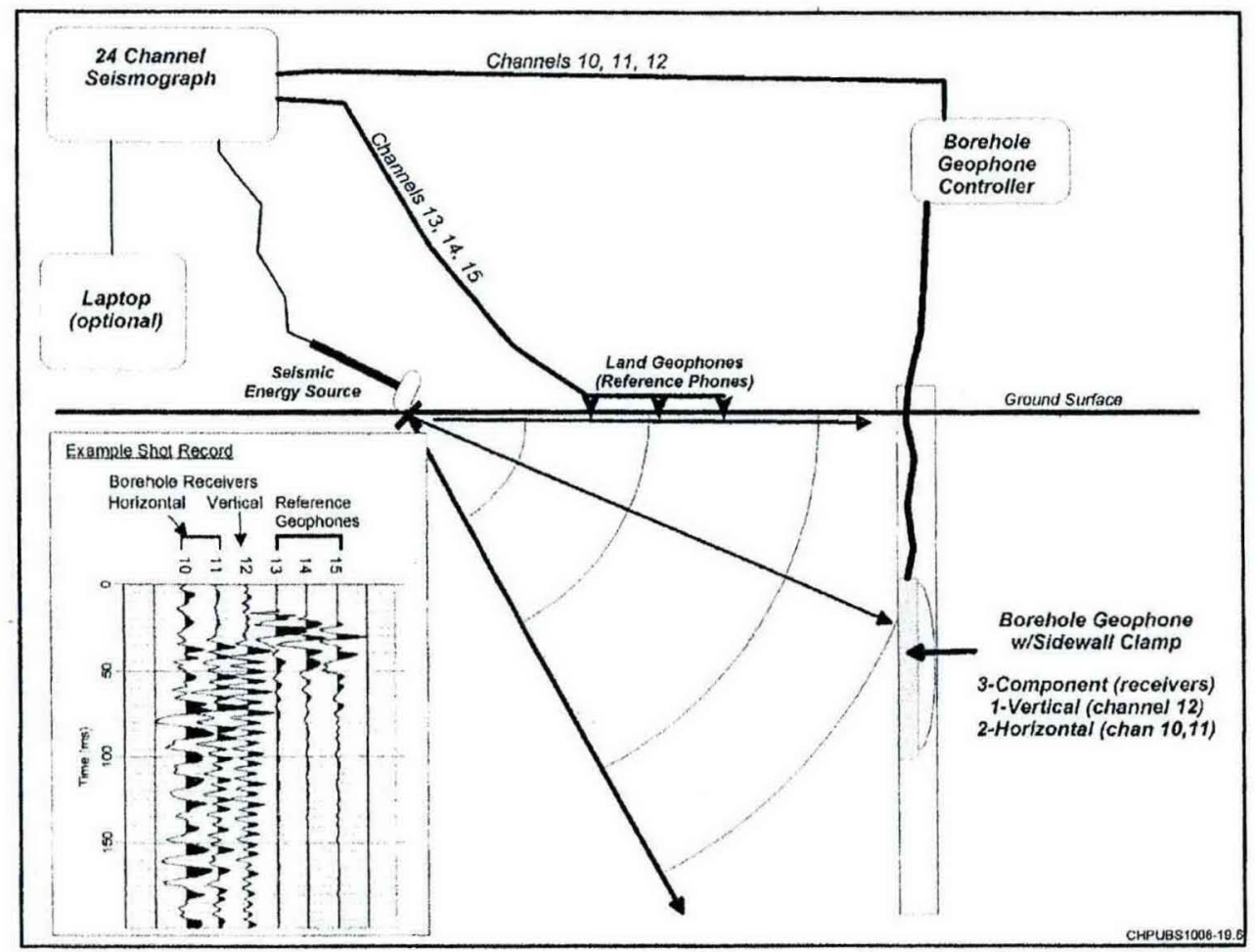

Figure 6. Check Shot Survey Setup and Example Shot Record

\subsubsection{Equipment}

Both the Geometrics' ${ }^{\circledR}$ StrataView and Geode 24-channel engineering seismographs were used to record the seismic data during the three survey rounds (Figure 7).

Data were recorded using a 0.125 -millisecond (ms) sample interval and record lengths of 256 to $512 \mathrm{~ms}$ ( $1 / 4$ to $1 / 2$ second). Data were recorded unfiltered as site conditions did not exhibit noise levels (powerline, vehicular, or other sources) that could not be overcome by the energy source. A pre-trigger recording window of $10 \mathrm{~ms}$ was used to help identify noise conditions during the survey. Both seismographs allow for seismic signal capture and enhancement through a wide dynamic range (ability to detect low amplitude signals) and signal stacking capabilities. Signal stacking involves repeating a shot point one or more times for a given shot-receiver geometry in order to increase the amplitude of the resulting seismic signal and to suppress transient signals (noise) resulting from infrastructure (e.g., pumps) and vehicular activity. 


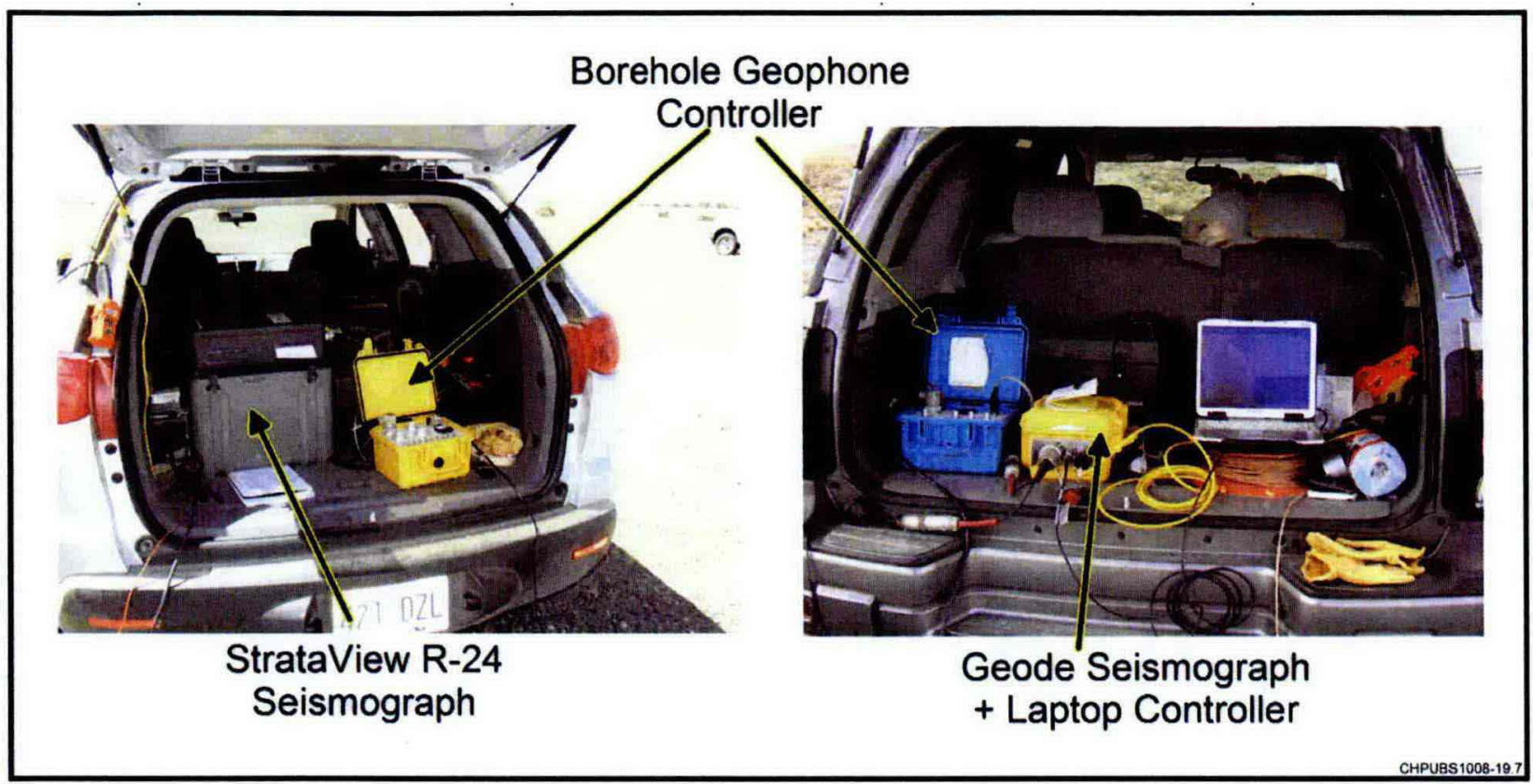

Figure 7. Borehole Geophone Controller

A Geostuff model BHG-2 receiver was used as the borehole geophone (Figure 8). The BHG-2 is a threecomponent (two horizontal and one vertical) sidewall clamping sonde employing $40-\mathrm{Hz}$ receiver elements. The vertical component was recorded on channel 12, and the horizontal components were on channels 10 and 11. Conventional land geophones were used as reference receivers to ensure consistent shot timing during the survey. Seismic energy detected by reference geophones, Mark Products model L12 , was recorded on channels 13,14 , and 15 for the $1.5-\mathrm{m}(5-\mathrm{ft}), 3-\mathrm{m}(10-\mathrm{ft})$, and $4.5-\mathrm{m}(15-\mathrm{ft})$ offsets from the shot point.

For the FY 2008 and FY 2010 surveys, the seismic energy source was a 7.3-kg (16-lb) sledgehammer striking a $0.4-\mathrm{m}(1.25-\mathrm{ft})$ diameter steel plate. For most cases, a stack count (signal enhancement) of two to three repeat strikes were required to detect the propagating seismic wave in the upper $45.7 \mathrm{~m}(150 \mathrm{ft})$ of the well; below $45.7 \mathrm{~m}(150 \mathrm{ft})$ in depth, stack counts ranged from 3 to 15 repeat shots, with progressively greater stack counts for greater depths. A $226.8 \mathrm{-kg}(500-\mathrm{lb})$ trailer-mounted accelerated weight drop source was used during the FY 2009 surveys with stack counts ranging from 1 to 4 (see Figure 9).

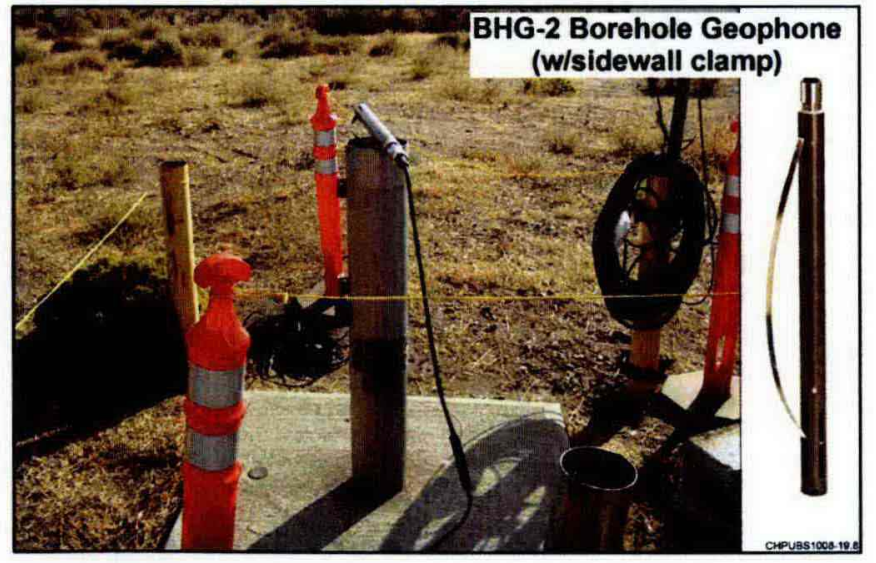

Figure 8. Geostuff Model BHG-2 Borehole Geophone (with Sidewall Clamp) 


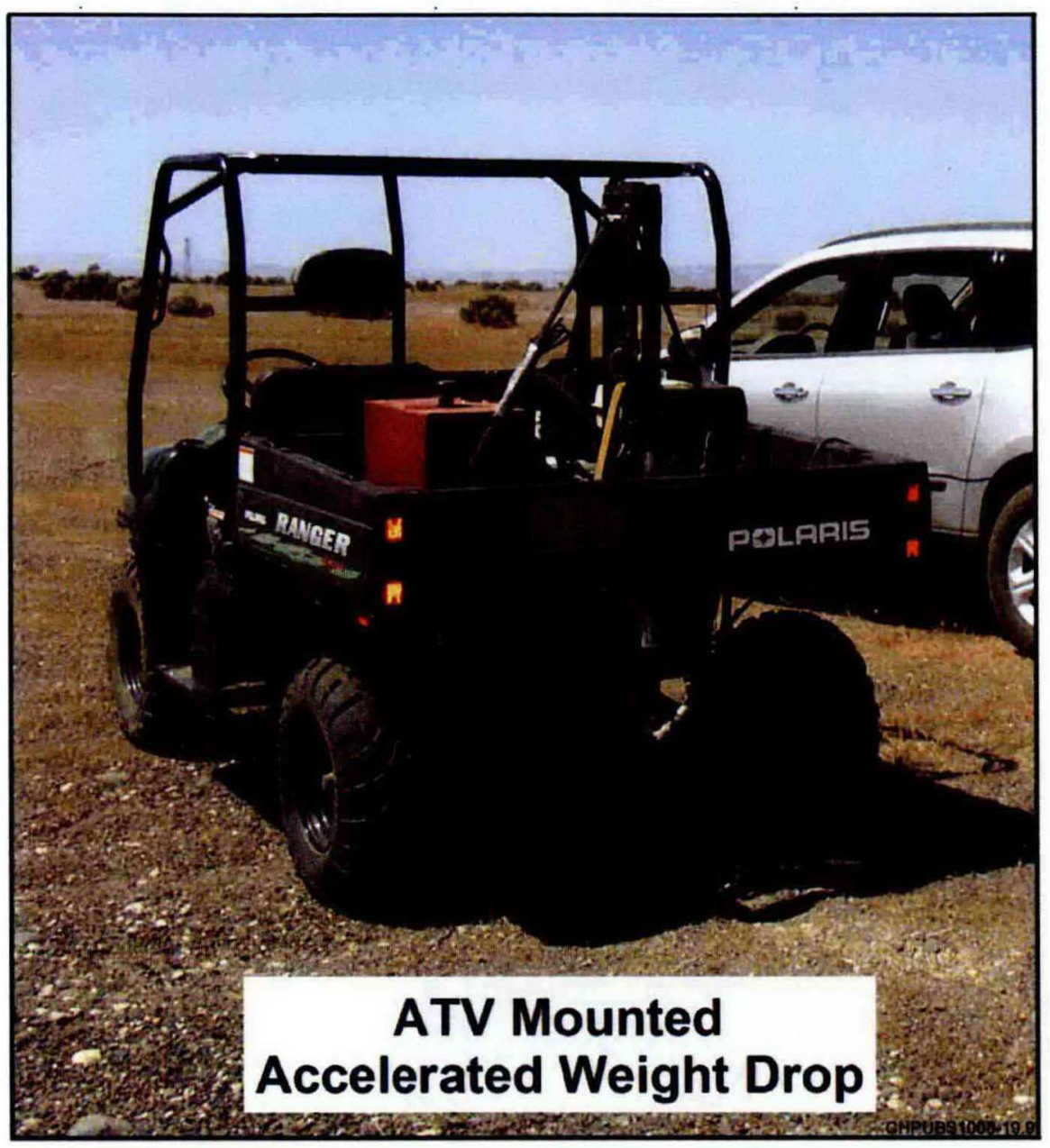

Figure 9. ATV Mounted Accelerated Weight Drop

Seismic signal proved difficult to detect and record in Wells 299-E28-6, 699-31-17, and 699-57-83C. For 299-E28-6, stack counts of 50-60 with the sledgehammer did not produce seismic signal below $88.4 \mathrm{~m}$ (290 ft), and the loss of seismic signal in Well 299-E28-6 is attributed to well construction rather than the underlying geology, where the construction resulted in poor coupling of the borehole geophone (or well)

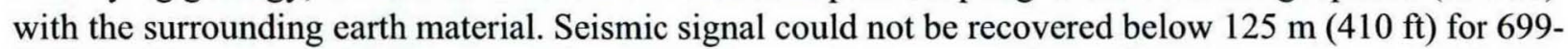
$37-83 \mathrm{C}(15.2 \mathrm{~m} \mathrm{[50} \mathrm{ft}$ ] below top-of-basalt). Extreme wind gusts and possible casing earth material coupling interfered with surveys in Well 699-31-17. Advanced filtering, though, allowed recovery of seismic signal to $182.9 \mathrm{~m}(600 \mathrm{ft})$ in depth. All three surveys used a sledgehammer source, and it is likely that an accelerated weight drop like that shown in Figure 9 would overcome the signal attenuation.

Raw, unfiltered signals acquired in the check shot survey were stored directly on either the seismograph or laptop hard drive in the SEG-2 industry standard format, and transferred to an auxiliary storage drive and then the Hanford Local Area Network at the end of each day for later analysis. Each stored shot record contains six traces of seismic data (see example shot-record in Figure 6). Shot data were composited by recording channel and receiver depth into raw shot records showing the change in seismic signal with depth. Filtered and unfiltered plots of the raw shot records are shown in Figure A1-through Figure A29 (Appendix A). 


\subsubsection{Procedures}

Survey procedures followed steps defined in SGW-39020 and methodology specified in ASTM D-740008. For each check shot survey, the shot point was offset from the well casing, reference geophones were implanted at fixed distances from the shot point, and the borehole geophone moved down the borehole in 3-m (10-ft) increments. Deviations from the 3-m (10-ft) interval occur in wells 699-49-21, 699-40-33B, and 699-60-59. The first two wells used a $1.5-\mathrm{m}(5-\mathrm{ft})$ interval in an attempt to refine Hanford units, and

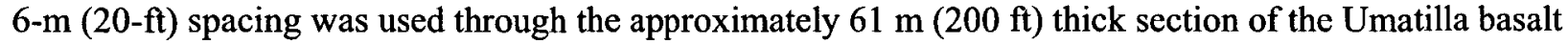
in Well 699-60-59.

Shot points were offset from $3 \mathrm{~m}$ to $20 \mathrm{~m}$ (10 ft to- $66 \mathrm{ft}$ ) from the well point in order to reduce the effect of tube-waves (seismic energy travelling up and down the well's casing). The three reference geophones were offset $1.5 \mathrm{~m}(5 \mathrm{ft}), 3 \mathrm{~m}(10 \mathrm{ft})$, and $4.5 \mathrm{~m}(15 \mathrm{ft})$ from the shot point and were installed in-line between the shot and well. Two shot point locations (near and far) were used for wells 699-26-15C, 69931-17, 699-50-59, 699-55-60A, and 699-57-83C in order to suppress tube-waves. For Well 699-26-15C, the tube-wave is readily identifiable as a high-velocity (quick) signal that departs from the direct wave

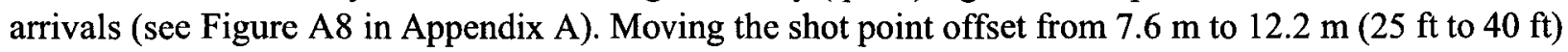
results in a dramatic change in the tube-wave's arrival (delayed due to the increased shot-to-well distance) without negatively impacting the direct-wave (desired signal) travel time.

Pre-survey checks included verifying the operation of the sidewall clamping mechanism, the ability of the borehole geophone to detect a seismic signal while at the ground surface, and ability of the seismograph to trigger when the shot was triggered (sledgehammer impacting the strike plate). An ambient noise record was recorded at the beginning of each survey with the borehole geophone clamped near the top of the well's casing.

A pre-survey radiation (RAD) screen was conducted, and the well only entered if no RAD contamination was detected. Post survey, both the downhole geophone and cable were RAD wiped as they were removed from the well. The wipe, cable, and borehole geophone were screened for RAD contamination. RAD contamination was not detected during the surveys.

\section{Analysis}

Check shot data were analyzed using the following general steps:

1. Sort data into shot gathers based on receiver type. The result is six shot gathers per well survey consisting of vertical, two horizontal, and three reference (land-surface) components. The number of data channels per shot gather equals the number of depth points acquired for each well. Sorted data are stored in the Kansas Geological Survey modified SEG-Y seismic format (KGS, 1991).

2. Pick arrival time of the direct $\mathrm{P}$-wave at each reference geophone and determine timing correction (if any).

- Determine arrival time for each reference geophone and shot combination.

- Determine reference arrival times for each of the three reference receivers. These values are either the mode (most common arrival time) or an average of the median and mean values if the data are not uni-modal.

- Determine shot-timing variations based on the departure from the reference arrival time. Calculation is performed by subtracting the onset arrival from the reference arrival. 
- Calculate a per-shot correction value based on an average of the departure for all three reference receivers.

3. Pick arrival-time of the P-wave at each borehole geophone depth point.

- Low-pass and band-pass digital filtering was required to enhance the first arriving seismic signal.

- Arrival time picks were based on both the unfiltered and filtered data.

4. Apply shot-timing corrections (if any) to the borehole arrival times.

- Determine mode (most frequent) of arrival times for each reference geophone, or average the median and mean values if a mode cannot be determined.

- Calculate departure (delta-time) from the mode.

- Adjust shot point times based on departure (correct to mode).

5. Correct arrival time for "slant-path" effects due to the shot point being offset from the borehole.

- Compute average velocity from shot point to borehole geophone depth-point.

- Use the average velocity to compute a theoretical vertical travel time to this depth point.

- The previous two steps are functionally equivalent to the cosine factor used in PNNL-16559.

6. Determine interval velocities for the corrected arrival time data.

- Compute estimates of the interval velocity from point-to-point slope changes and running leastsquares line-fits of $3,5,7$, and 9 points. Also, perform automated forward and reverse scans to find significant breaks in velocities.

- Compare the interval velocity estimates from the previous step with known changes in lithology and observed slope changes on the travel time data.

- Manually pick changes in velocity based on observed slope changes, using both the velocity estimates and lithology as a guide.

Shot timing variations are primarily due to subtle changes in the shot point, either caused by slight changes in position of the plate (or impact point), or to differential compaction of the underlying sediment. In some cases, repeated sledgehammer impacts create a shallow depression in the ground surface, which slightly changes the shot receiver geometry. Figure 10 shows the shot records and arrival

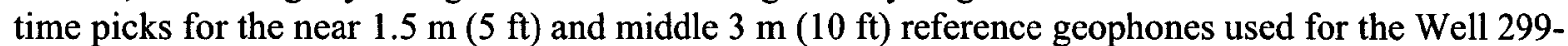
E34-7 check shot survey. Picked arrivals for traces 1 through 6 and 21 deviate from the near uniform time-picks between traces 8 and 20; thus, arrival times for shot points corresponding to these traces will need to be adjusted.

Timing corrections are calculated on a per-shot basis and computed using the difference between an empirically-determined reference arrival time and the arrival time pick for each reference receiver trace. The reference arrival time value is determined from the mode (most common arrival time), or from an average of the median and mean values if a mode cannot be determined. Per-shot timing corrections are based on an average of the correction values from all the three reference phones and applied on a traceby-trace basis. For example, the amount of deviation for each of the seven traces identified in Figure 10 will be used to calculate timing corrections for each of the corresponding shot points with the correction equaling the amount of time-shift required to bring in-line with traces 8 through 20 . 


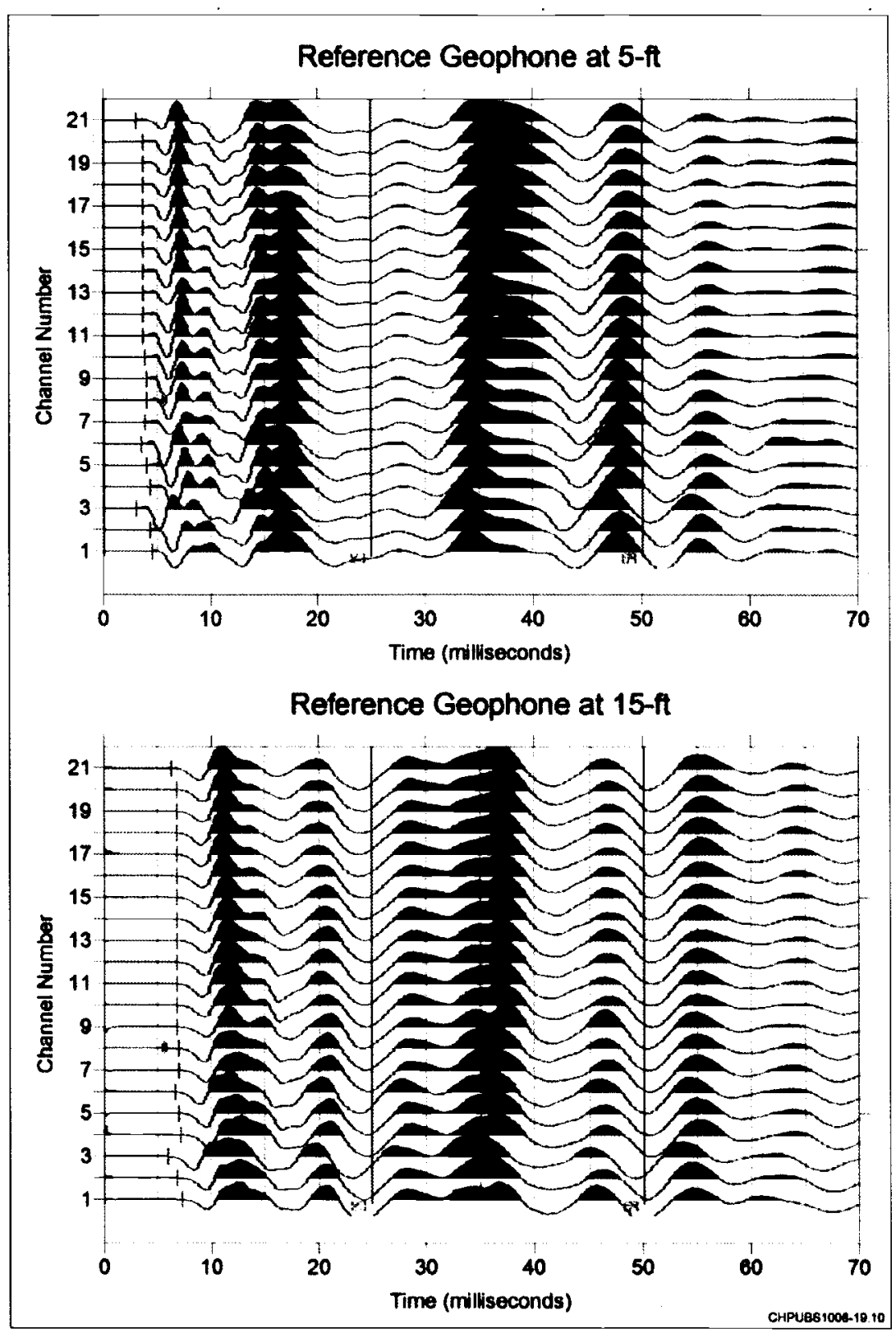

Figure 10. Well 299-E34-7: Reference Geophone Arrivals

Travel time picking focused on determining the first break (departure from zero amplitude) and used the commercial software SIPIK (Rimrock Geophysics, 1992). The time picking software employs zero-phase Sine-Butterworth low- and band-pass filters to reduce noise and/or enhance the seismic signal without destroying the original data. For some cases, a real-time convolution function using a boxcar operator was also employed to convert the first break into a peak (or trough) in order to aid in the identification of the first arrival. Time picks were initially based on the raw, unfiltered data and subsequently modified based on filtered signal. Quick toggling between the filtered and unfiltered shot records was conducted to ensure that the arrival time pick was not impacted by any filtering lag (time offset). Time picking was conducted on the sorted seismic data, which allowed visual tracing of the arrival of seismic signal with depth. The ability to trace the seismic signal from depth point to depth point (or from top of well to bottom) affords greater confidence in the resulting time pick data set. 
Raw and filtered shot-records for the wells surveyed in September 2008, June 2009, and March and April of 2010 are shown in Figure A1 through Figure A29 (Appendix A). The data are displayed by trace number and travel time, with depth increasing from top-to-bottom of each plot. A heavy blue trace line is used to denote where the start of the seismic signal is interpreted, and light-blue colored dots indicate the travel time pick.

Measured travel times have to be corrected back to a true vertical travel time because the energy source was offset horizontally from well point (see Figure 6). The average velocity along the slant path (shot-toreceiver) is computed, and this average velocity is then used to compute a theoretical vertical travel time to the depth point. The following equations are used:

$$
\begin{array}{ll}
\mathbf{V}_{\text {avg }} & =\left(d^{2}+s^{2}\right)^{1 / 2} / t_{s} \\
t_{v} & =d / V_{a v g}=t_{s} \star d /\left(d^{2}+s^{2}\right)^{1 / 2}
\end{array}
$$

where:

$$
\begin{array}{ll}
\mathrm{d} & =\text { depth to borehole geophone } \\
\mathrm{s} & =\text { shot point offset from borehole } \\
\mathrm{t}_{\mathrm{s}} & =\text { measured travel time (corrected for shot timing) } \\
\mathrm{V}_{\text {avg }} & =\text { average velocity } \\
\mathrm{t}_{\mathrm{v}} & =\text { corrected travel time }
\end{array}
$$

Interval velocities are determined by fitting least-squares lines on segments (breaks in slope) of the observed travel time with depth information. Figure 11 shows a typical travel time with depth plot and the resulting velocity with depth model. Significant changes in slope on the time depth plot are interpreted at $4.6 \mathrm{~m}(15 \mathrm{ft}), 12.2 \mathrm{~m}(40 \mathrm{ft}), 16.5 \mathrm{~m}(54 \mathrm{ft}), 23.5 \mathrm{~m}(77 \mathrm{ft})$, and $32 \mathrm{~m}(105 \mathrm{ft})$ in depth and marked by the vertical dashed red lines. Least-squares line fits for the $4.6 \mathrm{~m}$ to $12.2 \mathrm{~m}(15 \mathrm{ft}$ to $40 \mathrm{ft})$ and $16.5 \mathrm{~m}$ to 23.5 $\mathrm{m}(54 \mathrm{ft}$ to $77 \mathrm{ft})$ depth intervals are shown as dashed blue lines with the resulting seismic velocity (change in depth divided by change in time). There will always remain some judgment when partitioning the time-depth information into discrete velocity layers, especially in unconsolidated sedimentary sequences where velocity contrasts may be low resulting in a relatively smooth change in travel time with depth.

A set of automated least-squares line fits, ranging from 3-point to 9-point running sequences, are used to reduce some of the potential bias when interpreting the time-depth graph. This initial set of velocity estimates is compared and adjusted using the geology observed for the well. Figure 12 shows results of the automated velocity scans for wells $299-\mathrm{E} 32-10,699-49-57 \mathrm{~B}$, and 699-52-55B. In each case, velocity estimates are determined using point-to-point (straight-line slope) and a suite of running least-squares line-fits, each of $3,5,7$, and 9 points. In addition, two additional velocity-break (slope-change) estimates are made using automated forward and reverse scans. Small scale deviations in travel time generally result in large swings in velocity for the point-to-point and 3-point (IntVel-P and IntVel-3), whereas the 7- and 9-point least-squares line-fits (IntVel-7 and IntVel-9) tend to produce overly smooth results which don't capture important velocity information at the shallow and deep ends of the time-depth curve. The final velocity (heavy blue line) represents a compromise solution that attempts to capture some of the subtle velocity detail and yet remain consistent with the underlying geology. 


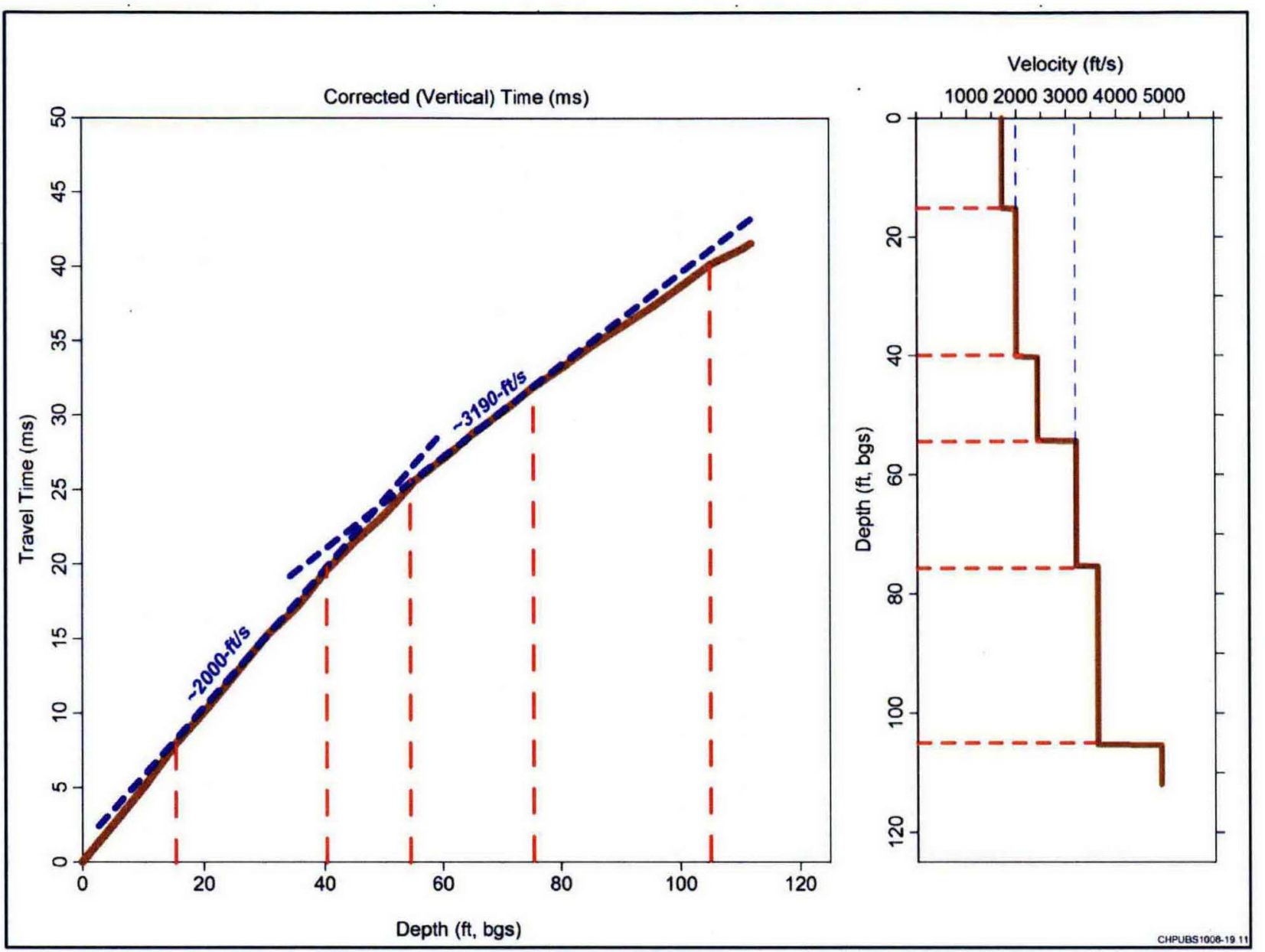

Figure 11. Converting Time-Depth to Velocity

\section{Results}

Figure 13 through Figure 41 show the calculated vertical travel time, interval velocity, available lithologic information, and natural gamma log data for the 29 wells. Driller's log descriptions were obtained from the Hanford Well Information System as either well summary or drilling log description data sets. Geologic information was obtained from the in-house Pacific Northwest National Laboratory-Hanford maintained TOPS data set (geologic tops) as well as where identified on the driller's logs. Natural gamma logs were obtained from the Hanford Environmental Information System database.

\subsection{Well 299-E26-08}

Well 299-E26-08 is located in the 200 East Area about $45.7 \mathrm{~m} \mathrm{(150} \mathrm{ft)} \mathrm{east} \mathrm{of} \mathrm{and} \mathrm{near} \mathrm{the} \mathrm{middle} \mathrm{of} \mathrm{the}$ FY 2008 Canton Road seismic profile (SGW-39675) (see Figure 2). The well is located on a berm covering a waste transfer pipe with surface soils comprised primarily of sand. Pertinent information regarding the travel time to the top-of-Ringold and Basalt, as well as basalt inter-bed information, is potentially afforded by the well. Total survey depth was $121.2 \mathrm{~m}(400 \mathrm{ft})$ below ground surface (bgs). 


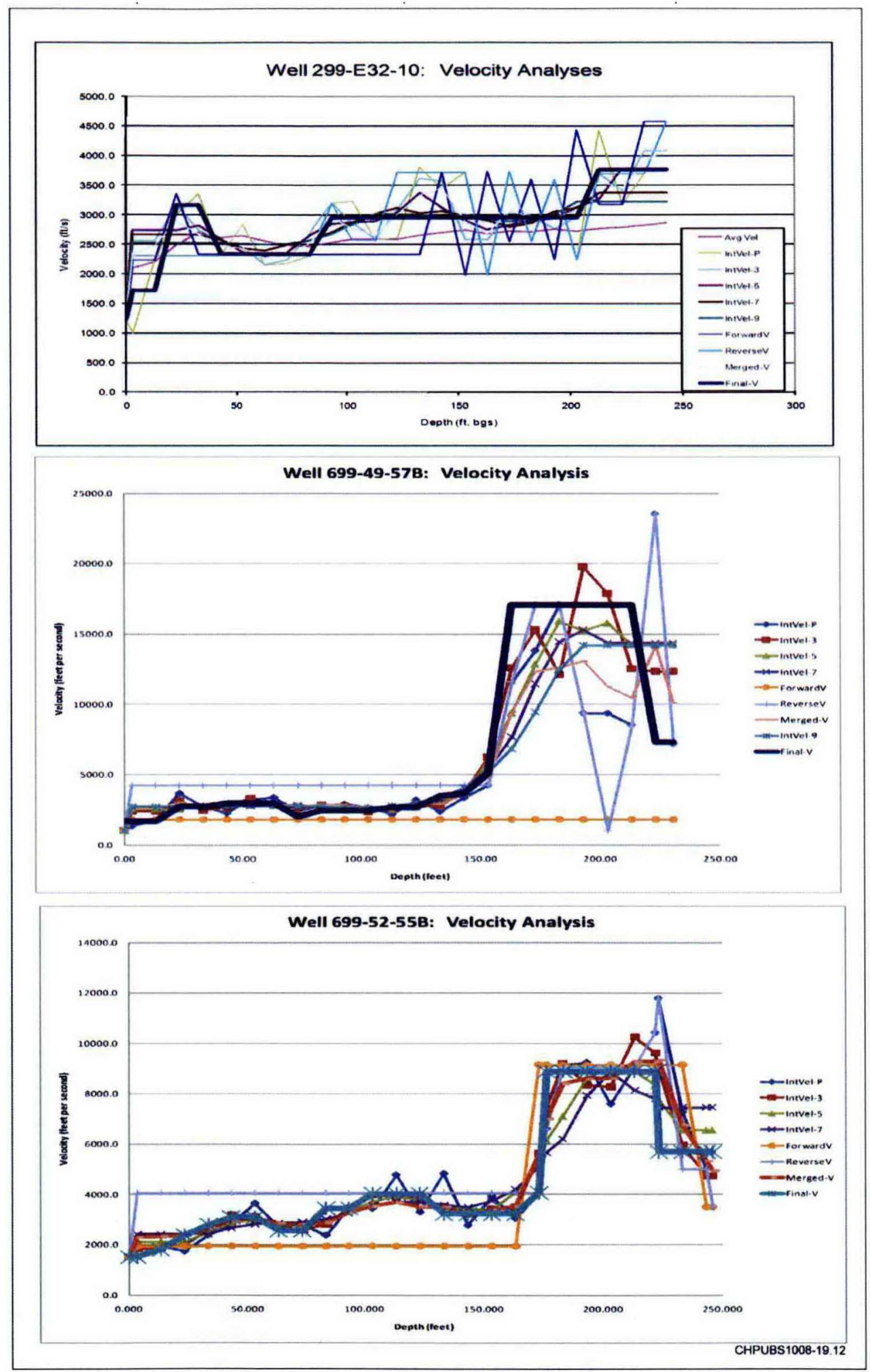

Figure 12. Example Velocity Scans 
Figure 13 shows the resulting travel time measurements and estimated velocity, along with the natural gamma log, geology, and driller's description. Travel times appear to be unnaturally fast in the $15.2 \mathrm{~m}$ to $45.7 \mathrm{~m}(50 \mathrm{ft}$ to $150 \mathrm{ft})$ depth interval and result in estimating a zone of extreme high velocity in the $30 \mathrm{~m}$ to $48.8 \mathrm{~m}(100 \mathrm{ft}$ to $160 \mathrm{ft})$ depth interval. Above $15.2 \mathrm{~m}(50 \mathrm{ft})$ in depth, velocities are estimated to range from $448.1 \mathrm{~m} / \mathrm{s}$ to $1,127.8 \mathrm{~m} / \mathrm{s}(1,470 \mathrm{ft} / \mathrm{s}$ to $3,700 \mathrm{ft} / \mathrm{s})$. The velocity estimate for basalt inter-bed zone is $\sim 2,011.7 \mathrm{~m} / \mathrm{s}(\sim 6,600 \mathrm{ft} / \mathrm{s})$, which is consistent with previously published results for inter-bed velocities underlying the Hanford Site (PNNL-16559). Velocity estimates for the basalt units range from 2,377.4 $\mathrm{m} / \mathrm{s}$ to $3,048 \mathrm{~m} / \mathrm{s}(7,800$ to $10,000 \mathrm{ft} / \mathrm{s})$.

One possible explanation for the unnatural high velocities is that the seismic energy traveled through some combination of the well casing and transfer pipe (within soil berm), and not directly through the sedimentary units. Casing size and well construction, however, cannot be the sole explanation as the similarly cased and constructed Well 299-E28-6 did not produce unreasonably high check shot velocities.

\subsection{Well 299-E28-06}

Well 299-E28-06 is located in the 200 East Area immediately to the southeast of the intersection of Baltimore Rd and $7^{\text {th }}$ Street, and time depth information was obtained in the well used to support the interpretation of the corresponding FY 2008 seismic profiles (see Figure 2). The well is in an open area with primarily gravel and sand at the surface. Information regarding the travel time through Hanford sediments is provided by the check shot survey. Basalt was not encountered during the installation of this

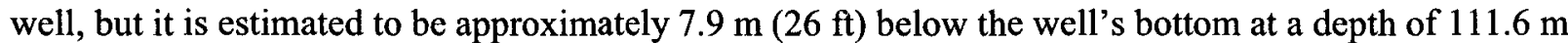
$(366 \mathrm{ft})$ bgs. Total well depth is approximately $103.6 \mathrm{~m}(340 \mathrm{ft}) \mathrm{bgs}$, but the check shot survey was limited to approximately $88.4 \mathrm{~m}(290 \mathrm{ft})$ in depth due to severe attenuation of the seismic signal below this depth.

Figure 14 shows the resulting travel time measurements and estimates of velocity for this well, and the shot record and travel time picks are shown in Figure A2. Estimated arrival times to the predicted top-ofbasalt are shown as dashed lines and were derived from sediment velocities obtained from check shot surveys in Well C4562 (Northland Geophysical, 2004).

The velocity structure shows a general increase with depth, starting near $304.8 \mathrm{~m} / \mathrm{s}(1,000 \mathrm{ft} / \mathrm{s})$ in the upper $1.5 \mathrm{~m}$ to $3 \mathrm{~m}(5 \mathrm{ft}$ to $10 \mathrm{ft})$ and ending at $\sim 1,066.8 \mathrm{~m} / \mathrm{s}(\sim 3500 \mathrm{ft} / \mathrm{s})$ at $88.34 \mathrm{~m}(290 \mathrm{ft})$ in depth. Significant changes in velocity occur at approximately $7.6 \mathrm{~m}(25 \mathrm{ft})$ in depth $(-579.1 \mathrm{~m} / \mathrm{s}$ to $833 \mathrm{~m} / \mathrm{s}$ $[\sim 1,900 \mathrm{ft} / \mathrm{s}$ to-2,700 ft/s]) and at $61 \mathrm{~m}(200 \mathrm{ft})$ in depth $833 \mathrm{~m} / \mathrm{s}$ to $1,097.3 \mathrm{~m} / \mathrm{s}(2,700 \mathrm{ft} / \mathrm{s}$ to $3,600 \mathrm{ft} / \mathrm{s})$. The upper change likely corresponds to a change from gravel/cobbles to sands, whereas the lower change possibly indicates an increase in silt content.

\subsection{Well 299-E32-10}

Well 299-E32-10 is located near the northwest corner of the 200 East Area along $12^{\text {th }}$ Street (Figure 2). The well is in an open area with primarily gravel and sand at the surface. Check shot surveys in this well provide travel time measurements through the Hanford units, to near the top-of-Basalt, and are used to support interpretation of the FY 2008 seismic profile along $12^{\text {th }}$ Street. Basalt was encountered at

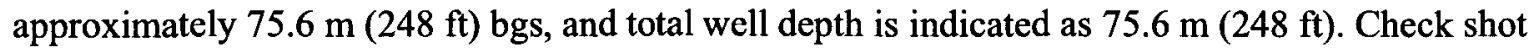
surveying was completed to approximately $74.1 \mathrm{~m}(243 \mathrm{ft}) \mathrm{bgs}$. 


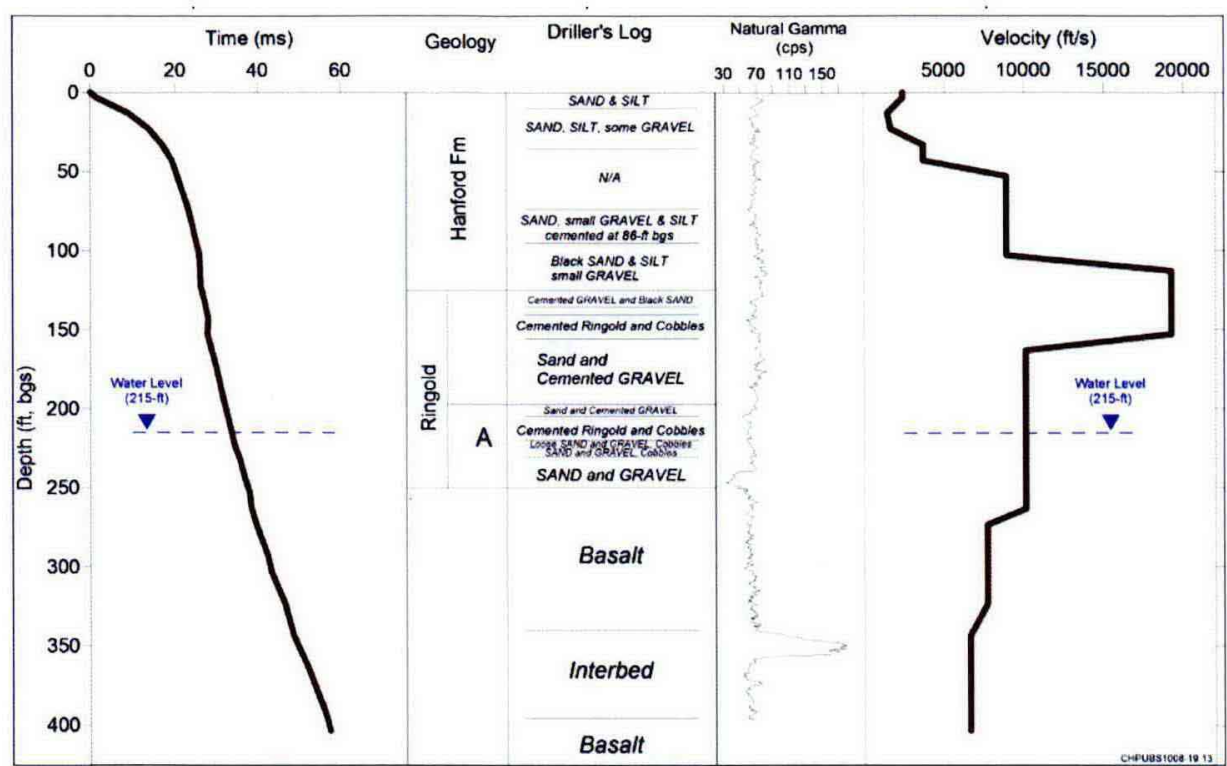

Figure 13. Check Shot Survey Results for Well 299-E26-08

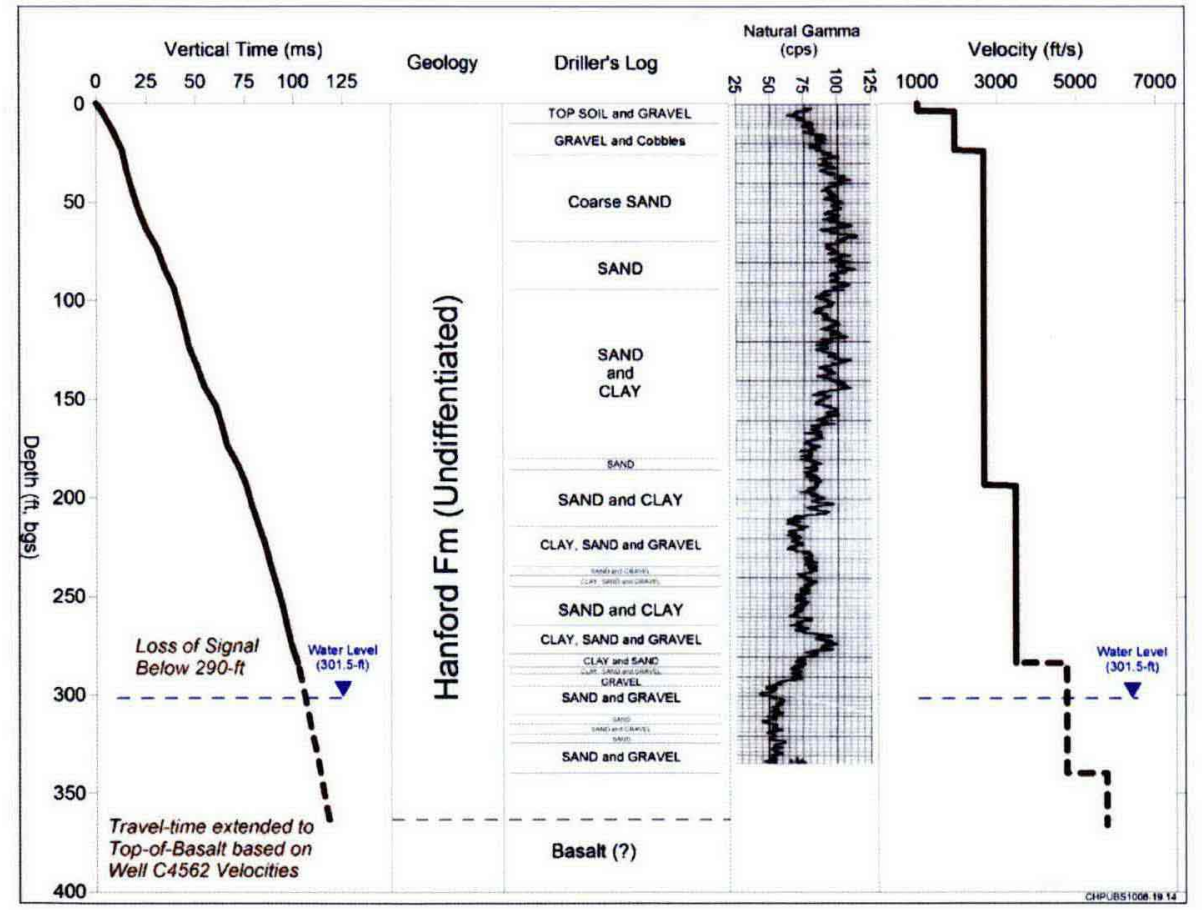

Figure 14. Check Shot Survey Results for Well 299-E28-06

Travel time and estimated velocities are shown in Figure 15, with significant breaks in travel time slope occurring at approximately $4 \mathrm{~m}(13 \mathrm{ft}), 10.7 \mathrm{~m}(35 \mathrm{ft}), 25.9 \mathrm{~m}(85 \mathrm{ft})$, and $61.9 \mathrm{~m}(203 \mathrm{ft})$ in depth (see Figure A3 in Appendix A for shot record). These breaks in slope are interpreted to represent overall changes in the subsurface velocity. A zone of relatively high velocity (for shallow depth Hanford sediments) occurs in the $4 \mathrm{~m}$ to $10.7 \mathrm{~m}$ (13 ft to $35 \mathrm{ft}$ ) depth range and is possibly correlative with a

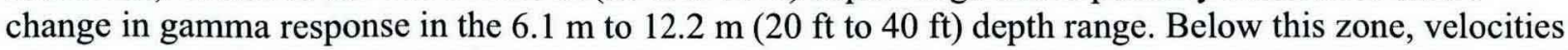
of approximately $701 \mathrm{~m} / \mathrm{s}(2,300 \mathrm{ft} / \mathrm{s})(10.7 \mathrm{~m}$ to $25.9 \mathrm{~m}$ [35 ft to $85 \mathrm{ft}]), 91.4 \mathrm{~m} / \mathrm{s}(3,000 \mathrm{ft} / \mathrm{s}) 25.9 \mathrm{~m}-60.1$ $\mathrm{m} 85-200 \mathrm{ft}$, and $1,128 \mathrm{~m} / \mathrm{s}(3,700 \mathrm{ft} / \mathrm{s})(61+\mathrm{m}[200+\mathrm{ft}])$ are estimated for the remainder of the well. 


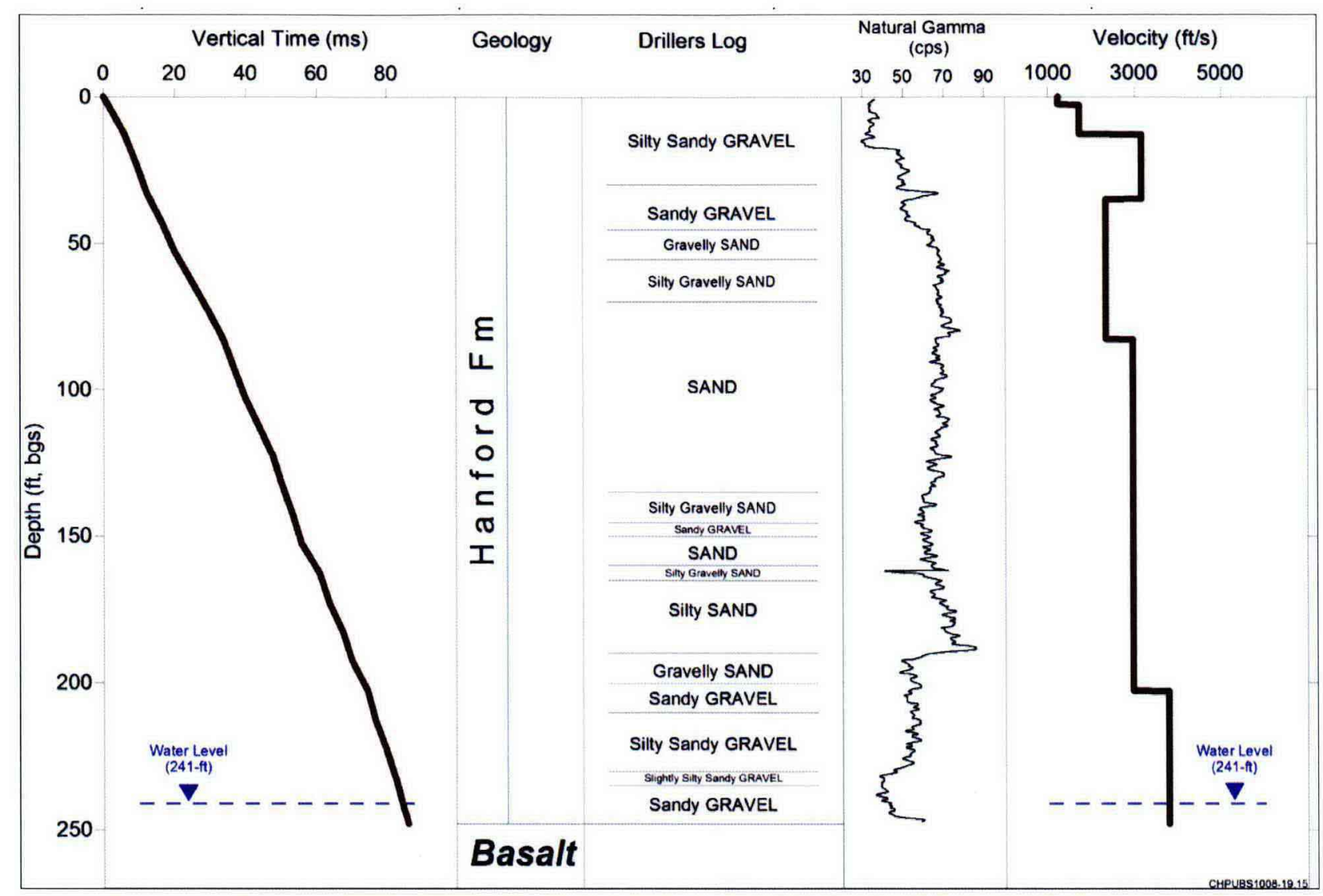

Figure 15. Check Shot Survey Results for Well 299-E32-10

The velocity increase at $61.9 \mathrm{~m} / \mathrm{s}(203 \mathrm{ft})($ from $91.4 \mathrm{~m} / \mathrm{s}$ to $1,128 \mathrm{~m} / \mathrm{s}[3,000 \mathrm{ft} / \mathrm{s}$ to $3,700 \mathrm{ft} / \mathrm{s}])$ appears to be consistent with a sharp decrease in the gamma-log response (slightly higher and near $57.9 \mathrm{~m} / \mathrm{s}$ [190 ft] bgs). It is not clear, however, whether or not the gamma-log change is geologic or well-construction related. Well construction records indicate that the well was drilled with a $27.3-\mathrm{cm}(10.75-\mathrm{in}$.) temporary casing to approximately $49.4 \mathrm{~m}(162 \mathrm{ft}) \mathrm{bgs}$, and a telescoping $22-\mathrm{cm}(8.65-\mathrm{in}$.) temporary casing was extended to bottom $75.6 \mathrm{~m}$ (248 ft). A 10.2-cm (4-in.) stainless steel casing was installed with a $6 \mathrm{~m}(20$

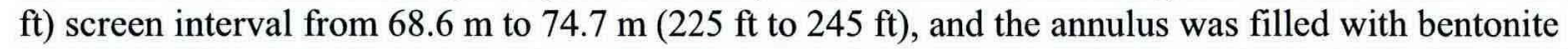
crumbles. The water level at the time of well construction was approximately $70.4 \mathrm{~m}(231 \mathrm{ft})$ bgs and is currently $73.5 \mathrm{~m}(241 \mathrm{ft}$ ) bgs (lower than the change in gamma log but unknown at time of logging).

\subsection{Well 299-E34-07}

Well 299-E34-07 is locate near the northeast corner of the 200 East Area approximately $396.2 \mathrm{~m}(1,300$ $\mathrm{ft}$ ) south of $12^{\text {th }}$ Street and $198.1 \mathrm{~m}(650 \mathrm{ft})$ west of Canton Rd (Figure 2). The well is in an open area with primarily gravel at the surface. Check shot surveys measured the travel time through Hanford sediments to near the top-of-basalt. Basalt was encountered at approximately $62.5 \mathrm{~m} \mathrm{(} 205 \mathrm{ft}$ bgs) during

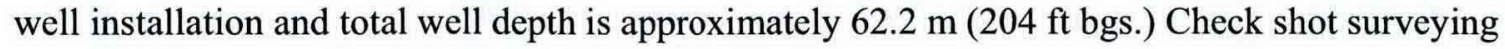
completed to approximately $61.6 \mathrm{~m}(202 \mathrm{ft})$ in depth.

Travel time measurements and estimates of velocity are shown in Figure 16 along with the natural gamma

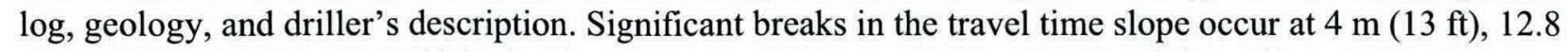
$\mathrm{m}(42 \mathrm{ft})$, and $34.4 \mathrm{~m}(113 \mathrm{ft})$ in depth and represent changes in the velocity of the sediments (see Figure A4 for shot record). The upper $4 \mathrm{~m}(13 \mathrm{ft})$ is estimated at approximately $457.2 \mathrm{~m} / \mathrm{s}(1,500 \mathrm{ft} / \mathrm{s})$ in velocity, 
with velocity increasing to $\sim 774.2 \mathrm{~m} / \mathrm{s}(\sim 2,540 \mathrm{ft} / \mathrm{s})(4 \mathrm{~m}[13 \mathrm{ft}]$ to $12.8 \mathrm{~m}[42 \mathrm{ft}]), \sim 1,007.4 \mathrm{~m} / \mathrm{s}(\sim 3,305$

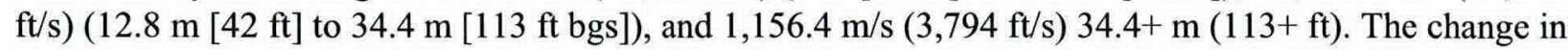
velocity from $1,007.4$ to $1,156.4 \mathrm{~m} / \mathrm{s}(3,305$ to $3,794 \mathrm{ft} / \mathrm{s})$ coincides with the Hanford $\mathrm{H} 2$ to $\mathrm{H} 3$ geologic boundary.

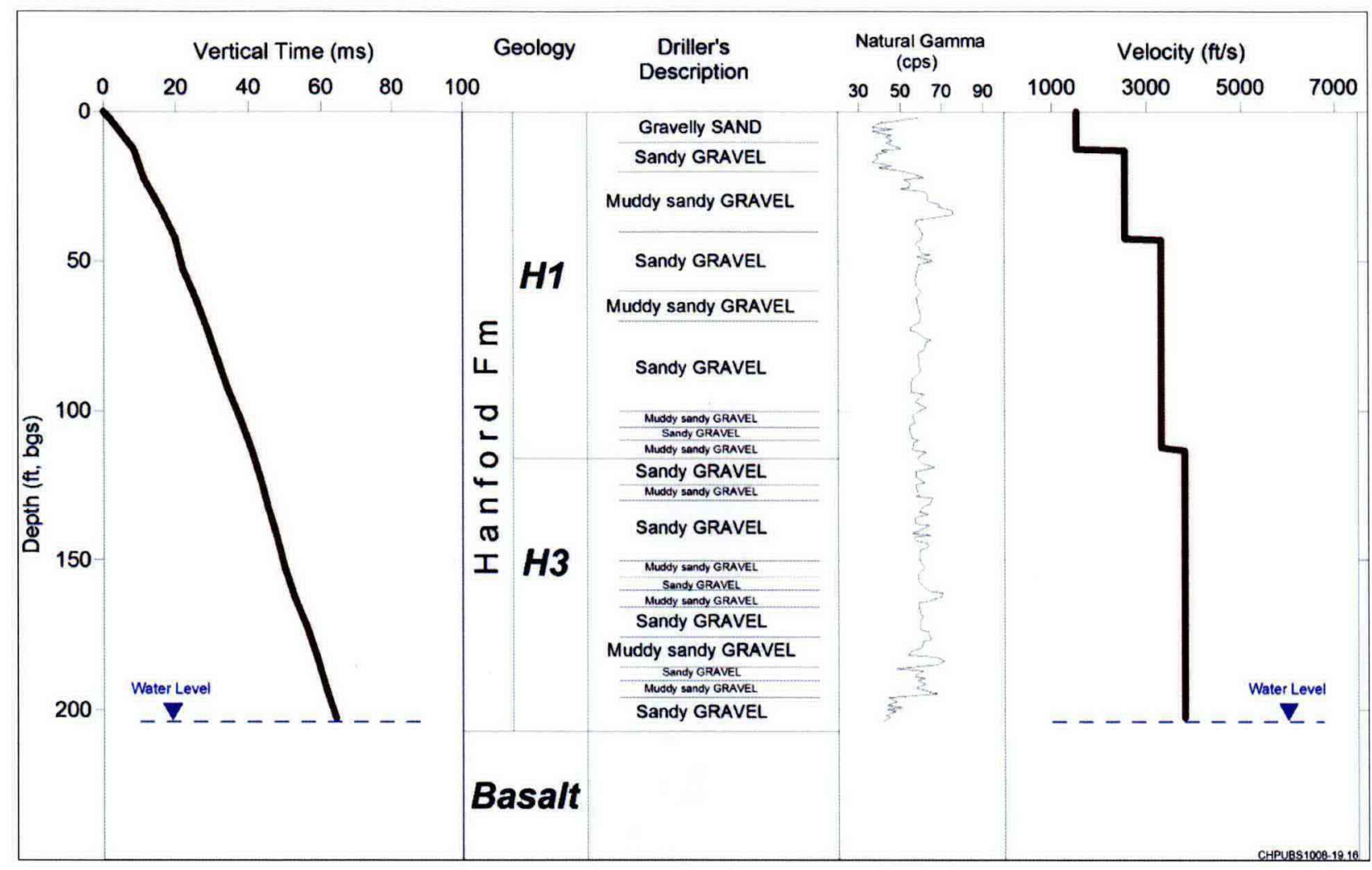

Figure 16. Check Shot Survey Results for Well 299-E34-07

\subsection{Well 699-37-47A}

Well 699-37-47A is located near the southeast corner of 200 East and about $76.2 \mathrm{~m}(250 \mathrm{ft})$ east of the south end of the FY 2008 Canton Rd seismic profile (Figure 2). The well is in an open area with primarily sand at the surface. Travel time through Hanford sediments and into the upper part of the Ringold Formation $(\mathrm{Fm})$ is provided by the check shot survey in the well. The well was originally drilled into the underlying basalt $157.6 \mathrm{~m}(517 \mathrm{ft})$ bgs but was back-filled and screened in the upper Ringold Fm. Total well depth is approximately $103 \mathrm{~m}(338 \mathrm{ft})$ bgs, and check shot surveying was completed to $101.2 \mathrm{~m}$ (332 $\mathrm{ft}$ ) in depth.

Figure 17 shows the travel time measurements and estimated velocities for Well 699-37-47A, as well as the associated gamma log and driller's description and geologic names of units encountered. Check shot survey results for Well C4562 (Northland Geophysical, 2004) were used to extend to the time-depth function to top-of-basalt. Changes in interval velocities are interpreted at $0.7 \mathrm{~m}(2.3 \mathrm{ft}), 6.9 \mathrm{~m}(22.5 \mathrm{ft})$, $25.3 \mathrm{~m}(83 \mathrm{ft}), 55.8 \mathrm{~m}(183 \mathrm{ft})$, and $91.4 \mathrm{~m}(300 \mathrm{ft})$ in depth from the travel time with depth curve. The

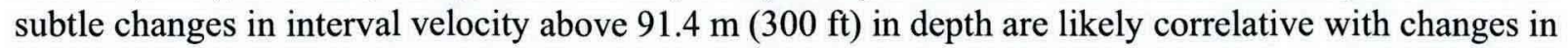
the sediment, though it is not clear whether the velocity increase $(789.1 \mathrm{~m} / \mathrm{s}$ to $982.7 \mathrm{~m} / \mathrm{s}[2,589 \mathrm{ft} / \mathrm{s}$ to $3,224 \mathrm{ft} / \mathrm{s}])$ at $55.8 \mathrm{~m}(183 \mathrm{ft})$ in depth correlates with a possible Hanford $\mathrm{H} 2 / \mathrm{H} 3$ unit boundary. Ringold Fm E-unit sediments were encountered near the bottom of the hole and correlate with a change in velocity from $982.7 \mathrm{~m} / \mathrm{s}$ to $1,189.0 \mathrm{~m} / \mathrm{s}(3,224 \mathrm{ft} / \mathrm{s}$ to $3,901 \mathrm{ft} / \mathrm{s})$. 


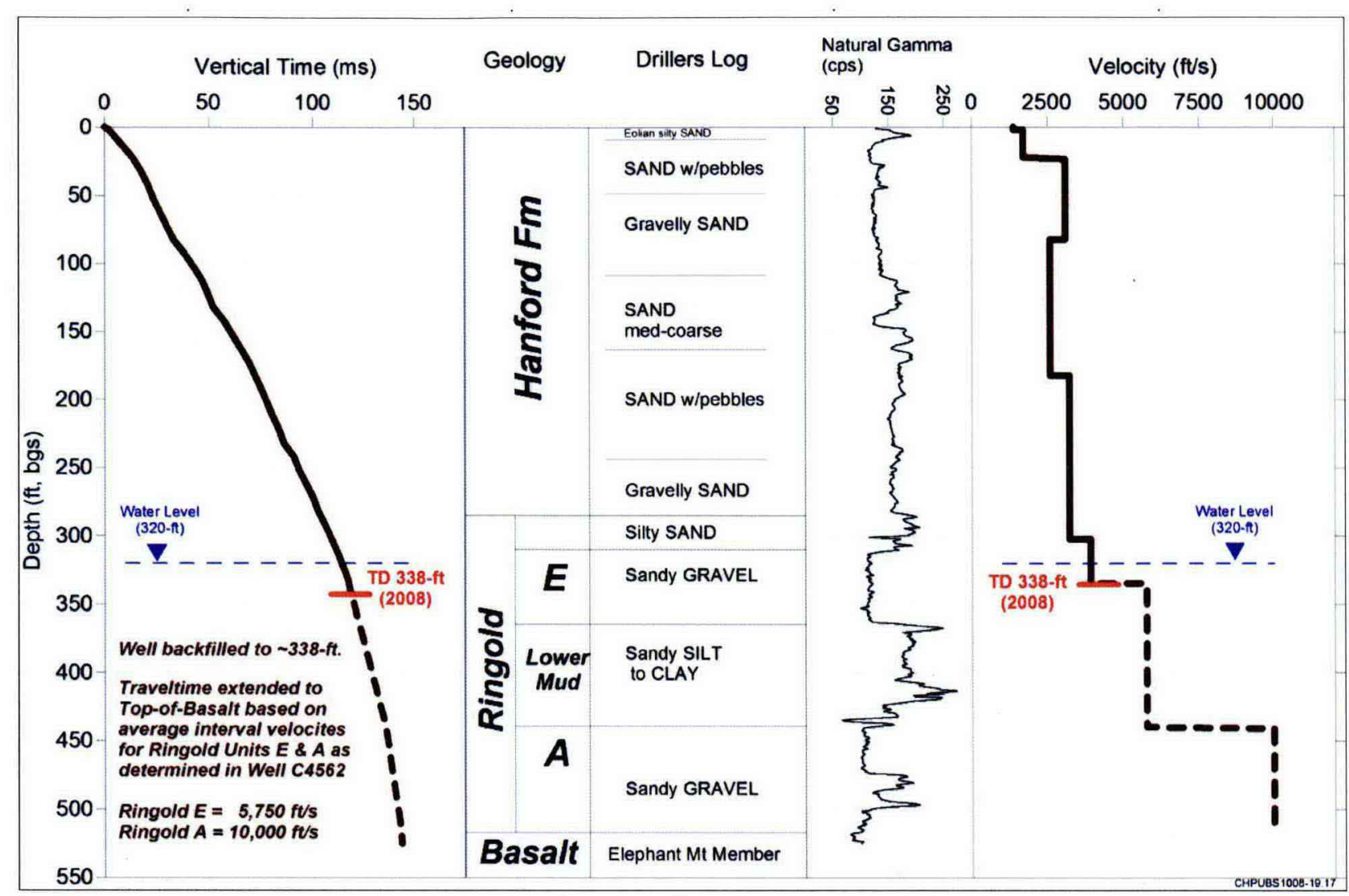

Figure 17. Check Shot Survey Results for Well 699-37-47A

\subsection{Well 699-6-2A}

Well 699-6-2A is located south of the Energy Northwest generating station, and about $914.4 \mathrm{~m}(3,000 \mathrm{ft})$ north of seismic station 440 of BWIP Profile FY79-01 (see Figure 1). The well is in an open area with primarily sand at the surface. Travel time through Hanford sediments is provided by the check shot survey in this well. The well was originally drilled into the underlying basalt (174.7 $\mathrm{m}[573 \mathrm{ft}] \mathrm{bgs})$ and Ringold Fm with casing initially set to $141.4 \mathrm{~m} 464 \mathrm{ft}$ (in upper Ringold Fm). Check shot surveying was only completed to $22.9 \mathrm{~m}$ ( $75 \mathrm{ft})$ in depth due to blockage within the well.

Results from the check shot survey in Well 699-6-2A are shown in Figure 18 along with the driller's description and geologic names of units encountered. Changes in interval velocities are interpreted at 2.3 $\mathrm{m}(14 \mathrm{ft}), 10.7 \mathrm{~m}(35 \mathrm{ft}), 18.3 \mathrm{~m}(60 \mathrm{ft}$,) and $19.8 \mathrm{~m}(65 \mathrm{ft})$ in depth based on changes in slope on the travel time with depth curve. Near-surface (upper $2.3 \mathrm{~m}[14 \mathrm{ft}])$ velocities are extremely slow $(\sim 326.1 \mathrm{~m} / \mathrm{s}$ $[\sim 1,070 \mathrm{ft} / \mathrm{s}])$ but increase to about $457.2 \mathrm{~m} / \mathrm{s}(1,500 \mathrm{ft} / \mathrm{s})$ in the $2.3 \mathrm{~m}$ to $12.2 \mathrm{~m}(14 \mathrm{ft}$ to $40 \mathrm{ft})$ depth range. These values are consistent with dry, unconsolidated sands (Press, 1966). Velocities increase to about $762 \mathrm{~m} / \mathrm{s}(2,500 \mathrm{ft} / \mathrm{s})$ below $12.2 \mathrm{~m}(40 \mathrm{ft})$ and are probably a response to the gravel zone at $12.8 \mathrm{~m}$ to $13.7 \mathrm{~m}$ (42 ft to $45 \mathrm{ft})$. 


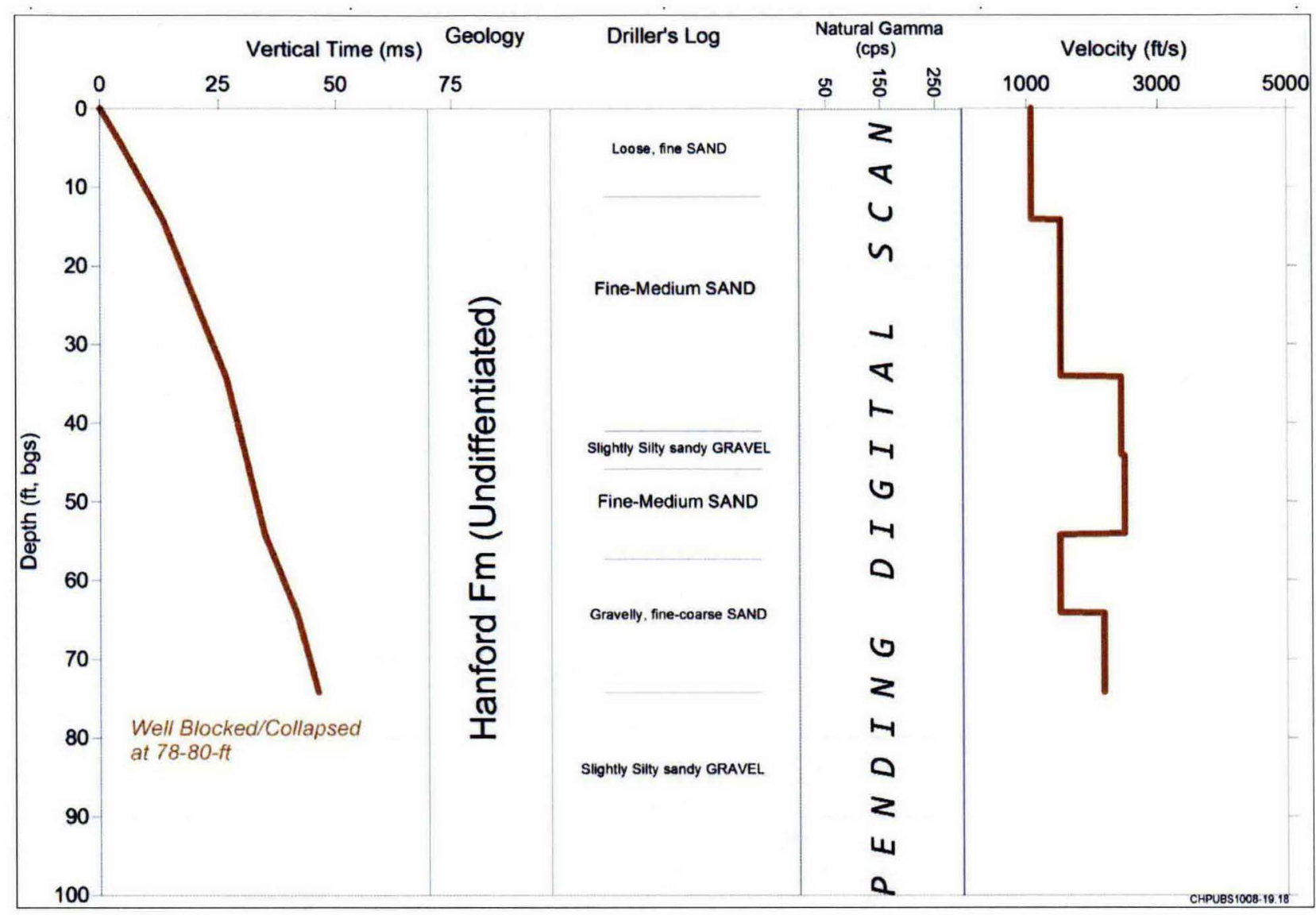

Figure 18. Check Shot Survey Results for Well 699-6-2A

\subsection{Well 699-17-47}

Well 699-17-47 is located on Army Loop Rd due south of 200 West and approximately $9.1 \mathrm{~m}$ (30 ft) south of seismic station 320 of BWIP seismic line FY80-14 (see Figure 3). Travel time through Hanford and Ringold sediments is provided by check shot measurements in the well. The well was originally

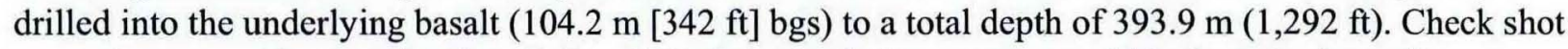

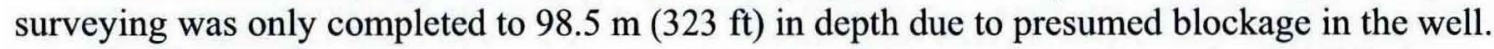

Construction summaries for the well casing indicate that it telescopes from 6 in. to 3.5-in. in diameter near $105.2 \mathrm{~m}(345 \mathrm{ft})$, below where the blockage was encountered.

Figure 19 shows the travel time measurements and estimated velocities for Well 699-17-47, as well as the associated gamma log, driller's description and geologic names of units encountered. Changes in seismic

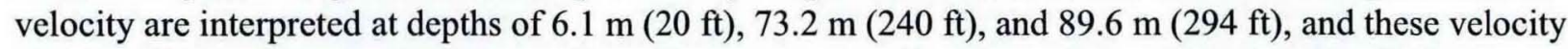
changes likely correspond to changes in sediment type (e.g. from gravels to clays). The Hanford-Ringold interface is not documented, and tube-wave interference between $15.2 \mathrm{~m}(50 \mathrm{ft})$ and $54.9 \mathrm{~m}(180 \mathrm{ft})$ in depth (see Figure A7) precluded using the check shot data to help identify this interface. The change in velocity from $701 \mathrm{~m} / \mathrm{s}$ to $1,097.3 \mathrm{~m} / \mathrm{s}(2,300 \mathrm{ft} / \mathrm{s}$ to $3,600 \mathrm{ft} / \mathrm{s})$ corresponds with the change from sands (3 $\mathrm{m}$ to $39.6 \mathrm{~m}[10 \mathrm{ft}$ to $130 \mathrm{ft}])$ to cemented gravels $(48.8 \mathrm{~m}$ to $70.1 \mathrm{~m}[160 \mathrm{ft}$ to $230 \mathrm{ft}])$. 


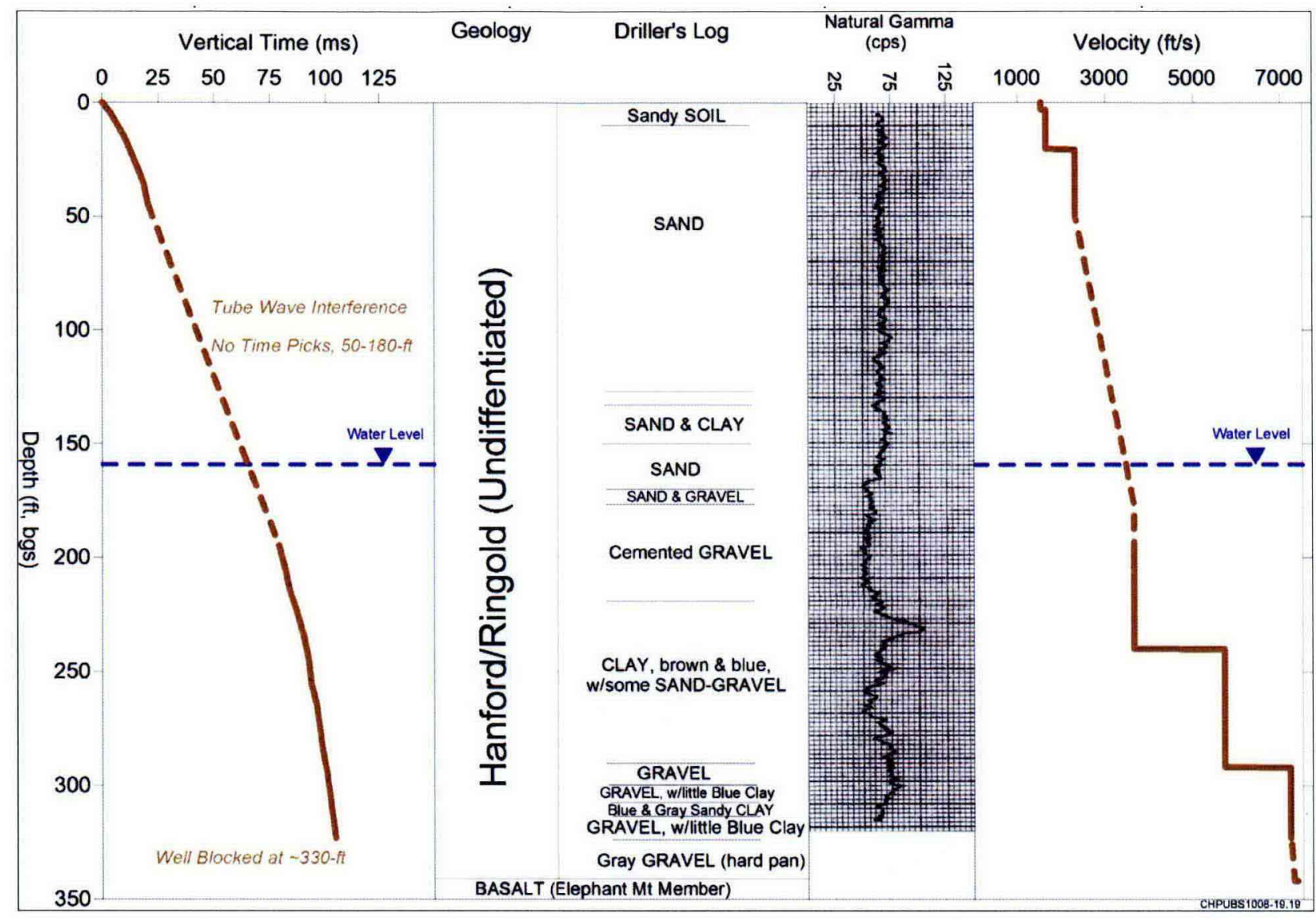

Figure 19. Check Shot Survey Results for Well 699-17-47

\subsection{Well 699-26-15C}

Well $699-26-15 \mathrm{C}$ is located about $2.8 \mathrm{~km}(1.75 \mathrm{mi})$ north of the Wye Barricade and approximately $12.2 \mathrm{~m}$ (40 ft) east of Route $2 \mathrm{~S}$, and is used to correlate subsurface geology with BWIP profile FY79-02 near seismic station 720 (Figure 3). Check shot surveys provide travel time measurements through Hanford

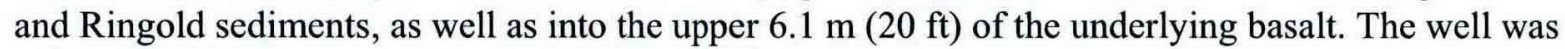
originally drilled to a total depth of $192.0 \mathrm{~m}(630 \mathrm{ft})$ and encountered top-of-basalt at $184.4 \mathrm{~m} \mathrm{bgs}(605 \mathrm{ft}$ bgs). Check shot surveying was completed to $190.5 \mathrm{~m}(625 \mathrm{ft})$ in depth.

Check shot results for Well 699-26-15C are shown in Figure 20 along with the associated gamma log, driller's description and geologic names of units encountered. Seismic velocities rapidly increase in the upper $7.6 \mathrm{~m}(25 \mathrm{ft})$ from $\sim 396.2 \mathrm{~m} / \mathrm{s}(\sim 1,300 \mathrm{ft} / \mathrm{s})$ to over $1,828.8 \mathrm{~m} / \mathrm{s}(6,000 \mathrm{ft} / \mathrm{s})$, and remain above $1,524 \mathrm{~m} / \mathrm{s}(5,000 \mathrm{ft} / \mathrm{s})$ to the base of hole. The velocity increase near $7.62 \mathrm{~m}(25 \mathrm{ft})$ in depth is consistent with a change from unsaturated to saturated conditions. Decrease in velocity between $45.7 \mathrm{~m}(150 \mathrm{ft})$ and $61 \mathrm{~m}(200 \mathrm{ft})$ correlates with clay and silt zones indicated on the driller's description. Another decrease in

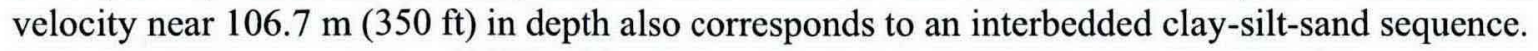
Velocity of the upper $6.1 \mathrm{~m}(20 \mathrm{ft})$ of basalt is estimated at $\sim 3,657.6 \mathrm{~m} / \mathrm{s}(\sim 12,000 \mathrm{ft} / \mathrm{s})$. 


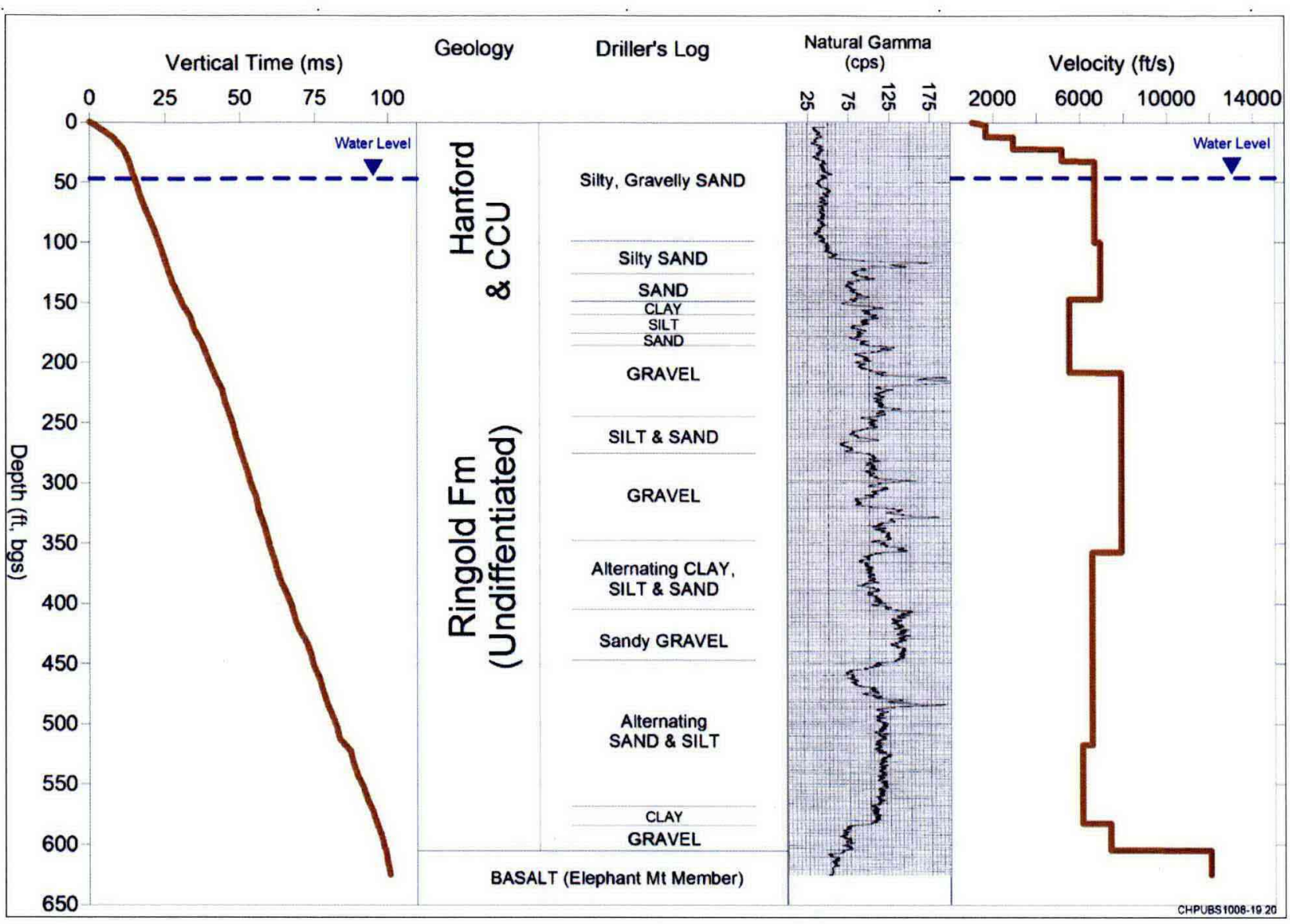

Figure 20. Check Shot Survey Results for Well 699-26-15C

\subsection{Well 699-49-57B}

Well 699-49-57B is located northwest of the 200 East Area and southeast of the intersection of Routes $11 \mathrm{~A}$ and 4 (about $365.8 \mathrm{~m}$ (1200 ft) east of Route $4 \mathrm{~S}$ and $304.8 \mathrm{~m}(1000 \mathrm{ft})$ south of $11 \mathrm{~A})$. Information from this well supports interpretation of BWIP profiles FY79-03 and FY80-12, and Landstreamer profile FY09-L-2A (SGW-43746) (see Figure 4). Check shot surveys provide travel time measurements through Hanford, the Elephant Mountain (Mt) basalt, as well as the upper $4.6 \mathrm{~m}$ (15 ft) of the Rattlesnake Ridge interbed. The well was originally drilled to a total depth of approximately $70.1 \mathrm{~m}(230 \mathrm{ft})$ and encountered top-of-basalt at $49.5 \mathrm{~m}(162.5 \mathrm{ft})$. Check shot surveying was completed to the bottom of the well $(70.1 \mathrm{~m}$ $[230 \mathrm{ft}])$.

Check shot results for Well 699-49-57B are shown in Figure 21 along with the driller's description and geologic names of units encountered. Seismic velocities increase in the upper $4.6 \mathrm{~m}$ (15 ft) from $\sim 426.7$ $\mathrm{m} / \mathrm{s}(\sim 1,400 \mathrm{ft} / \mathrm{s})$ to about $823 \mathrm{~m} / \mathrm{s}(2,700 \mathrm{ft} / \mathrm{s})$ to $883.9 \mathrm{~m} / \mathrm{s}(2,900 \mathrm{ft} / \mathrm{s})$, and remain in the $609.6 \mathrm{~m} / \mathrm{s}$ $(2,000 \mathrm{ft} / \mathrm{s})$ to $823 \mathrm{~m} / \mathrm{s}(2,700 \mathrm{ft} / \mathrm{s})$ range until about $39.6 \mathrm{~m}(130 \mathrm{ft})$ in depth. This range in velocity is consistent with dry, unconsolidated sands. A velocity increase from $\sim 810.8 \mathrm{~m} / \mathrm{s}(\sim 2,660 \mathrm{ft} / \mathrm{s})$ to $1,051.6$ $\mathrm{m} / \mathrm{s}(3,450 \mathrm{ft} / \mathrm{s})$ occurs between $39.6 \mathrm{~m}(130 \mathrm{ft})$ to $42.7 \mathrm{~m}(140 \mathrm{ft})$ and likely corresponds to the gravel units below $38.1 \mathrm{~m}(125 \mathrm{ft})$. Saturated gravels likely correspond with the increase in velocity to above $5,000 \mathrm{ft} / \mathrm{s}$ in the $3 \mathrm{~m}(10 \mathrm{ft})$ thick zone immediately above the basalt. 


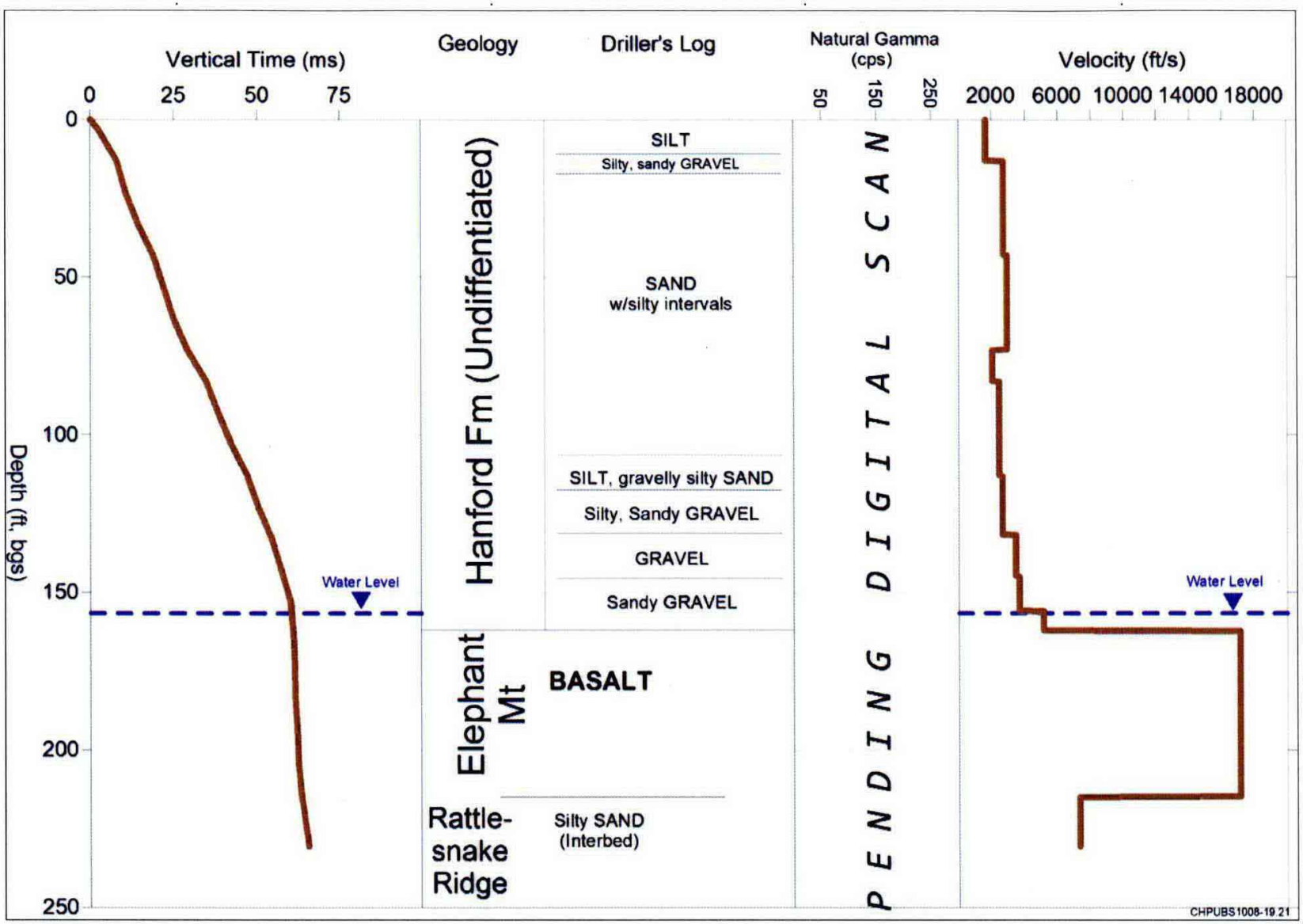

Figure 21. Check Shot Survey Results for Well 699-49-57B

Check shot measurements through the $\sim 15.2 \mathrm{~m}$ ( $\sim 50 \mathrm{ft})$ thick basalt zone estimate a seismic velocity of about $5,181.6 \mathrm{~m} / \mathrm{s}(17,000 \mathrm{ft} / \mathrm{s})$ for the basalt. The upper $4.6 \mathrm{~m}(15 \mathrm{ft})$ of the interbed is estimated at approximately $2,225.0 \mathrm{~m} / \mathrm{s}(7,300 \mathrm{ft} / \mathrm{s})$ in seismic velocity.

\subsection{Well 699-50-30}

Well $699-50-30$ is north of Route 11A about $4.8 \mathrm{~km} \mathrm{(3} \mathrm{mi)} \mathrm{east} \mathrm{of} \mathrm{the} 200$ East Area and check shot surveys in this well provide support for interpreting BWIP profile FY79-03 (see Figure 1 and Figure 3). Check shot surveys provide travel time measurements through Hanford and Ringold units that occur on the down thrown side of the May Junction Fault. The well was originally drilled to a total depth of approximately $115.8 \mathrm{~m}(380 \mathrm{ft})$, and was back-filled and plugged at $50.3 \mathrm{~m}(165 \mathrm{ft})$. Check shot surveys were conducted to $\sim 43.9 \mathrm{~m}(\sim 144 \mathrm{ft})$ in depth.

Results for Well 699-50-30 are shown in Figure 22 along with the associated gamma log, driller's description and geologic names of units encountered. Seismic velocities increase in the upper $4.3 \mathrm{~m}$ (14 $\mathrm{ft})$ from $\sim 609.6 \mathrm{~m} / \mathrm{s}(\sim 2,000 \mathrm{ft} / \mathrm{s})$ to about $731.5 \mathrm{~m} / \mathrm{s}(2,400 \mathrm{ft} / \mathrm{s})$ to $853.4(2,800 \mathrm{ft} / \mathrm{s})$, and remain in this

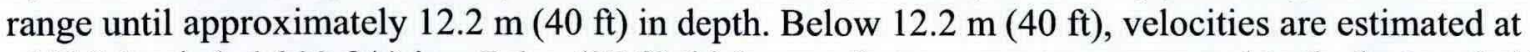
$\sim 1310.6 \mathrm{~m} / \mathrm{s}(\sim 4,300 \mathrm{ft} / \mathrm{s})$ in a $7.6 \mathrm{~m}(25 \mathrm{ft})$ thick zone that appears to correspond to the bottom half of the clay zone indicated by the driller's log. Below $19.8 \mathrm{~m}(65 \mathrm{ft})$ in depth, changes in interval velocity appear

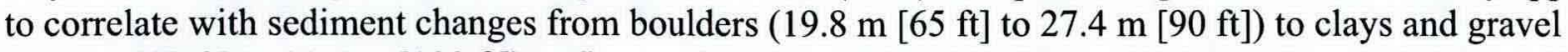
$(27.4 \mathrm{~m}[90 \mathrm{ft}]$ to $30.5 \mathrm{~m}[100 \mathrm{ft}])$ to fine sand $(34.4 \mathrm{~m}$ [113 ft] to $42.7 \mathrm{~m}$ [140 ft]). Current interpretations place the top of Ringold near 23.4 ( $80 \mathrm{ft}$ ) bgs. Seismic velocities for the sandy clay zone below the water table are estimated at $\sim 1,828.8 \mathrm{~m} / \mathrm{s}(\sim 6,000 \mathrm{ft} / \mathrm{s})$. 


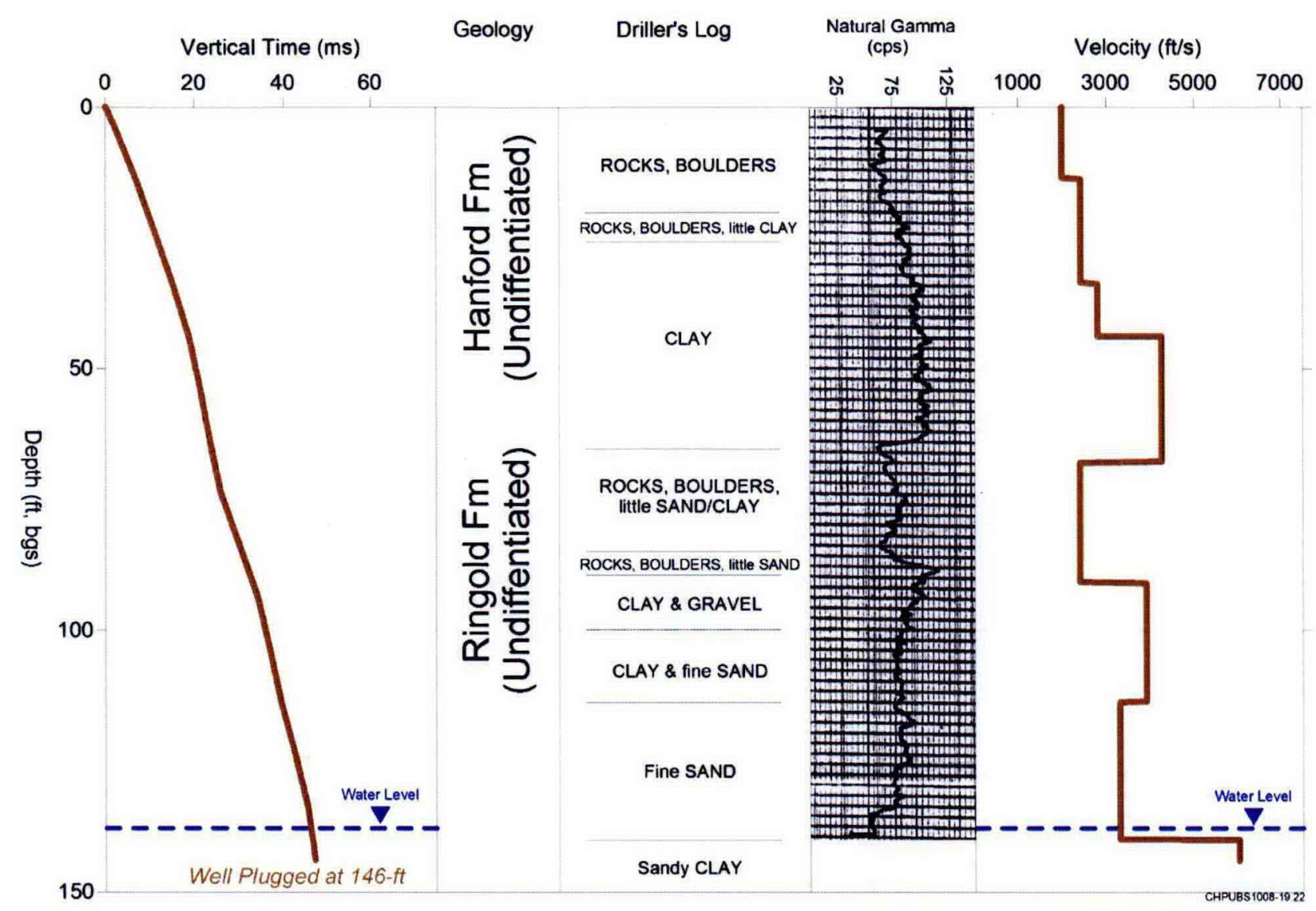

Figure 22. Check Shot Survey Results for Well 699-50-30

\subsection{Well 699-54-47}

Well 699-54-47 is located in the Gable Gap region, about $1.61 \mathrm{~km}(1 \mathrm{mi})$ north of the intersection between Route 11A and Route 4N (see Figure 1 and Figure 4). Check shot surveys in this well supports interpretation of Landstreamer seismic profile FY09-L-4B. Travel time measurements were conducted through sands and gravels of the Hanford Fm and include the upper $18.3 \mathrm{~m}(60 \mathrm{ft})$ of the underlying Elephant Mt basalt. The well was originally drilled to a total depth of approximately $97.5(320 \mathrm{ft})$ and has been backfilled and plugged near $80.8 \mathrm{~m}$ (265 ft) in depth. Check shot surveys were only conducted to $\sim 72.5 \mathrm{~m}(\sim 238 \mathrm{ft})$ in depth.

Results for Well 699-54-57 are shown in Figure 23 along with the associated gamma log and driller's description and geologic names of units encountered. Seismic velocities between $4 \mathrm{~m}(13 \mathrm{ft})$ and $51.8 \mathrm{~m}$ $(170 \mathrm{ft})$ in depth remain within a fairly narrow range of $1,005.8 \mathrm{~m} / \mathrm{s}(3,300 \mathrm{ft} / \mathrm{s})$ to $1,066.8 \mathrm{~m} / \mathrm{s}(3,500$ $\mathrm{ft} / \mathrm{s}$ ), consistent with dry gravels (Press, 1966). Measurements within the basalt indicate a seismic velocity of approximately $4,572 \mathrm{~m} / \mathrm{s}(15,000 \mathrm{ft} / \mathrm{s})$. 


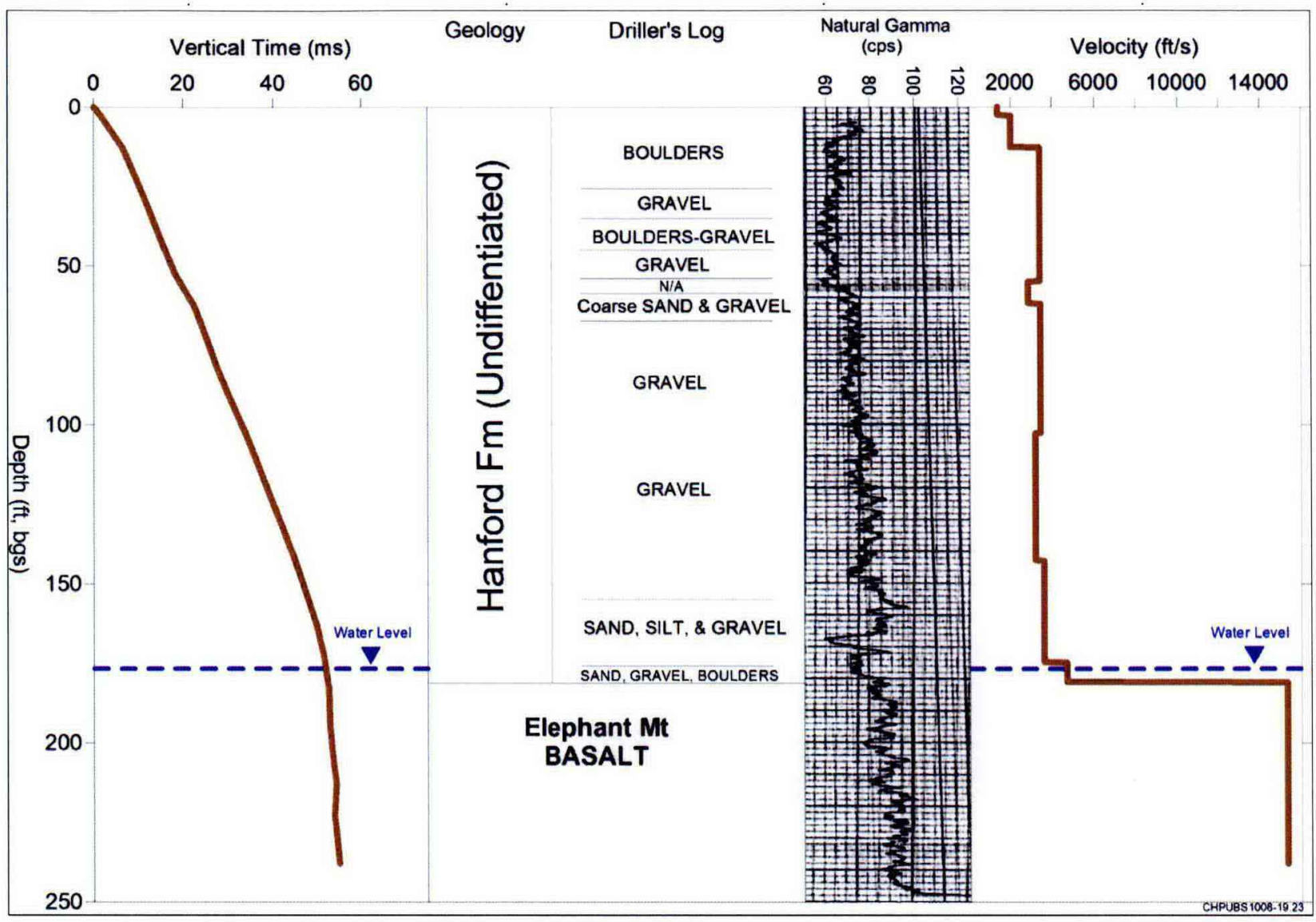

Figure 23. Check Shot Survey Results for Well 699-54-57

\subsection{Well 699-60-59}

Well 699-60-59 is located in the Gable Gap region about $3.2 \mathrm{~km}(2 \mathrm{mi})$ north of the intersection of Route $11 \mathrm{~A}$ and Route $4 \mathrm{~N}$ (see Figure 1 and Figure 4). Information from this well supports interpretation of Landstreamer Profile FY09-L-2C and BWIP Profile FY79-04. Check shot surveys were conducted through gravels of the Hanford Fm, the Asotin and Umatilla basalt units, and the upper Mabton Interbed. The well was originally drilled to a total depth of approximately $475.8 \mathrm{~m}(1,561 \mathrm{ft})$ and check shot surveys were conducted to $\sim 157 \mathrm{~m}(\sim 515 \mathrm{ft})$ in depth.

A summary of results for Well 699-60-59 is shown in Figure 24 along with the driller's description and geologic names of units encountered. Seismic velocities increase with depth, starting at approximately $487.7 \mathrm{~m} / \mathrm{s}(1,600 \mathrm{ft} / \mathrm{s})$ near the surface to about $914.4 \mathrm{~m} / \mathrm{s}(3,000 \mathrm{ft} / \mathrm{s})$ to approximately $15.2 \mathrm{~m}(50 \mathrm{ft})$ in depth. Below $15.2 \mathrm{~m}(50 \mathrm{ft})$, velocity of the gravel units is about $1,249.7 \mathrm{~m} / \mathrm{s}(4,100 \mathrm{ft} / \mathrm{s})($ unsaturated) and $1,859.3 \mathrm{~m} / \mathrm{s}(6,100 \mathrm{ft} / \mathrm{s})$ (saturated). 


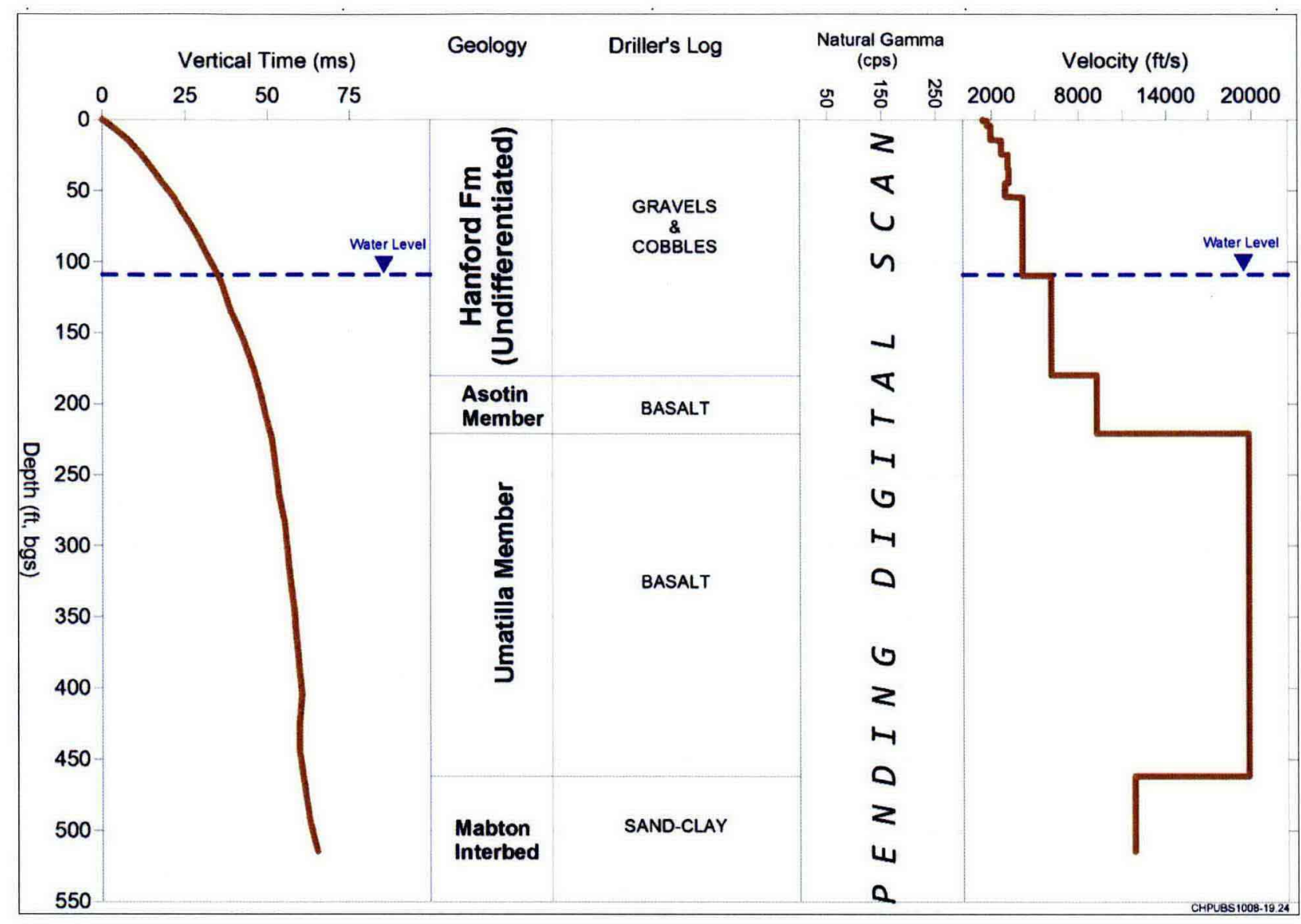

Figure 24. Check Shot Survey Results for Well 699-60-59

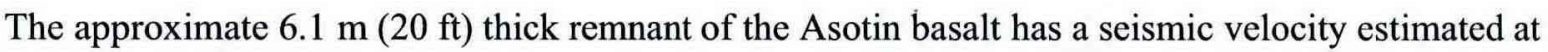
$2,804.1 \mathrm{~m} / \mathrm{s}(9200 \mathrm{ft} / \mathrm{s})$, which is lower than basalt velocities obtained in wells $699-49-57 \mathrm{~B}(\sim 5,181.6 \mathrm{~m} / \mathrm{s}$ $[\sim 17,000 \mathrm{ft} / \mathrm{s}]), 699-54-57(\sim 4,572 \mathrm{~m} / \mathrm{s}[\sim 15,000 \mathrm{ft} / \mathrm{s}])$, but consistent with estimates for wells 699-50-59 $(\sim 3,139.4 \mathrm{~m} / \mathrm{s}[\sim 10,300 \mathrm{ft} / \mathrm{s}]), 699-52-55 \mathrm{~B}(\sim 2,682.2 \mathrm{~m} / \mathrm{s}[\sim 8,880 \mathrm{ft} / \mathrm{s}])$ and $699-63-58(\sim 2,651,8 \mathrm{~m} / \mathrm{s}$ $[\sim 8,700 \mathrm{ft} / \mathrm{s}])$. Seismic velocity of the Umatilla basalt is estimated at approximately $6,096 \mathrm{~m} / \mathrm{s}(20,000$ $\mathrm{ft} / \mathrm{s}$ ) which indicates an extremely competent geologic unit. The underlying Mabton Interbed is interpreted to have a seismic velocity of about $3,596.6 \mathrm{~m} / \mathrm{s}(11,800 \mathrm{ft} / \mathrm{s})$.

\subsection{Well 199-B2-14}

Well 199-B2-14 is located in the northern part of the $100 \mathrm{BC}$ Area, and is used to provide interpretation support for BWIP Profile FY79-05 (see Figure 1 and Figure 5). Travel time measurements were only competed through gravels and sands of the Hanford Fm to a depth of $21.3 \mathrm{~m} \mathrm{(70} \mathrm{ft).} \mathrm{The} \mathrm{well} \mathrm{was}$ originally drilled to a depth of $48.2 \mathrm{~m}(158 \mathrm{ft})$ and encountered a mud unit near $43.9 \mathrm{~m}(144 \mathrm{ft})$ in depth. The well was subsequently back filled and plugged at $\sim 22.9 \mathrm{~m}(\sim 75 \mathrm{ft})$ in depth.

Results for Well 199-B2-14 are shown in Figure 25 along with the associated gamma log, driller's description and geologic names of units encountered. Seismic velocities increase with depth, starting at approximately $457.2 \mathrm{~m} / \mathrm{s}(1,500 \mathrm{ft} / \mathrm{s})$ near the surface to about $914.4 \mathrm{~m} / \mathrm{s}(3,000 \mathrm{ft} / \mathrm{s})$ to approximately

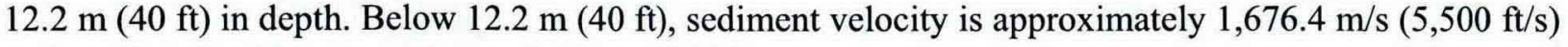
and consistent with saturated gravels (Press, 1966). 


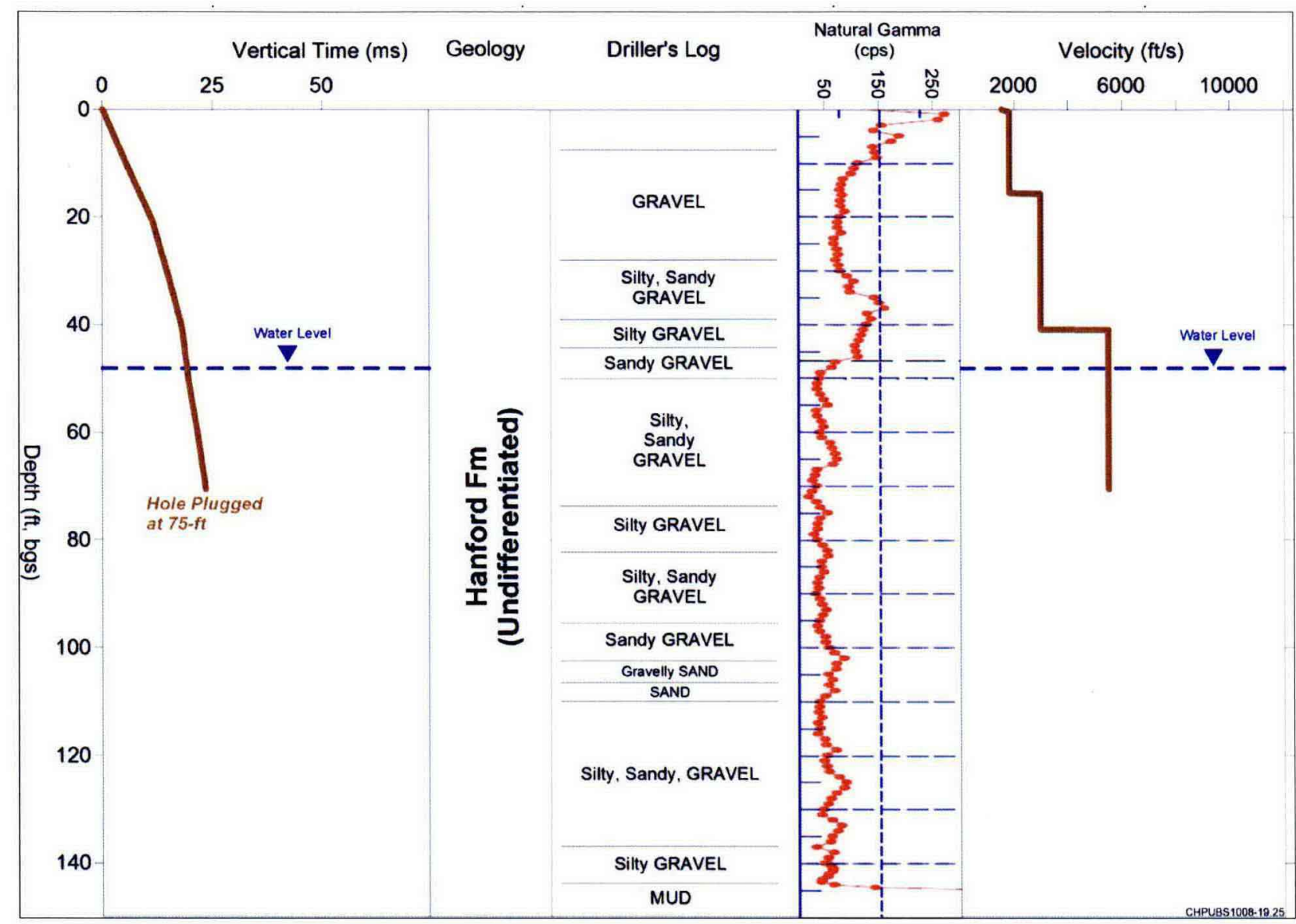

Figure 25. Check Shot Survey Results for Well 199-B2-14

\subsection{Well 199-B9-2}

Well 199-B9-2 is located in the southeastern part of the $100 \mathrm{BC}$ Area, and provides interpretation support for BWIP Profile FY-9-05 (see Figure 1 and Figure 5). Travel time measurements were completed through Hanford gravels a depth of $\sim 33.5 \mathrm{~m}(\sim 110 \mathrm{ft})$. The well was originally drilled to a depth of $36 \mathrm{~m}$ $(118 \mathrm{ft})$, and water occurs at approximately $29.3 \mathrm{~m}(96 \mathrm{ft})$ in depth.

Check shot results for Well 199-B9-2 are shown in Figure 26 along with the driller's description, natural gamma log and geologic names of units encountered. Seismic velocities of the unsaturated gravel units average around $670.6 \mathrm{~m} / \mathrm{s}(2,200 \mathrm{ft} / \mathrm{s})(0.6 \mathrm{~m} \mathrm{[2} \mathrm{ft}]$ to $29 \mathrm{~m}$ [95 ft]) and show a total range in velocity from $563.9 \mathrm{~m} / \mathrm{s}(1,850 \mathrm{ft} / \mathrm{s})$ to $823 \mathrm{~m} / \mathrm{s}(2,700 \mathrm{ft} / \mathrm{s})$. The increase in velocity below the water table $(1371.6 \mathrm{~m} / \mathrm{s}$ $[4,500 \mathrm{ft} / \mathrm{s}]$ ) is consistent with saturated sediment values (Press, 1966).

\subsection{Well 299-E33-340}

Well 299-E33-340 is located north of the intersection of Baltimore Rd and $12^{\text {th }} \mathrm{St}$ in the 200 East Area (see Figure 1 and Figure 2). Check shot surveys in this well supports interpretation of the Baltimore Rd and $12^{\text {th }} \mathrm{St}$ seismic profiles acquired in FY2008. Travel time measurements were conducted through sands and gravels of the Hanford Fm, the Elephant Mt basalt, and the upper $4.6 \mathrm{~m}$ (15 ft) of the Rattlesnake Interbed. The well was originally drilled to a total depth of approximately $109.4 \mathrm{~m} \mathrm{(359 \textrm {ft } )}$

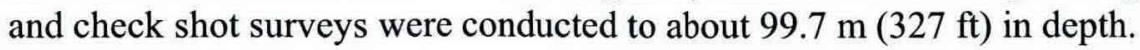




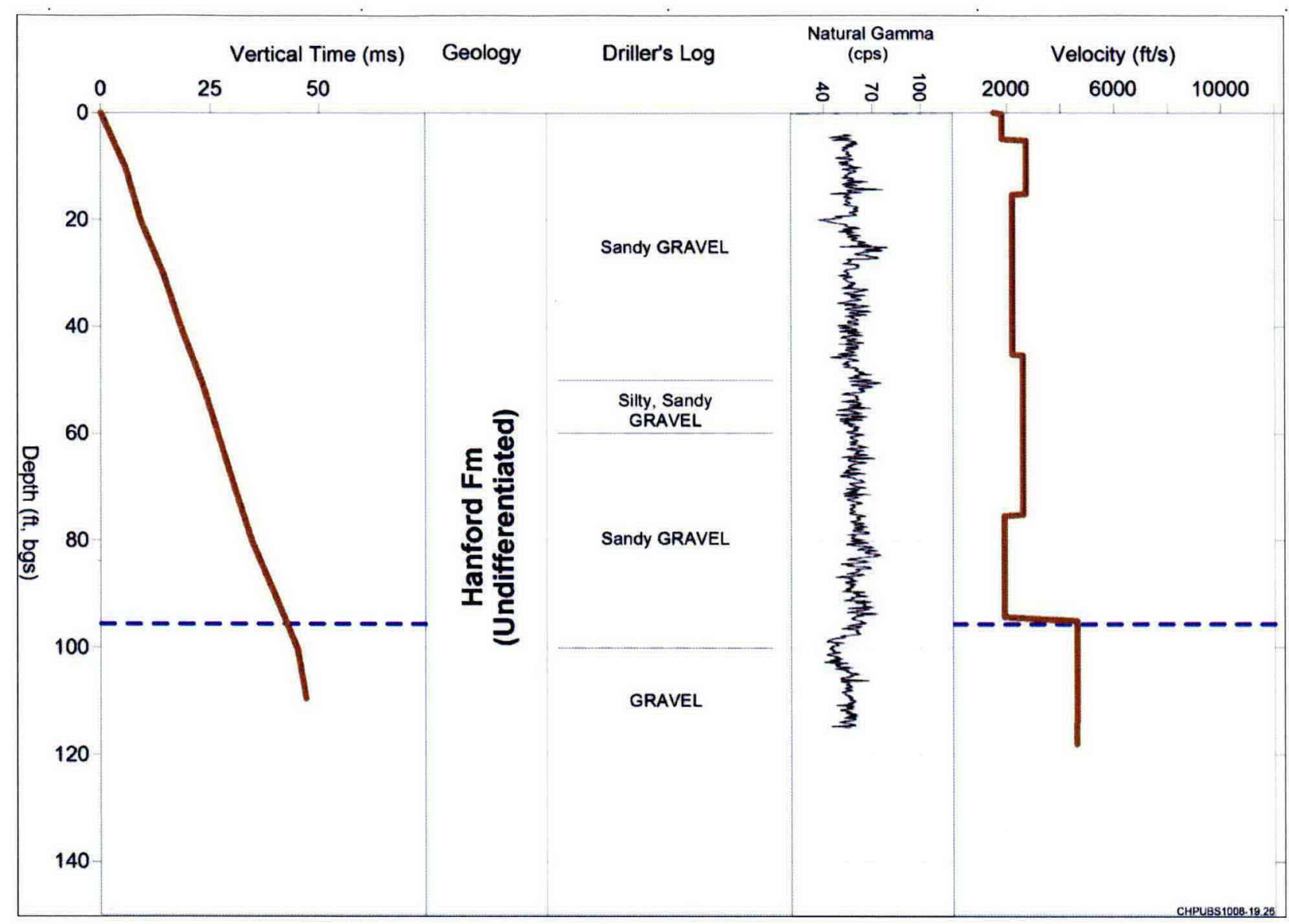

Figure 26. Check Shot Survey Results for Well 199-B9-2

Figure 27 shows the results for the check shot survey in 299-E33-340, along with the driller's description and geologic names of units encountered. Seismic velocities average about $792.5 \mathrm{~m} / \mathrm{s}(2,600 \mathrm{ft} / \mathrm{s})$ in the 3 $\mathrm{m}(10 \mathrm{ft})$ to $45.7 \mathrm{~m}(150 \mathrm{ft})$ depth range, and correlate with predominantly sand intervals with increases in silt and/or gravel content corresponding to zones with slightly increased velocity. Gravels and sandy gravels below $45.7 \mathrm{~m}(150 \mathrm{ft})$ in depth have a correspondingly increased seismic velocity of about 1,003,8

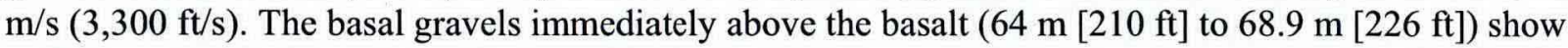
an increased velocity of $2,164.1 \mathrm{~m} / \mathrm{s}(7,100 \mathrm{ft} / \mathrm{s})$, which is most likely due to increased saturation levels associated with the water head. Velocity for the Elephant Mt basalt is approximately $3,749 \mathrm{~m} / \mathrm{s}(12,300$ $\mathrm{ft} / \mathrm{s}$ ), and the few check shot points in the underlying interbed indicate a seismic velocity of $\sim 1,676.4 \mathrm{~m} / \mathrm{s}$ $(\sim 5,500 \mathrm{ft} / \mathrm{s})$.

\subsection{Well 299-E34-5}

Well 299-E34-5 is located in the northeastern part of the 200 East along $12^{\text {th }} \mathrm{St}$ (see Figure 1 and Figure 2), with check shot surveys in this well used to support interpretation of FY 2008 seismic profile collected along $12^{\text {th }}$ Street. Check shot measurements were conducted through gravels and sands of the Hanford Fm. Well 299-E34-5 was originally completed to $58.1 \mathrm{~m}(190.5 \mathrm{ft})$ in depth, and encountered basalt at $57.9 \mathrm{~m}(190 \mathrm{ft})$. Total survey depth is approximately $55.2 \mathrm{~m}(181 \mathrm{ft})$ where the downhole geophone bottomed out in muddy material. 


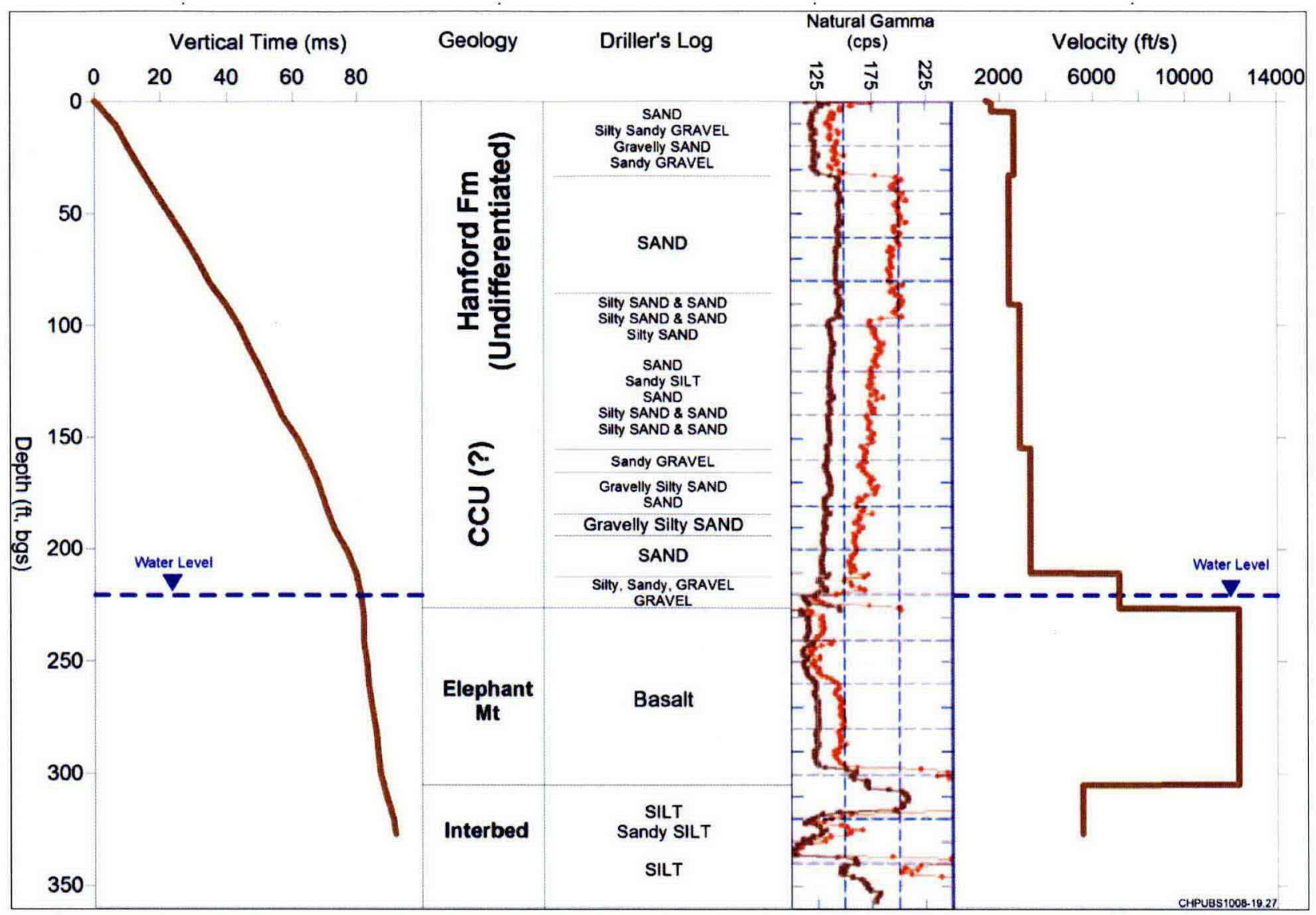

Figure 27. Check Shot Survey Results for Well 299-E33-340

Check shot results are shown in Figure 28 along with the natural gamma log, driller's description and geologic names of units encountered. Below $1.5 \mathrm{~m}(5 \mathrm{ft})$ in depth, seismic velocities range from $691.9 \mathrm{~m} / \mathrm{s}$ $(2,270 \mathrm{ft} / \mathrm{s})$ to $1,084.5 \mathrm{~m} / \mathrm{s}(3,558 \mathrm{ft} / \mathrm{s})$, with changes in velocity possibly correlative with sediment type

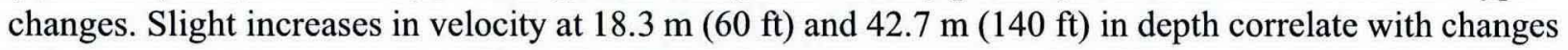
in increases in the gamma-log. The entire check shot survey was completed in unsaturated sediments, and observed velocities compatible with published results.

\subsection{Well 699-28-30}

Well 699-28-30 is located in the 200-PO-1 OU along Route 4S, approximately $6.4 \mathrm{~km} \mathrm{(4} \mathrm{mi)} \mathrm{southeast} \mathrm{of}$ 200 East and provides time-depth information for BWIP profiles FY80-10 and FY80-11 (see Figure 1 and Figure 3). Check shot surveys were conducted through sands and gravels of the Hanford Fm and possibly the pre-Missoula Cold Creek Units (CCUs). Well 699-28-30 was originally completed to a depth of 291.7 $\mathrm{m}(957 \mathrm{ft})$ and encountered basalt unit tops at $217.9 \mathrm{~m}(715 \mathrm{ft})$ and $275.8(905 \mathrm{ft})$, but is apparently plugged at $53.9 \mathrm{~m}(177 \mathrm{ft})$.

Figure 29 shows the check shot results for Well 699-28-30 along with the driller's description and geologic names of units encountered. Seismic velocity show a general increase with depth, starting with value $335.3 \mathrm{~m} / \mathrm{s}(1,100 \mathrm{ft} / \mathrm{s})$ near the ground surface and increasing to $1,036.3 \mathrm{~m} / \mathrm{s}(3,400 \mathrm{ft} / \mathrm{s})$ in the 18.3 $\mathrm{m}(60 \mathrm{ft}) 24.4(80 \mathrm{ft})$ depth range (corresponds to a change from sands to gravels). Velocities decrease to about $640.1 \mathrm{~m} / \mathrm{s}(2,100 \mathrm{ft} / \mathrm{s})$ for a silty gravel zone. Below the water table, saturated gravels have a seismic velocity of about $1,950.7 \mathrm{~m} / \mathrm{s}(6,400 \mathrm{ft} / \mathrm{s})$ which is consistent with published values for saturated gravels and sands. 


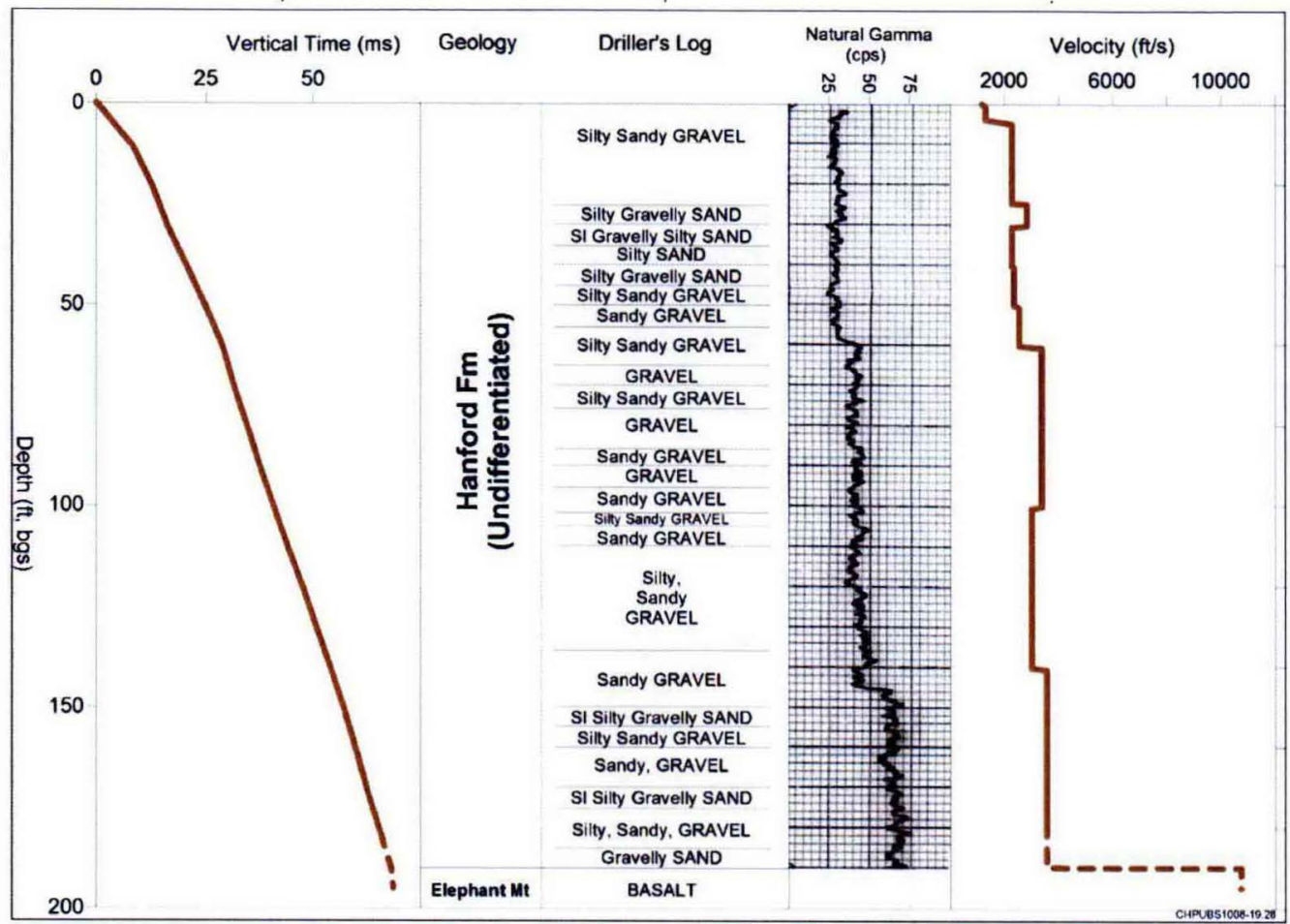

Figure 28. Check Shot Survey Results for Well 299-E34-5

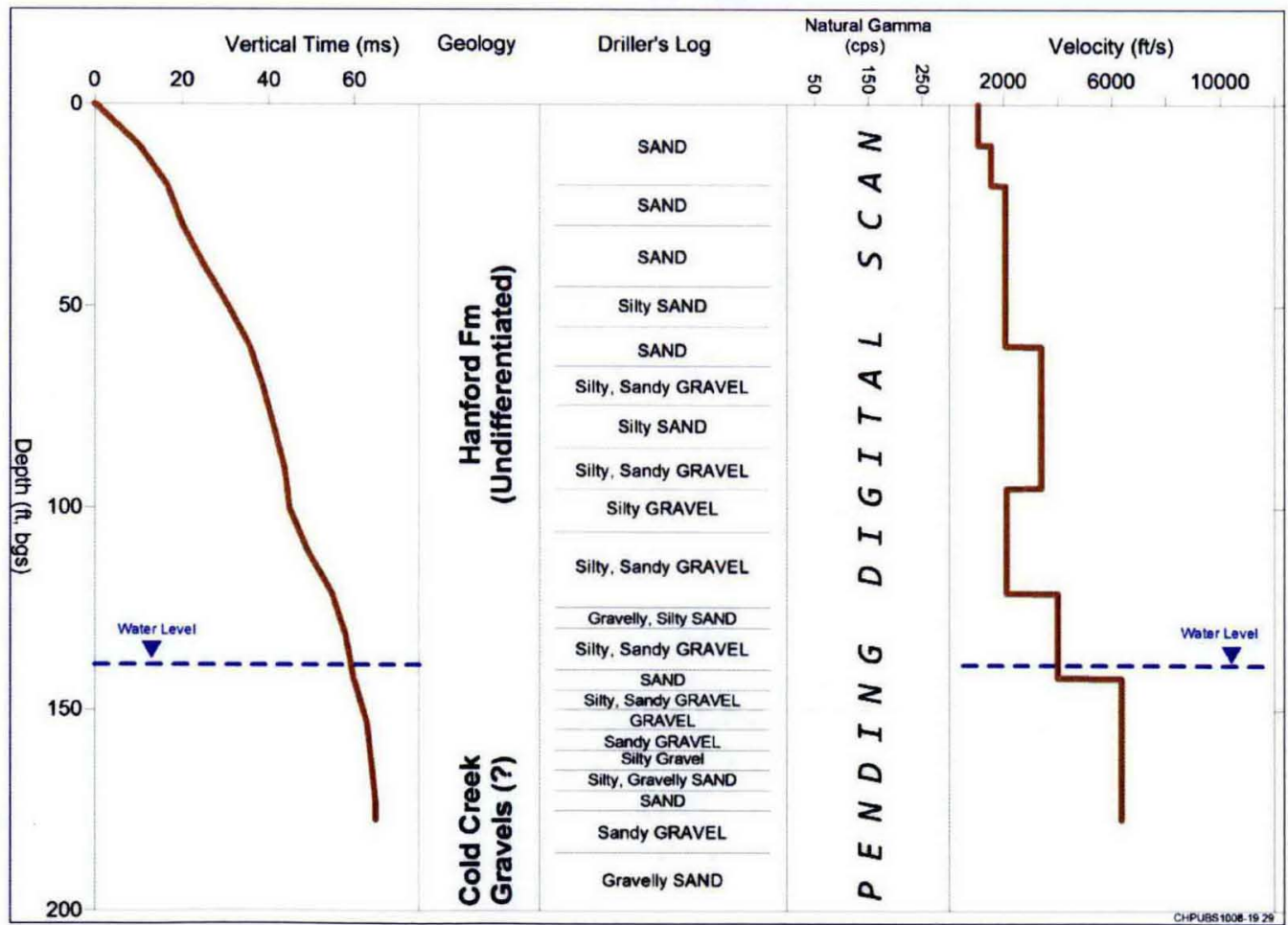

Figure 29. Check Shot Survey Results for Well 699-28-30 


\subsection{Well 699-31-17}

Well 699-31-17 is located in the 200-PO-1 OU about $4.8 \mathrm{~km} \mathrm{(3} \mathrm{mi)} \mathrm{north} \mathrm{of} \mathrm{the} \mathrm{Wye} \mathrm{Barricade} \mathrm{along}$ Route 2S (see Figure 1 and Figure 3). Surveys in this well support interpretation of BWIP Profile FY7902, and provide travel time information to the top-of-basalt through Hanford, Cold Creek, and Ringold Units. The well was originally drilled to a total depth of approximately $195.1 \mathrm{~m}(640 \mathrm{ft})$, back filled to $192.9 \mathrm{~m}(633 \mathrm{ft})$, and check shot surveys were conducted to $182.9 \mathrm{~m}(600 \mathrm{ft})$ in depth.

Results for Well 699-31-17 are shown in Figure 30 along with the natural gamma log, driller's description and geologic names of units encountered. Seismic velocities increase quickly with depth in the upper 12.2 $\mathrm{m}(40 \mathrm{ft})$, starting at approximately $457.2 \mathrm{~m} / \mathrm{s}(1,500 \mathrm{ft} / \mathrm{s})$ near the ground surface and increasing to about $1,188.7 \mathrm{~m} / \mathrm{s}(3,900 \mathrm{ft} / \mathrm{s})$ at the water table (same depth as the Hanford - CCU contact identified on the driller's $\log )$. Seismic velocity increase to about $1828.8 \mathrm{~m}(6,000 \mathrm{ft} / \mathrm{s})$ across the CCU-Ringold contact. Within the Ringold, velocities range from $1935.5 \mathrm{~m} / \mathrm{s}(6,350 \mathrm{ft} / \mathrm{s})$ to $2,712.7 \mathrm{~m} / \mathrm{s}(8,900 \mathrm{ft} / \mathrm{s})$. The zone of

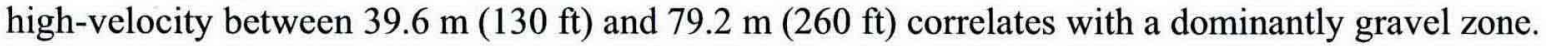
Seismic velocity within the upper $15.2 \mathrm{~m}(50 \mathrm{ft})$ of basalt is estimated at approximately $3,352.8 \mathrm{~m} / \mathrm{s}$ $(11,000 \mathrm{ft} / \mathrm{s})$.

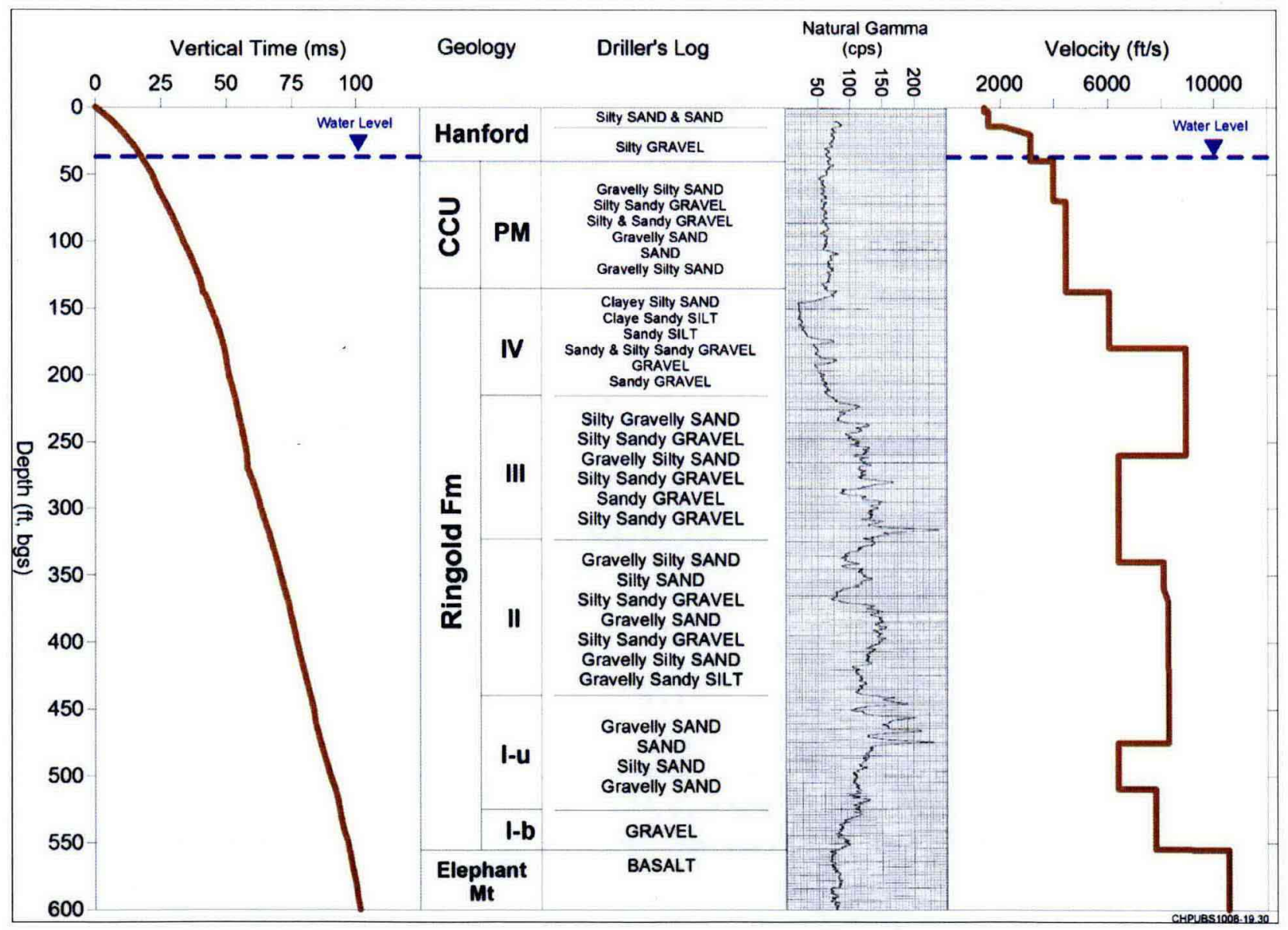

Figure 30. Check Shot Survey Results for Well 699-31-17 


\subsection{Well 699-36-27}

Well 699-36-27 is located in the 200-PO-1 OU about $6.4 \mathrm{~km} \mathrm{(4} \mathrm{mi)} \mathrm{east-southeast} \mathrm{of} 200$ East (see Figure 1 and Figure 3). Check shot surveys in this well support interpretation of BWIP Profile FY80-11, and provide time-depth information through Hanford units and into the upper part of the Ringold Fm. The well is located on the down thrown side of the May Junction Fault. Travel time measurements were

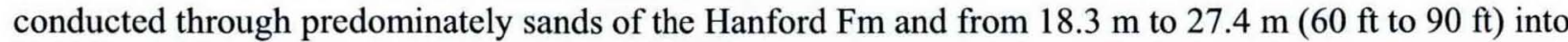
the Ringold Fm. Geologic information is not readily available for this well and is derived from Well 699$35-27$ located about $396.2 \mathrm{~m}(1,300 \mathrm{ft})$ to the southwest and at approximately the same ground surface elevation. The well currently has a total depth of about $43.3 \mathrm{~m}$ (142 ft) and check shot surveys were conducted to $43 \mathrm{~m}(141 \mathrm{ft})$.

Survey results for Well 699-36-27 are shown in Figure 31 along with the natural gamma log, driller's description and geologic names of units encountered. Seismic velocities increase from about $396.2 \mathrm{~m} / \mathrm{s}$ $(1,300 \mathrm{ft} / \mathrm{s})$ at the ground surface to $640.1 \mathrm{~m} / \mathrm{s}(2,100 \mathrm{ft} / \mathrm{s})$ near the base of the sand unit at $(12.2 \mathrm{~m} \mathrm{[40}$ $\mathrm{ft}])$. An approximately $16.8 \mathrm{~m}(55 \mathrm{ft})$ thick zone of higher velocities $(792.5 \mathrm{~m} / \mathrm{s}$ to $1219.2 \mathrm{~m} / \mathrm{s}(2,600 \mathrm{ft} / \mathrm{s}$ to $4,000 \mathrm{ft} / \mathrm{s}$ ) likely corresponds to more gravel dominated facies. Velocities decrease below $28.7 \mathrm{~m}$ (94 $\mathrm{ft})$ to $701 \mathrm{~m} / \mathrm{s}(2,300 \mathrm{ft} / \mathrm{s})$ at the top of a sand-silt sequence, increase to $1,066.8 \mathrm{~m} / \mathrm{s}(3,500 \mathrm{ft} / \mathrm{s})$ towards the base and into the upper part of a clay unit. Sediment velocities rise above $2,133.6 \mathrm{~m} / \mathrm{s}(7,000 \mathrm{ft} / \mathrm{s})$ near the water table, reflecting either the presence of a clay unit or increased saturation, or some combination of both. The change from Hanford to Ringold sediments likely marked by the zone of increased velocity near $12.2 \mathrm{~m}(40 \mathrm{ft})$ in depth.

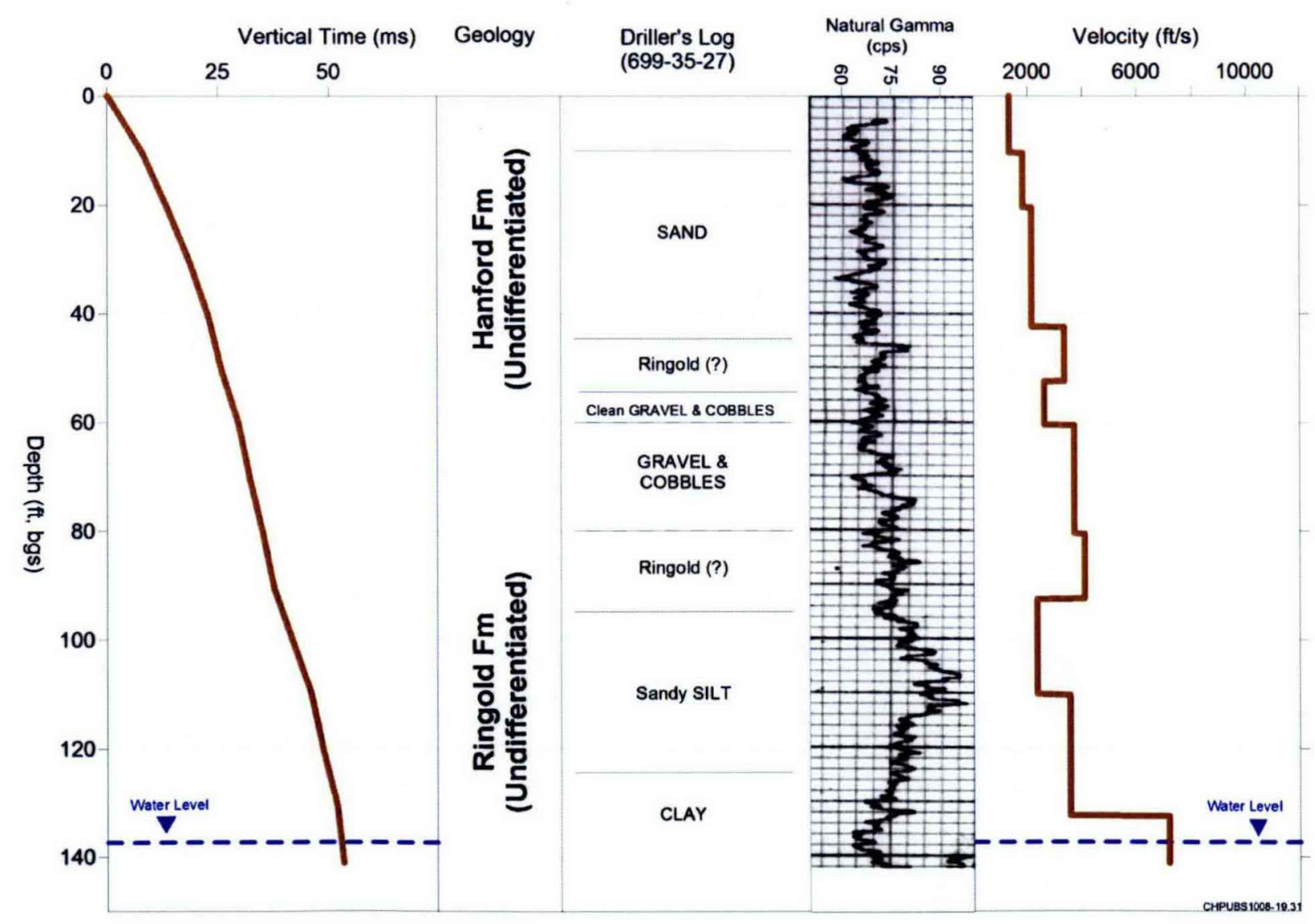

Figure 31. Check Shot Survey Results for Well 699-36-27 


\subsection{Well 699-40-33B}

Well 699-40-33B is located in the 200-PO-1 OU, about $4 \mathrm{~km}(2.5 \mathrm{mi})$ due east of the 200 East Area (see Figure 1 and Figure 3 ). Check shot surveys in this well support interpretation of BWIP seismic profile FY80-13, and provides time-depth information for Hanford and Ringold units on the up thrown side of

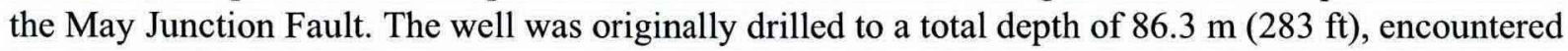

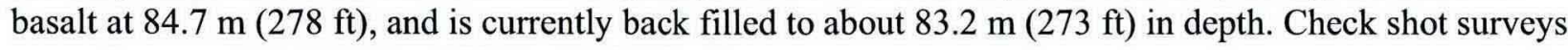
were also completed to about $83.2 \mathrm{~m}(273 \mathrm{ft})$.

Results for Well 699-40-33B are shown in Figure 32 along with the natural gamma log, the driller's description and geologic names of units encountered. The position of the Hanford-Ringold contact is not well documented, but is tentatively placed at the first mention of clay in the driller's description though this may be too low given the increase in velocity near $15.2 \mathrm{~m}(50 \mathrm{ft})$. Seismic velocities increase from about $518.2 \mathrm{~m} / \mathrm{s}(1,700 \mathrm{ft} / \mathrm{s})$ to $975.4 \mathrm{~m} / \mathrm{s}(\sim 3,200 \mathrm{ft} / \mathrm{s})$ in the upper $15.2 \mathrm{~m}(50 \mathrm{ft})$ of the well where Hanford gravels are present. Relatively higher velocities $(1,615.4 \mathrm{~m} / \mathrm{s}[5,300 \mathrm{ft} / \mathrm{s}])$ occur in a $6.1 \mathrm{~m} / \mathrm{s}(20$ $\mathrm{ft}$ ) thick zone that may correlate with a gravel and sand zone near the likely base of the Hanford Fm. The water table is at the approximate depth of a lithologic change from sand and gravel to clays. Seismic velocities increase slightly across this interface $(1,502.7 \mathrm{~m} / \mathrm{s}(4,930 \mathrm{ft} / \mathrm{s})$ above to $1589.5 \mathrm{~m} / \mathrm{s}(5,215 \mathrm{ft} / \mathrm{s})$ below). Within the basal part of the Ringold sediment column, seismic velocities increase to 2,529.8 m/s $(8,300 \mathrm{ft} / \mathrm{s})$ and $2,987 \mathrm{~m} / \mathrm{s}(9,800 \mathrm{ft} / \mathrm{s})$, perhaps indicating greater induration and consolidation of the gravel clay and gravel units.

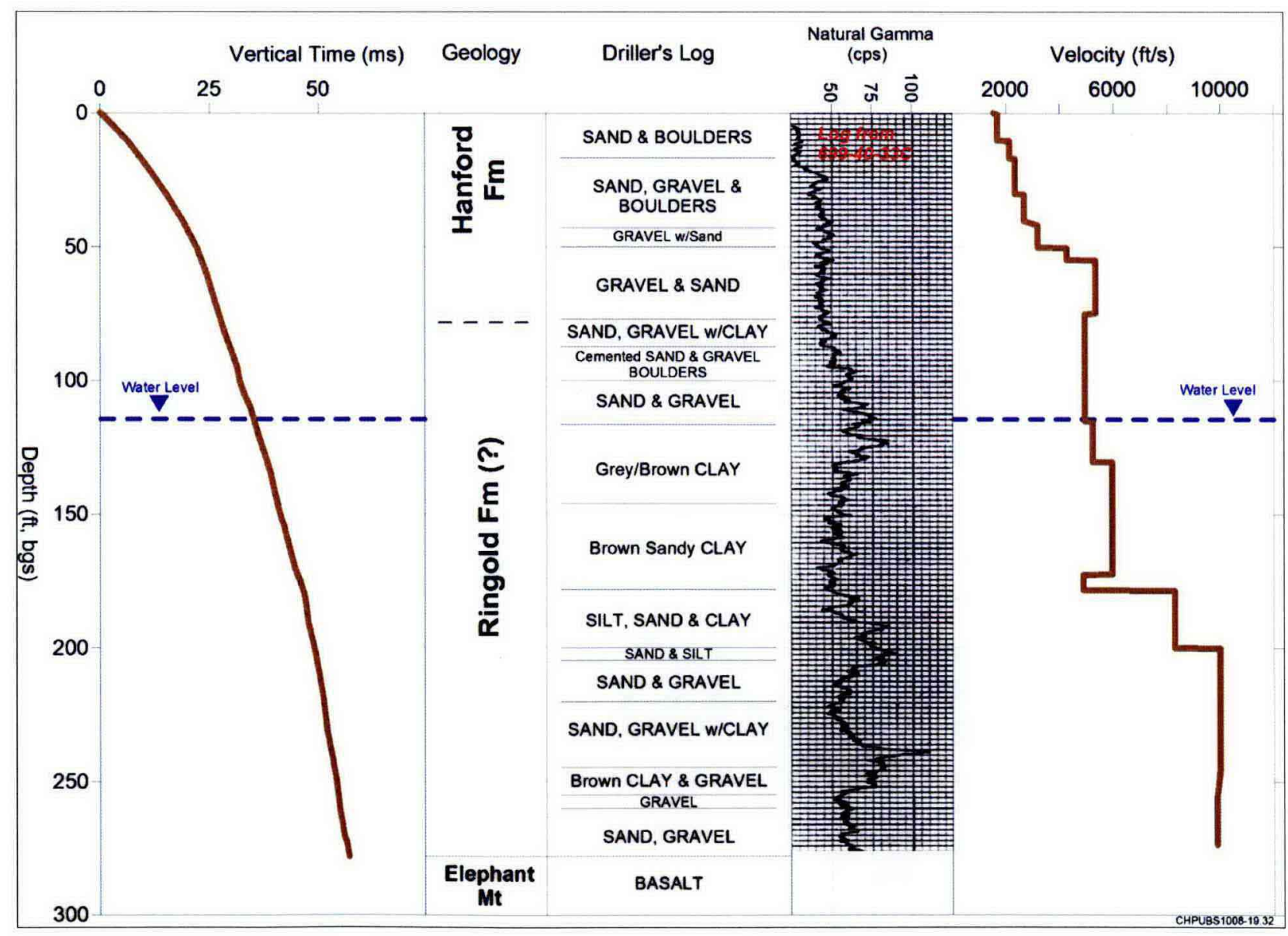

Figure 32. Check Shot Survey Results for Well 699-40-33B 


\subsection{Well 699-49-21}

Well 699-49-21 is located along Route 11A approximately $8 \mathrm{~km}(5 \mathrm{mi})$ east of 200 East (see Figure 1 and Figure 3). The well is sited over the top of the southeast plunging Gable Mt anticlinal structure and provides time-depth information to support interpretation of BWIP seismic profiles FY79-03 and FY7902. Travel time measurements were conducted through sands and gravels of the Hanford Fm, though the driller's log indicates a weathered lithic tuff near base of the well. The well was originally completed to a

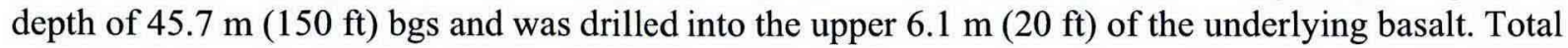
well depth is currently about $34.4 \mathrm{~m}(113 \mathrm{ft})$ and check shot surveys were conducted to a depth of $34.2 \mathrm{~m}$ $(112 \mathrm{ft})$, which is about $5.5 \mathrm{~m}(18 \mathrm{ft})$ higher than the top-of-basalt.

Figure 33 summarizes results for Well 699-49-21 along with the natural gamma log, the driller's description and geologic names of units encountered. Seismic velocities increase monotonically with depth, starting at approximately $518.2 \mathrm{~m} / \mathrm{s}(1,700 \mathrm{ft} / \mathrm{s})$ near the surface to about $1,097.3 \mathrm{~m} / \mathrm{s}(3,600 \mathrm{ft} / \mathrm{s})$ at

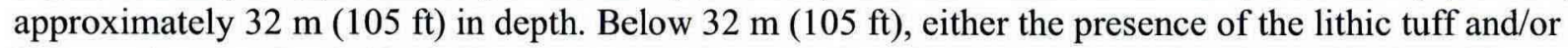
increased saturation is likely the cause of the increase in velocity to about $1,439.5 \mathrm{~m} / \mathrm{s}(4,900 \mathrm{ft} / \mathrm{s})$.

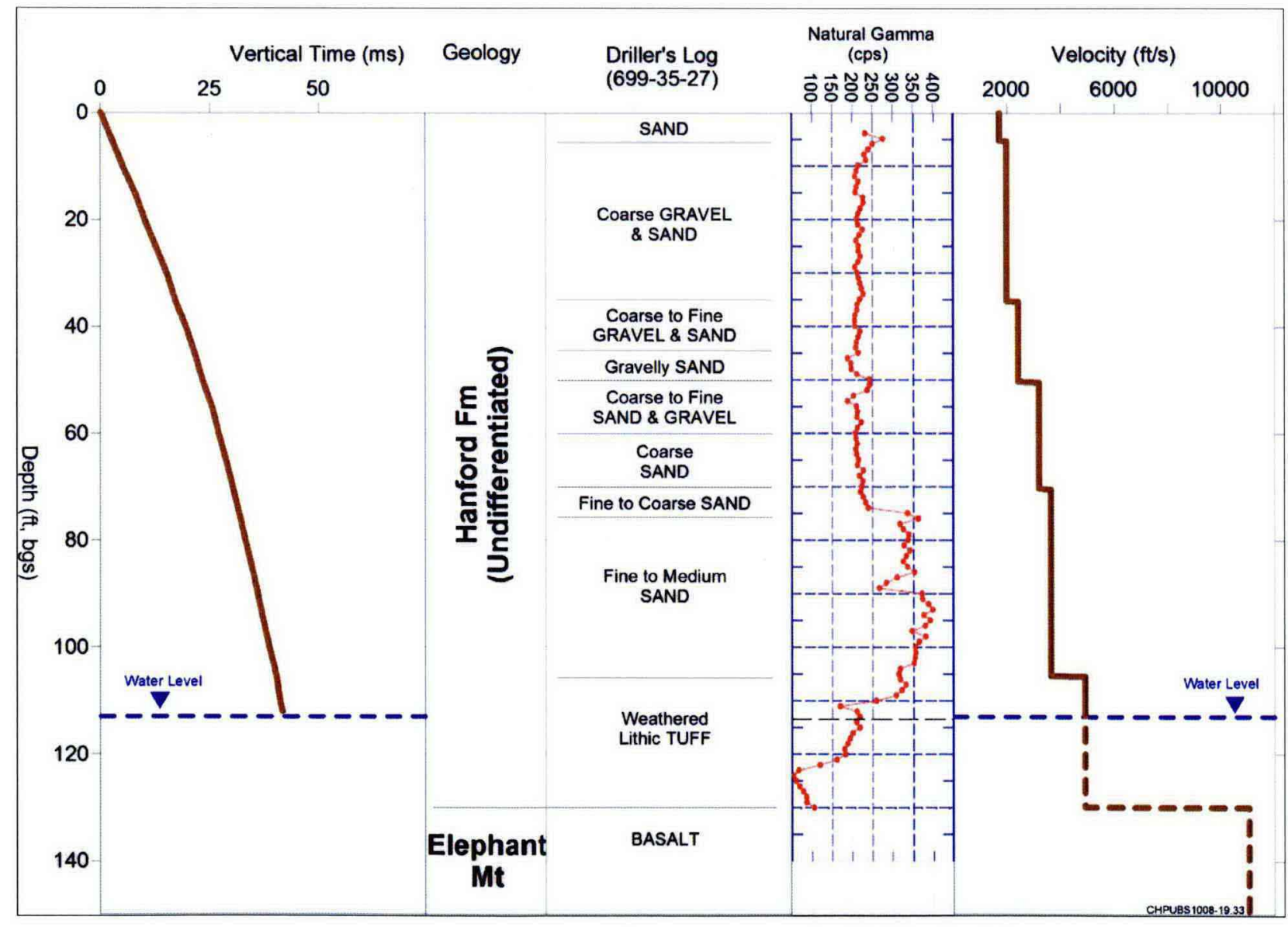

Figure 33. Check Shot Survey Results for Well 699-49-21

\subsection{Well 699-50-59}

Well 699-50-59 is located in the Gable Gap region and is part of 200-BP-5. The well is about $243.8 \mathrm{~m}$ $(800 \mathrm{ft})$ west of the intersection of Route 11A and Route 4N (see Figure 1 and Figure 4). Check shot surveys in this well provide time-depth information to support interpretation of BWIP profiles FY79-03 
and FY80-12, and Landstreamer profile FY09-L-1A. Travel time measurements were conducted through predominantly gravels of the Hanford Fm and into the upper few feet of the underlying Elephant Mt basalt. The well was originally drilled to $53 \mathrm{~m}$ (174 ft) in depth, and encountered basalt near $50.9 \mathrm{~m} \mathrm{(167}$ $\mathrm{ft})$. Check shot surveys were completed to $52.1 \mathrm{~m}(171 \mathrm{ft})$.

Results for Well 699-50-59 are shown in Figure 34 along with the associated gamma log and driller's description and geologic names of units encountered. Seismic velocity of the near-surface material is about $457.2 \mathrm{~m} / \mathrm{s}(1,500 \mathrm{ft} / \mathrm{s})$, and increases monotonically with depth to about $21.3(70 \mathrm{ft})$ where the seismic velocity of the upper gravel zone is approximately $1,158.2 \mathrm{~m} / \mathrm{s}(3,800 \mathrm{ft} / \mathrm{s})$. Below $21.3 \mathrm{~m}(70 \mathrm{ft})$, seismic velocities range from $914.4 \mathrm{~m} / \mathrm{s}(3,000 \mathrm{ft} / \mathrm{s})$ to $1,158.2 \mathrm{~m} / \mathrm{s}(3,800 \mathrm{ft} / \mathrm{s})$ until the basalt is encountered. The estimated seismic velocity of $\sim 3,139.4 \mathrm{~m} / \mathrm{s}(\sim 10,300 \mathrm{ft} / \mathrm{s})$ for the basalt is rather tenuous

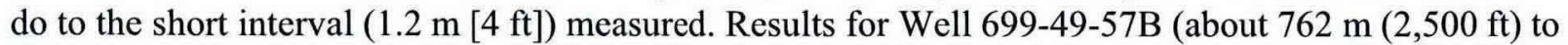
the east-southeast) are significantly higher $(5,212.1 \mathrm{~m} / \mathrm{s}[17,100 \mathrm{ft} / \mathrm{s}])$; however, surveys through the approximately $15.2 \mathrm{~m}(50 \mathrm{ft})$ thick section of basalt in Well 699-52-55B indicate a slightly slower basalt velocity of $(2,708.1 \mathrm{~m} / \mathrm{s}(8,885 \mathrm{ft} / \mathrm{s})$.

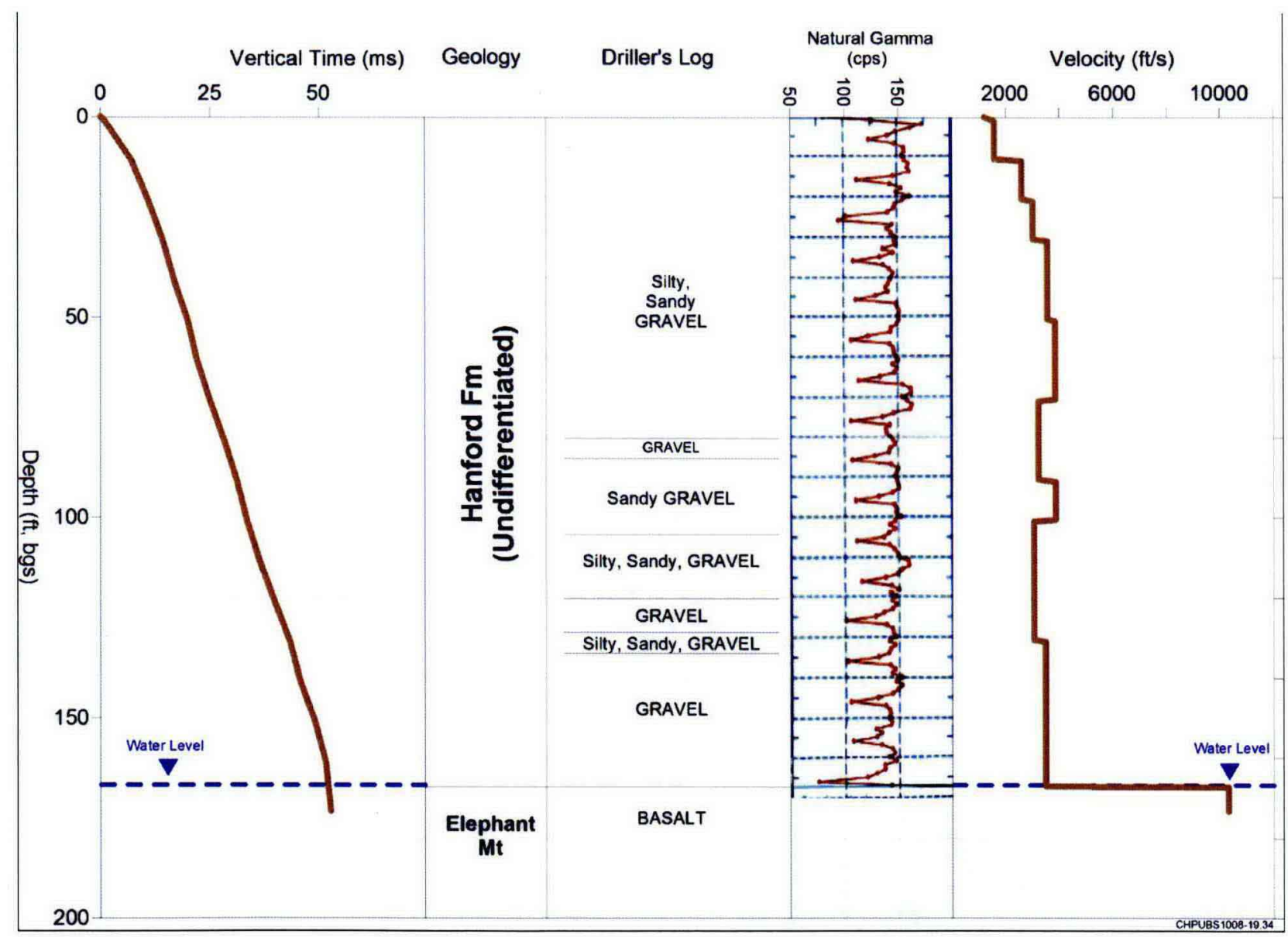

Figure 34. Check Shot Survey Results for Well 699-50-59

\subsection{Well 699-52-55}

Well 699-52-55 is located in the Gable Gap region within the 200-BP-5 OU. The well is located about

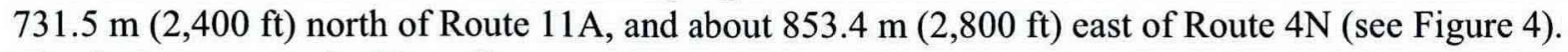

Check shot surveys in this well support interpretation of Landstreamer seismic line FY09-L-3 with travel 
time measurements conducted through sand and gravels of the Hanford Fm and into the underlying

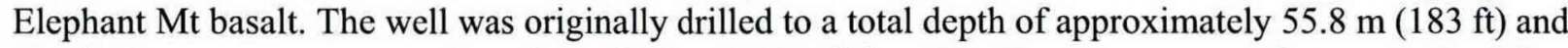
check shot surveys were conducted to $\sim 55.2 \mathrm{~m}(\sim 181 \mathrm{ft})$ bgs. Basalt was encountered at approximately $53.9 \mathrm{~m}(177 \mathrm{ft})$ bgs.

Results for Well 699-52-55 are summarized in Figure 35 along with the natural gamma log, the driller's description and geologic names of units encountered. Seismic velocities within the upper 51.8 (170 ft) of the well range from $609.6 \mathrm{~m} / \mathrm{s}(2,000 \mathrm{ft} / \mathrm{s})$ to $1,127.8 \mathrm{~m} / \mathrm{s}(3,700 \mathrm{ft} / \mathrm{s})$, and can be loosely correlated with

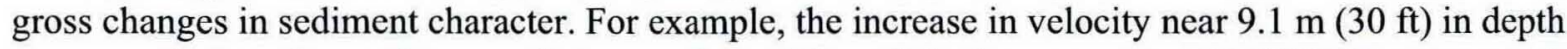
corresponds to a change from sands to gravels, and the subtle decrease near 45.7 (150 ft) corresponds to an increase in silt content (note the gamma log response).

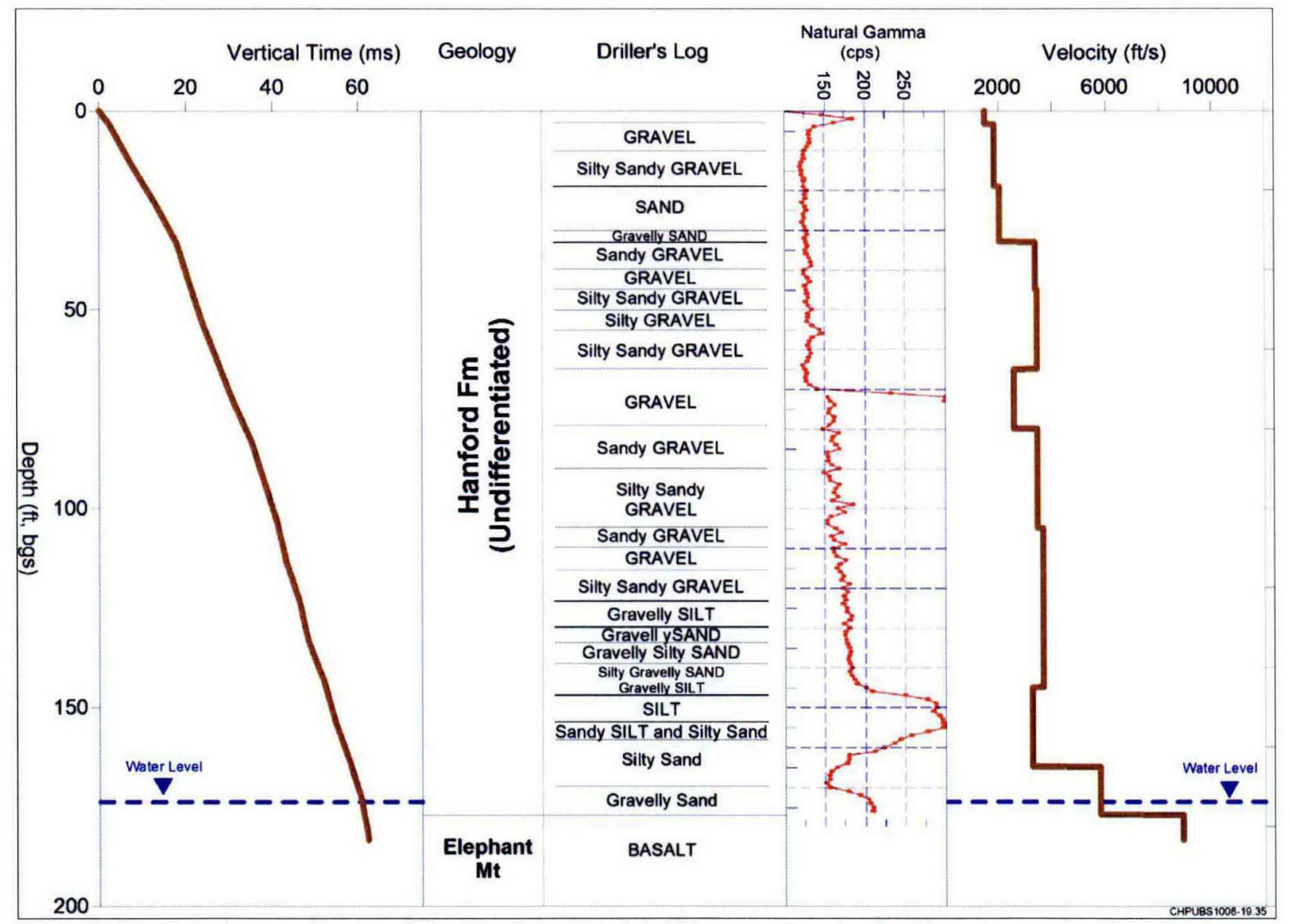

Figure 35. Check Shot Survey Results for Well 699-52-55

Estimates of the seismic velocity for the basalt remain tenuous due to the short section afforded by the well ( $<1.8 \mathrm{~m}[6 \mathrm{ft}]$ ). Results for Well $699-52-55 \mathrm{~B}$ (about $3 \mathrm{~m}[10 \mathrm{ft}]$ to the south) indicate a relatively slow seismic velocity of $\sim 2,575.6 \mathrm{~m} / \mathrm{s}(\sim 8450 \mathrm{ft} / \mathrm{s})$ which is used for this well for plotting and display purposes.

\subsection{Well 699-52-55B}

Well 699-52-55B is located in the Gable Gap region within the 200-BP-5 OU (see Figure 1 and Figure 4). The well is located about $731.5 \mathrm{~m}(2,400 \mathrm{ft})$ north of Route $11 \mathrm{~A}$, and about $853.4 \mathrm{~m}(2,800 \mathrm{ft})$ east of Route 4N (see Figure 4). Check shot surveys in this well support interpretation of Landstreamer seismic line FY09-L-3 with travel time measurements conducted through sand and gravels of the Hanford Fm, 


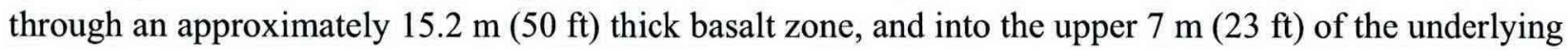

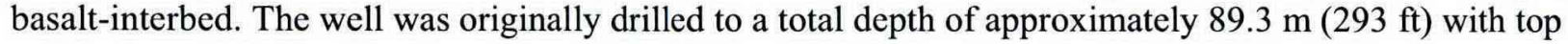
and bottom of the basalt unit encountered at $53.8 \mathrm{~m}(176.5 \mathrm{ft})$ and $67.7 \mathrm{~m}(222 \mathrm{ft})$. Check shot surveys were conducted to well bottom of $\sim 75 \mathrm{~m}(\sim 246 \mathrm{ft})$ bgs.

Results for Well 699-52-55B are shown in Figure 36 along with the driller's description and geologic names of units encountered. Also shown is the natural gamma $\log$ for $699-52-55$ (about $3 \mathrm{~m}[10 \mathrm{ft}]$ to the north). In the upper $15.2 \mathrm{~m}(50 \mathrm{ft})$, seismic velocities increase approximately $457.2 \mathrm{~m} / \mathrm{s}(1,500 \mathrm{ft} / \mathrm{s})$ to 945 $\mathrm{m} / \mathrm{s}(3,100 \mathrm{ft} / \mathrm{s})$, with changes in velocity interpreted at interfaces between gravel and sand zones, with a

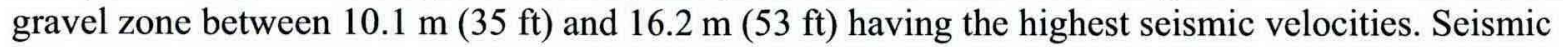

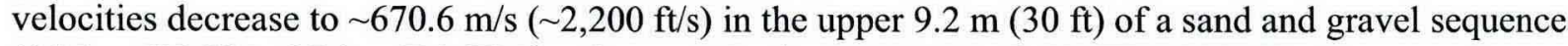

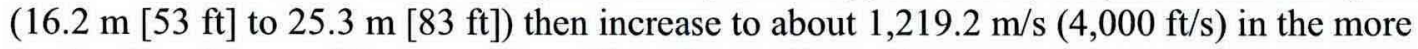
predominantly gravel lower section. Silt and gravelly sand zones from $44.2 \mathrm{~m}(145 \mathrm{ft})$ to $51.8 \mathrm{~m}(170 \mathrm{ft})$ have associated lower seismic velocities $(\sim 1,097.3 \mathrm{~m} / \mathrm{s}[3,600 \mathrm{ft} / \mathrm{s}])$.

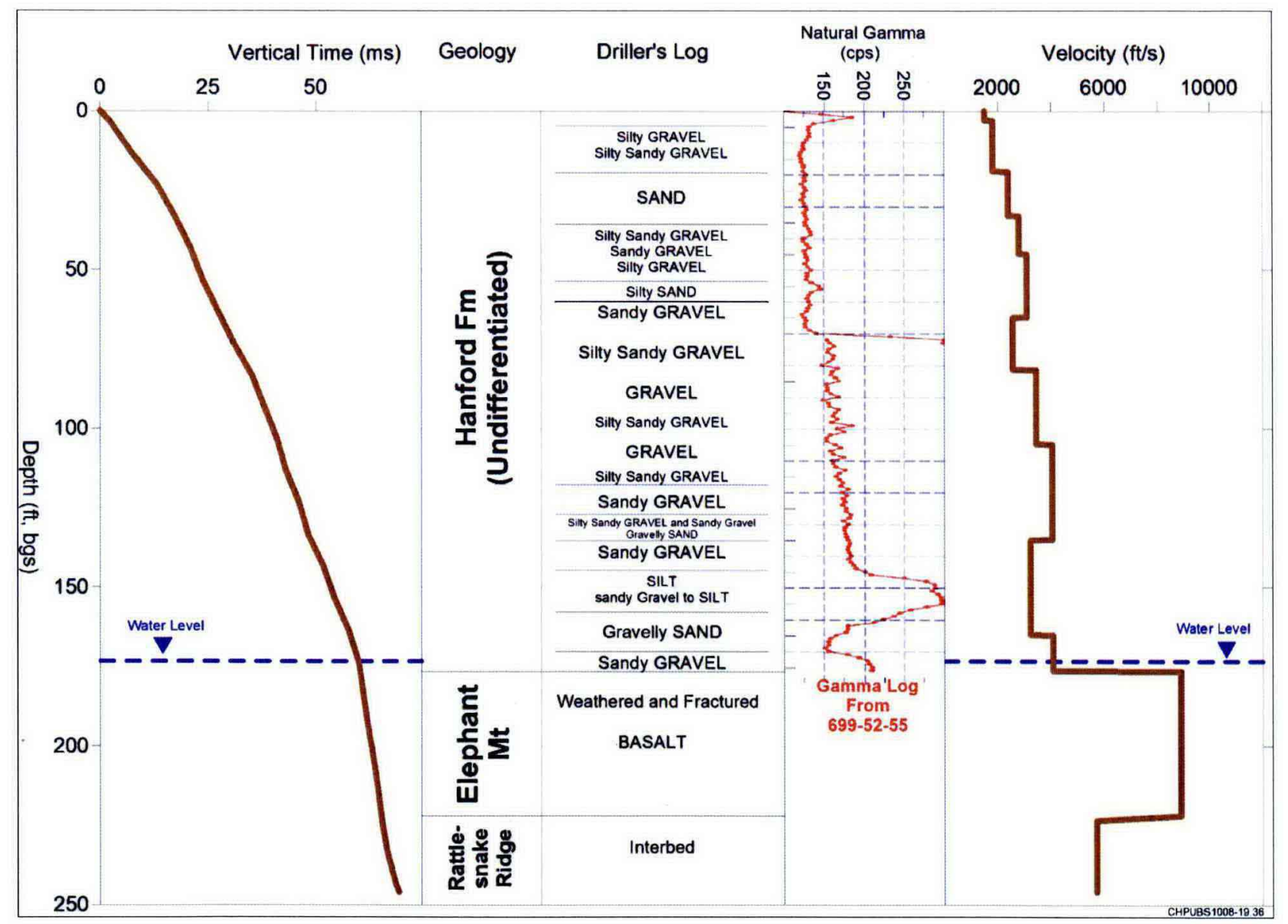

Figure 36. Check Shot Survey Results for Well 699-52-55B

A velocity of approximately $2,590.1 \mathrm{~m} / \mathrm{s}(8,500 \mathrm{ft} / \mathrm{s})$ is estimated for the $15.2 \mathrm{~m}(50 \mathrm{ft})$ section of Elephant Mt basalt sampled by the check shot survey. This is significantly lower than observed at wells 699-49-57B $(\sim 5,181.6 \mathrm{~m} / \mathrm{s}[17,000 \mathrm{ft} / \mathrm{s}])$ and 699-54-57 $(\sim 4,572 \mathrm{~m} / \mathrm{s}[15,000 \mathrm{ft} / \mathrm{s}])$, perhaps indicative of the weathering and fracturing observed in the driller/geologic log in the upper $6.1 \mathrm{~m}(20 \mathrm{ft})$. Seismic velocity of the underlying Rattlesnake Ridge interbed is estimated at approximately $1,981.2 \mathrm{~m} / \mathrm{s}(6,500$ $\mathrm{ft} / \mathrm{s})$. 


\subsection{Well 699-55-60A}

Well 699-55-60A is located in the Gable Gap region and within the 200-BP-5 OU (Figure 1 and Figure 4). The well is sited about $1.61 \mathrm{~km}(1 \mathrm{mi})$ north of the intersection of Routes $11 \mathrm{~A}$ and $4 \mathrm{~N}$, and approximately $640.1 \mathrm{~m}(2,100 \mathrm{ft}$ ) west of Route $4 \mathrm{~N}$ (see Figure 4). Check shot surveys in this well support interpretation of Landstreamer seismic lines FY09-L-2C and FY09-L-4A with travel time measurements conducted predominantly through gravels of the Hanford Fm. The well was originally drilled to a total depth of approximately $71 \mathrm{~m}(233 \mathrm{ft})$, and check shot surveys were conducted to $65.5 \mathrm{~m}$ $(215 \mathrm{ft})$ in depth.

Figure 37 summarizes results for the check shot surveys in Well 699-55-60A with a comparison to the driller's description and geologic names of units encountered. Seismic velocities increase in depth, from $487.7 \mathrm{~m} / \mathrm{s}(1600 \mathrm{ft} / \mathrm{s})$ to $\sim 1,127.8 \mathrm{~m} / \mathrm{s}(3,700 \mathrm{ft} / \mathrm{s})$, within the upper $15.2 \mathrm{~m}(50 \mathrm{ft})$ of the well. Below 15.2 $\mathrm{m}(50 \mathrm{ft})$, but above the water table, estimated seismic velocities show more variation, ranging from a low

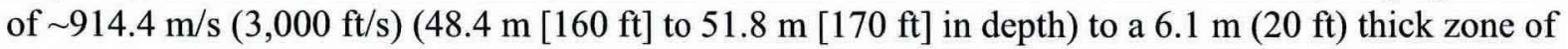
high velocity $(\sim 1,981.2 \mathrm{~m} / \mathrm{s}[6,500 \mathrm{ft} / \mathrm{s}])$ at $16.8 \mathrm{~m}$ to $22.9 \mathrm{~m}(55 \mathrm{ft}$ to $75 \mathrm{ft})$ in depth. These variations likely correspond to whether gravel or boulders dominate with higher-velocity zones corresponding to higher percentage of boulders. Below the water table, seismic velocities average about $2,133.6 \mathrm{~m} / \mathrm{s}(7,000$ $\mathrm{ft} / \mathrm{s})$ with a possible decrease to $1,828 \mathrm{~m} / \mathrm{s}(6,000 \mathrm{ft} / \mathrm{s})$ near the base of the survey.

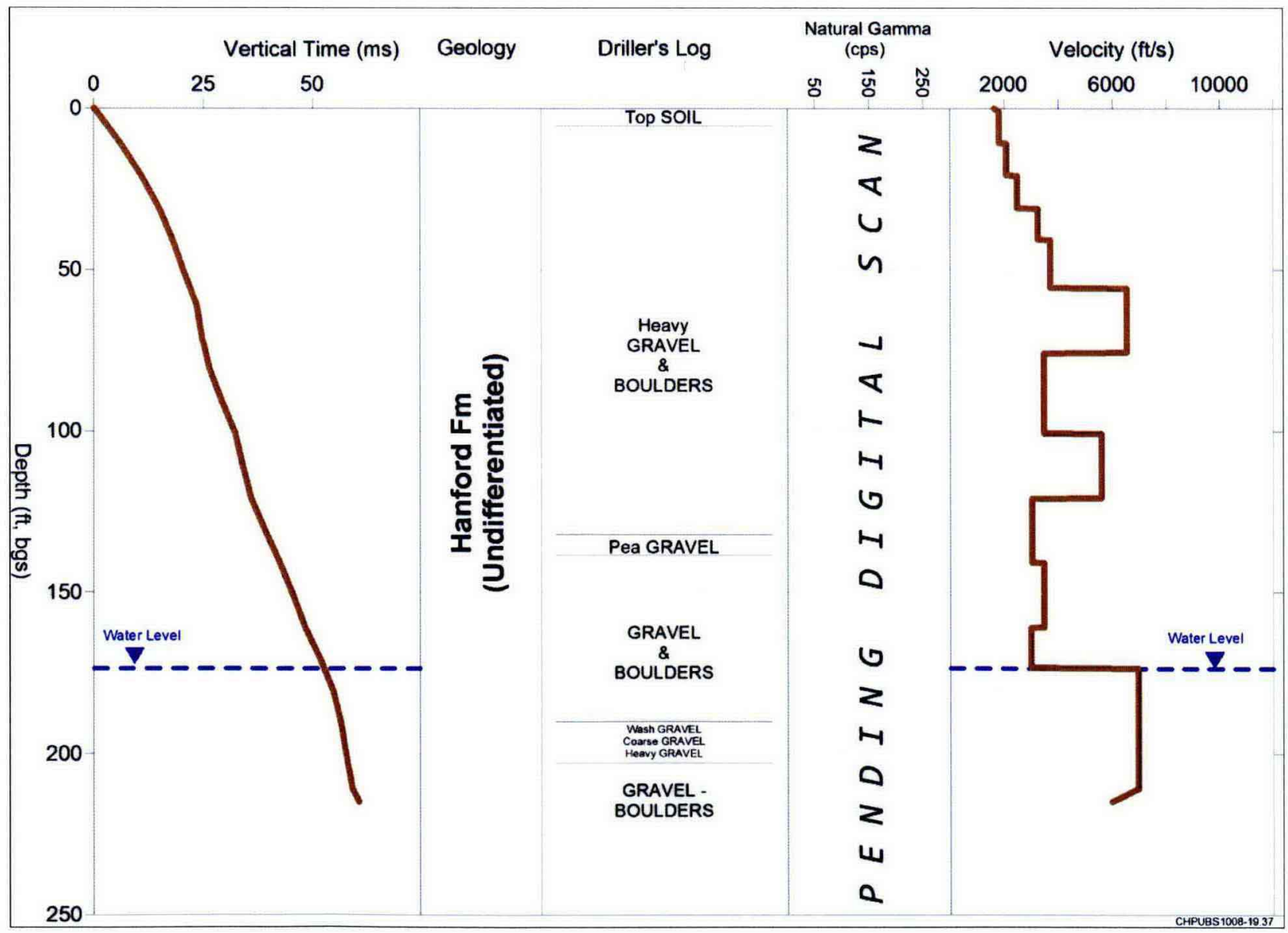

Figure 37. Check Shot Survey Results for Well 699-55-60A 


\subsection{Well 699-57-83C}

Well 699-57-83C is located along Route 6 between the 100-BC and 200 West areas, about $2.4 \mathrm{~km}(1.5$ mi) north of Route 11A (Figure 1 and Figure 5). The well is located south of the Gable Butte anticlinal structure and was installed to investigate the Columbia River basalt group. Check shot surveys support interpretation of BWIP seismic profile FY79-05. Travel time measurements were conducted through undifferentiated units of the Hanford and Ringold Fm, and into the upper part of the Elephant Mt basalt. The well was originally drilled to a total depth of approximately $1,076.9 \mathrm{~m}(3,533 \mathrm{ft})$. Check shot surveying could not be conducted beyond $173.7 \mathrm{~m}(570 \mathrm{ft})$ because the $5.1-\mathrm{cm}(2-\mathrm{in}$.) inside diameter

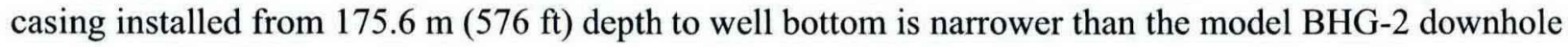
geophone. In addition, seismic energy generated by the sledgehammer source proved insufficient to investigate below $125 \mathrm{~m}(410 \mathrm{ft})$, and check shot results are presented to the upper part of the basalt unit.

Results for Well 699-57-83C are summarized in Figure 38 along with the associated gamma $\log (\mathrm{s})$, the driller's description and geologic names of units encountered. Gamma logging in 699-57-83C was only

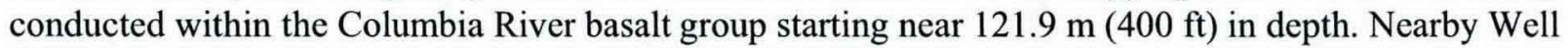
699-57-83A was gamma-logged to about $54.9 \mathrm{~m}(180 \mathrm{ft}) \mathrm{bgs}$. Detailed information regarding the position of the Hanford-Ringold contact in Well 699-57-83C was not available. The driller's description for nearby Well 699-57-83A indicates a change from conglomerate to silt-sand facies near $61 \mathrm{~m}(200 \mathrm{ft}) \mathrm{bgs}$.

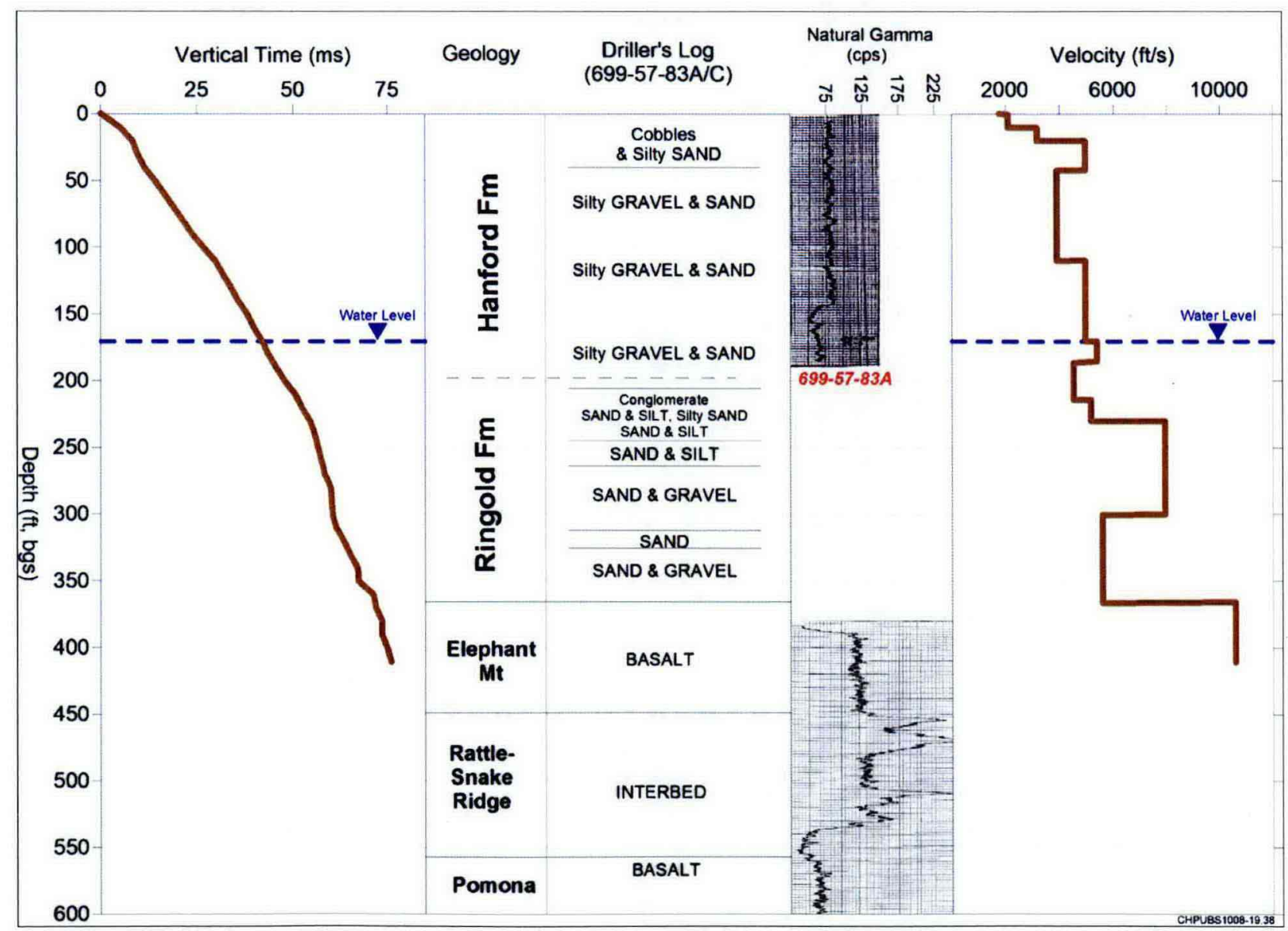

Figure 38. Check Shot Survey Results for Well 699-57-83C 
Seismic velocities rapidly increase from approximately $548.6 \mathrm{~m} / \mathrm{s}(1,800 \mathrm{ft} / \mathrm{s})$ at the ground surface to almost $1,524 \mathrm{~m} / \mathrm{s}$ at $6.1 \mathrm{~m}(5,000 \mathrm{ft} / \mathrm{s}$ at $20 \mathrm{ft})$ in depth. The underlying silty gravel and sand zone increases in velocity from $1,189 \mathrm{~m} / \mathrm{s}$ to $1,509 \mathrm{~m} / \mathrm{s}(3,900 \mathrm{ft} / \mathrm{s}$ to $4,950 \mathrm{ft} / \mathrm{s})$, with a slight increase in velocity $1,615.4 \mathrm{~m} / \mathrm{s}(5,300 \mathrm{ft} / \mathrm{s})$ across the water table. The upper part of the Ringold $(61 \mathrm{~m}$ to $70.1 \mathrm{~m}$ [200 ft to $230 \mathrm{ft}$ ]) averages about $1,524 \mathrm{~m} / \mathrm{s}(5,000 \mathrm{ft} / \mathrm{s})$ in velocity and is underlain by an approximate $21.3 \mathrm{~m}(70 \mathrm{ft})$ thick zone of high velocity $2,407.9 \mathrm{~m} / \mathrm{s}(\sim 7,900 \mathrm{ft} / \mathrm{s})$. Seismic velocity for the basalt is estimated at $3,200.4 \mathrm{~m} / \mathrm{s}(10,500 \mathrm{ft} / \mathrm{s})$.

\subsection{Well 699-61-62}

Well 699-61-62 is located in the Gable Gap region about $3.2 \mathrm{~km} \mathrm{(2} \mathrm{mi)} \mathrm{north} \mathrm{of} \mathrm{the} \mathrm{intersection} \mathrm{of} \mathrm{routes}$

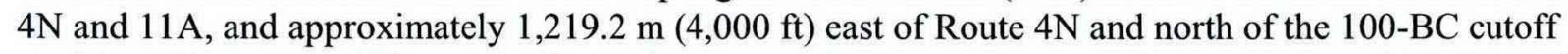
road (see Figure 1 and Figure 4). Check shot surveys in this well supports interpretation of BWIP Profile FY-79-04. Travel time measurements were conducted through sands and gravels of the Hanford Fm, and possibly the Ringold Fm. Well 699-61-62 was originally drilled to $57.3 \mathrm{~m}(188 \mathrm{ft})$ in depth and encountered basalt at $54.1 \mathrm{~m}(177.5 \mathrm{ft})$. Well construction resulted in the well being back-filled and plugged at $54.6 \mathrm{~m}$ (179 ft) and check shot surveys were conducted to a depth of $\sim 53.6 \mathrm{~m}(\sim 176 \mathrm{ft})$.

Figure 39 summarizes check shot survey results for Well 699-61-62 and also shown are the names of geologic units encountered and the driller's description. Seismic velocities increase with depth, starting at approximately $457.7 \mathrm{~m} / \mathrm{s}(1,600 \mathrm{ft} / \mathrm{s})$ near the surface to about $1,066.8 \mathrm{~m} / \mathrm{s}(3,500 \mathrm{ft} / \mathrm{s})$ at approximately $3.66 \mathrm{~m}(12 \mathrm{ft})$ in depth. Below $6.1 \mathrm{~m}(20 \mathrm{ft})$, seismic velocities for the Hanford gravels and sands range from $762 \mathrm{~m} / \mathrm{s}(2,500 \mathrm{ft} / \mathrm{s})$ in a sand zone from $13.7 \mathrm{~m}$ to $15.2 \mathrm{~m}(45 \mathrm{ft}$ to $50 \mathrm{ft})$ to $1,402.1 \mathrm{~m} / \mathrm{s}(4,600 \mathrm{ft} / \mathrm{s})$ in a gravel zone at $22.9 \mathrm{~m}$ to $30.5 \mathrm{~m}(75 \mathrm{ft}$ to $100 \mathrm{ft})$. The Hanford-Ringold contact likely occurs below the water table where seismic velocities range from $2,103.12 \mathrm{~m} / \mathrm{s}$ to $2,255.52 \mathrm{~m} / \mathrm{s}(6,900 \mathrm{ft} / \mathrm{s}$ to $7,400 \mathrm{ft} / \mathrm{s})$.

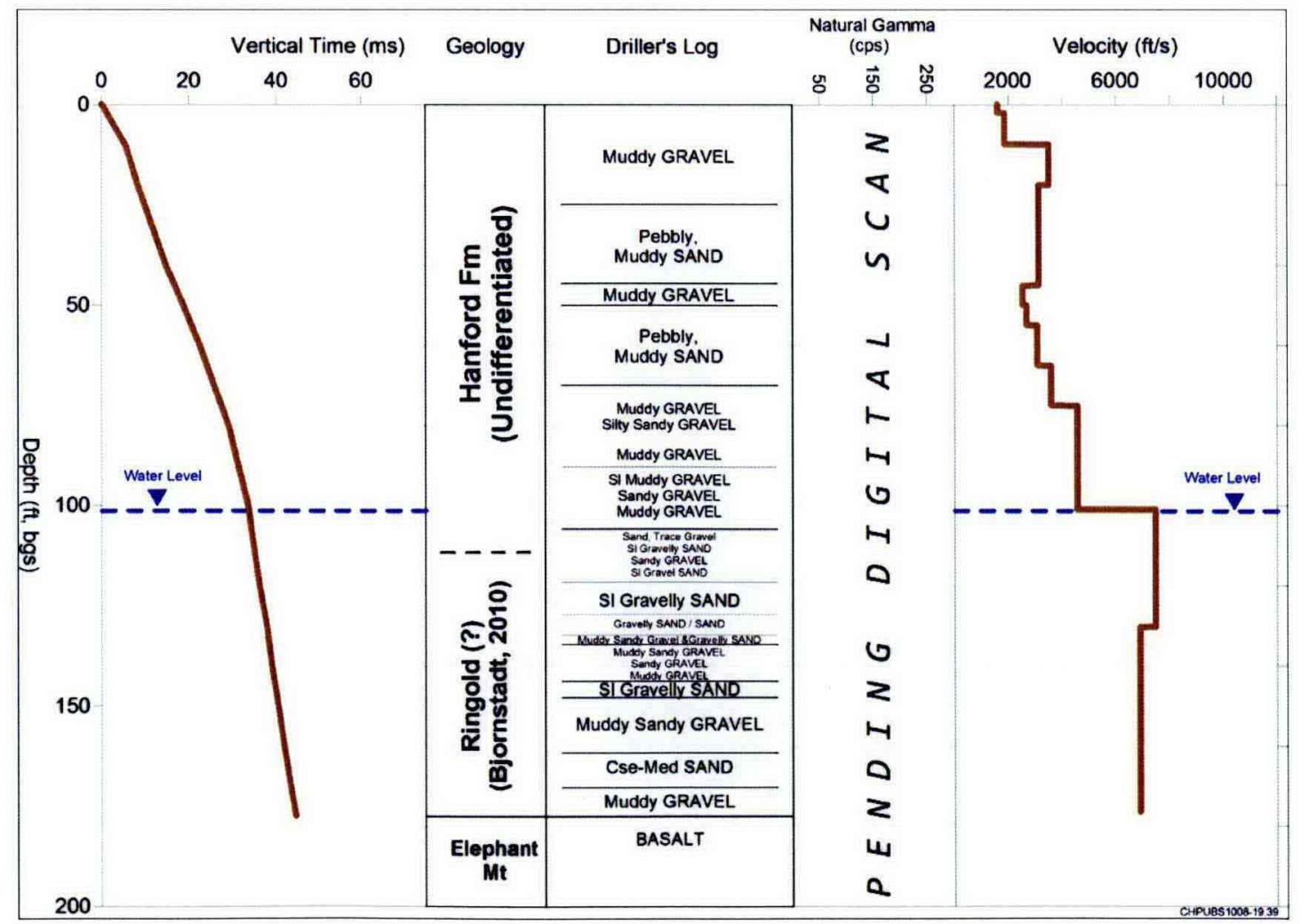

Figure 39. Check Shot Survey Results for Well 699-61-62 


\subsection{Well 699-63-58}

Well 699-63-58 is located in the Gable Gap region along Route $4 \mathrm{~N}$ about $4 \mathrm{~km}(2.5 \mathrm{mi})$ north of the intersection of routes $11 \mathrm{~A}$ and $4 \mathrm{~N}$. The well is sited on the northern flank of the Gable Mt structure and serves to support interpretation of BWIP seismic profile FY79-04 and Landstreamer profile FY09-L-3 (see Figure 1 and Figure 4). Check shot surveys were conducted through sand, gravel, and cobbles of the Hanford Fm, and into the upper $3 \mathrm{~m}(10 \mathrm{ft})$ of the underlying Elephant Mt basalt. The well was originally

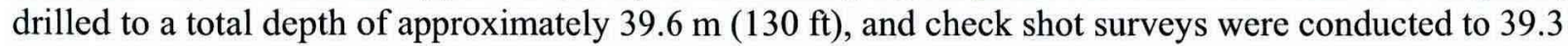
$\mathrm{m}(129 \mathrm{ft})$ in depth.

Results for Well 699-63-58 are shown in Figure 40 along with the driller's description and geologic names of units encountered. Seismic velocities increase monotonically with depth in the upper $12.2 \mathrm{~m}$ (40 $\mathrm{ft})$, starting at approximately $411.5 \mathrm{~m} / \mathrm{s}(1,350 \mathrm{ft} / \mathrm{s})$ near the surface to about $823 \mathrm{~m} / \mathrm{s}(2,700 \mathrm{ft} / \mathrm{s})$ at $9.1 \mathrm{~m}$ to $12.2 \mathrm{~m}$ (30 ft to $40 \mathrm{ft})$. Below $12.2 \mathrm{~m}(40 \mathrm{ft})$, an approximate $12.2 \mathrm{~m}(40 \mathrm{ft})$ thick sequence of sand, gravel and cobble has a seismic velocity of approximately $1,036.3 \mathrm{~m} / \mathrm{s}(3,400 \mathrm{ft} / \mathrm{s})$, and sediment near and below the water level shows an increased seismic velocity of approximately $1,493.5 \mathrm{~m} / \mathrm{s}(4,900 \mathrm{ft} / \mathrm{s})$. The low velocity of $2,651.8 \mathrm{~m} / \mathrm{s}(8,700 \mathrm{ft} / \mathrm{s})$ estimated for the basalt is only based on three measurements in the upper $3 \mathrm{~m}(10 \mathrm{ft})$, but is consistent with results obtained in Well 699-52-55B.

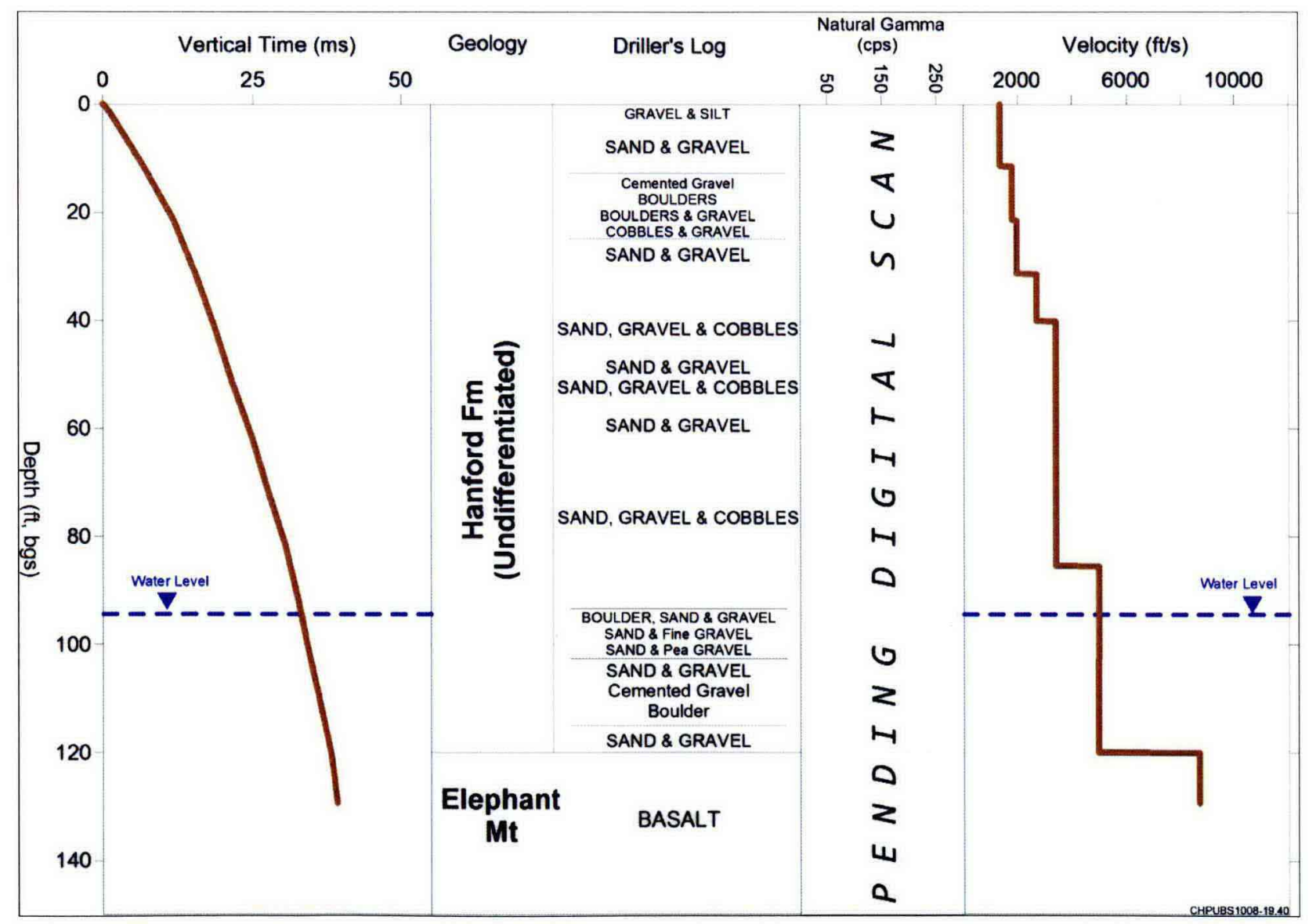

Figure 40. Check Shot Survey Results for Well 699-63-58 


\subsection{Well 699-65-83}

Well $699-65-83$ is located south of $100-\mathrm{BC}$ and about $2.4 \mathrm{~km}(1.5 \mathrm{mi})$ south of the Columbia River. The well is sited on the northern flank of the Gable Butte structure and serves to support interpretation of BWIP seismic profile FY79-05 (see Figure 1 and Figure 5). Travel time measurements in this well were conducted through sands and gravels of the Hanford Fm to a depth of approximately $34.4 \mathrm{~m}(113 \mathrm{ft})$. The well was originally drilled to a depth of $36.9(121 \mathrm{ft})$ and top-of-basalt is estimated to be $41.2 \mathrm{~m}$ to $45.8 \mathrm{~m}$ $(135 \mathrm{ft}$ to $150 \mathrm{ft})$ in depth.

Check shot results are shown in Figure 41 along with the associated gamma log and driller's description and geologic names of units encountered. Sand and gravel units in the upper $21.3 \mathrm{~m}(70 \mathrm{ft})$ have estimated velocities ranging from $1,800 \mathrm{ft} / \mathrm{s}$ to $2,500 \mathrm{ft} / \mathrm{s}$. Below $21.3 \mathrm{~m} \mathrm{(70} \mathrm{ft),} \mathrm{seismic} \mathrm{velocities} \mathrm{increase} \mathrm{to}$ $\sim 1,219.2 \mathrm{~m} / \mathrm{s}(\sim 4,000 \mathrm{ft} / \mathrm{s})$ above the water table and $2,072.6 \mathrm{~m} / \mathrm{s}(6,800 \mathrm{ft} / \mathrm{s})$ below the water table.

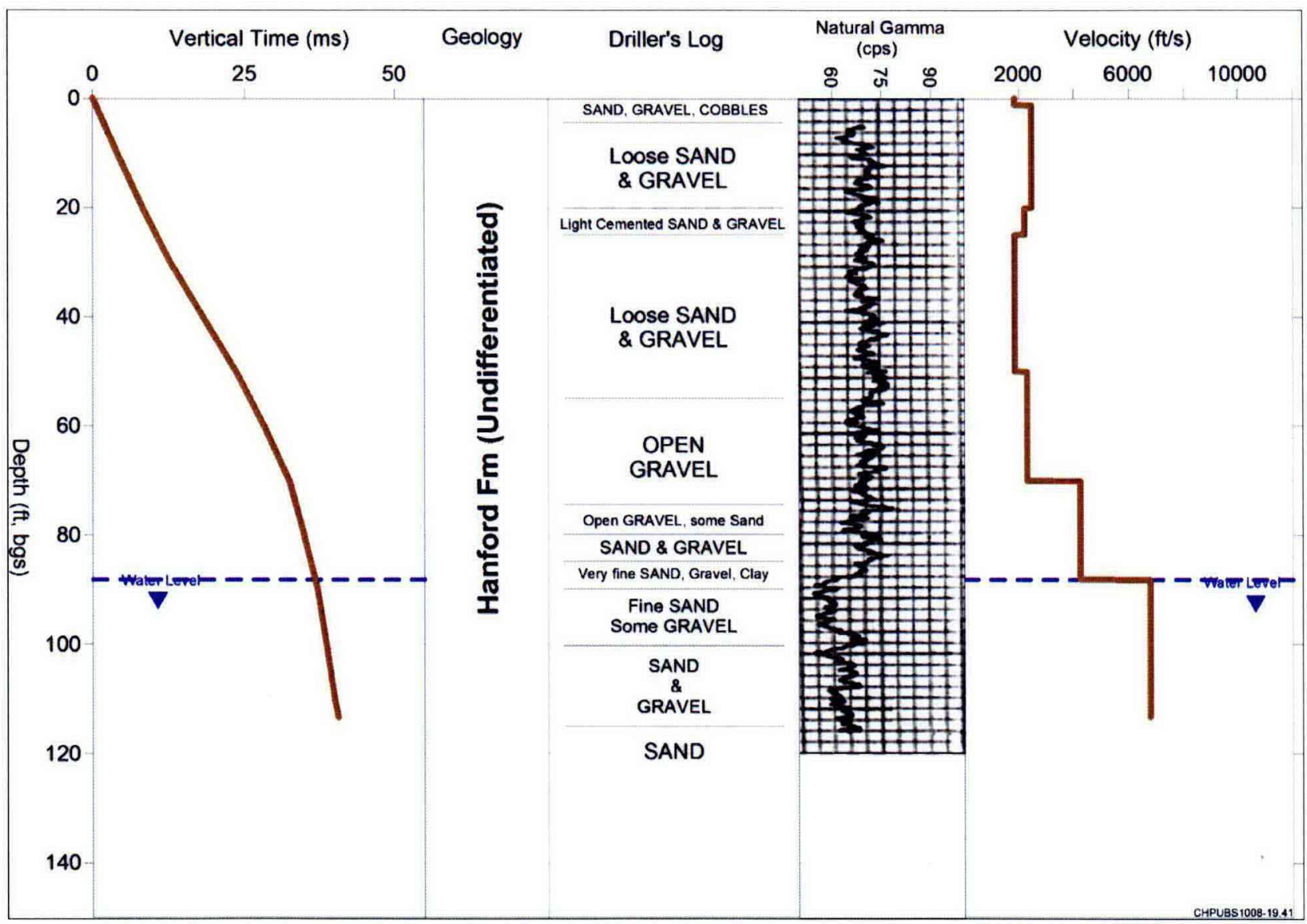

Figure 41. Check Shot Survey Results for Well 699-65-83

\section{Discussion}

Seismic velocity estimates obtained in the 29 wells are summarized in Figure 42 and Figure 43 in an attempt to identify whether velocity can be used as a diagnostic tool for differentiating the sediment facies at Hanford. In Figure 42, check shot derived velocities are plotted by well, geologic unit, and grouped into regional areas. At this time, derived velocities are only categorized by major geologic unit (Hanford, Ringold, and Basalt) and by whether the unit is above or below water table (unsaturated versus saturated). 
It is a concern that velocity for a true sandy-gravel not be compared with that of a gravelly-sand where both units are listed by the drilling description as gravels and sands).

Seismic velocity for the unsaturated Hanford sediments in Figure 42 are predominantly below 1,066.8 $\mathrm{m} / \mathrm{s}(3,500 \mathrm{ft} / \mathrm{s})$, with higher derived values of $1,158.2 \mathrm{~m} / \mathrm{s}$ to $1,920.2 \mathrm{~m} / \mathrm{s}(3,800 \mathrm{ft} / \mathrm{s}$ to $6,300 \mathrm{ft} / \mathrm{s})$ found in eight wells, with 699-26-15C and 699-55-60A yielding the highest values. Unsaturated Ringold units have velocities that are generally higher than Hanford, though significant overlap in range occurs in Wells 699-50-30 and 699-36-27. Velocities derived for saturated sediments for both the Hanford and Ringold Fms cluster in the $1,341.1 \mathrm{~m} / \mathrm{s}$ to $2,590.8 \mathrm{~m} / \mathrm{s}(4,400 \mathrm{ft} / \mathrm{s}$ to $8,500 \mathrm{ft} / \mathrm{s})$ range. Significant overlap is observed, however, for Wells 699-57-83 and 699-26-15C.

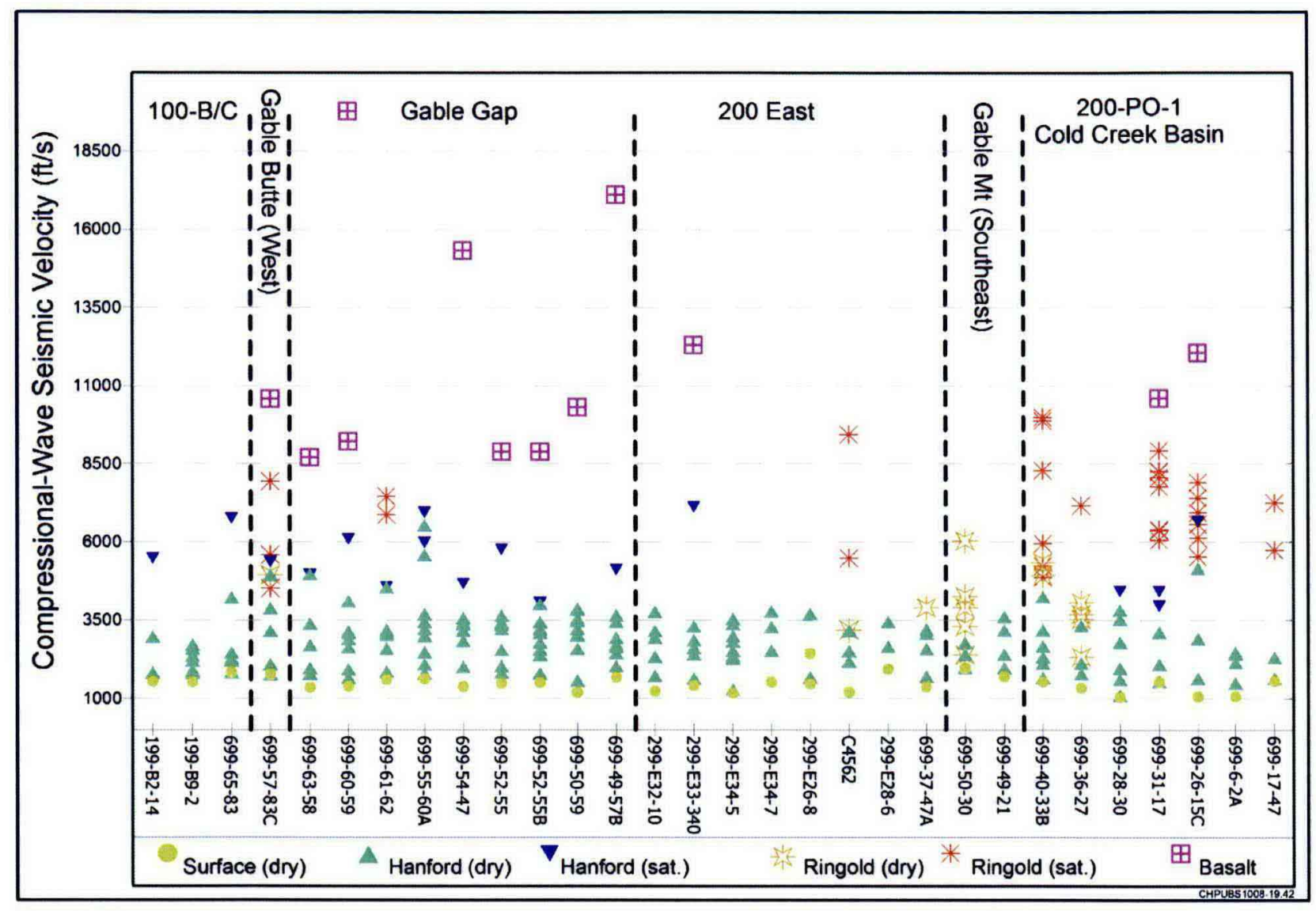

Figure 42. Seismic Velocities: 29 Check Shot Surveys, Fiscal Year 2008 to Fiscal Year 2010

Figure 43 summarizes statistical parameters (mean, standard deviation, etc) of the lithology and velocity information with the statistics table shown in the upper-left corner of the figure. Shown are the total range (minimum to maximum), the arithmetic average, median value, short-horizontal bars representing a standard deviation above and below the average of the mean and median, and normalized histograms of the velocities of saturated and unsaturated sediments (upper left corner). As expected, a clear separation between saturated and unsaturated sediment velocity occurs (velocity histograms) and confirms that seismic surveys should be able to detect the water table at Hanford in the sedimentary column. 


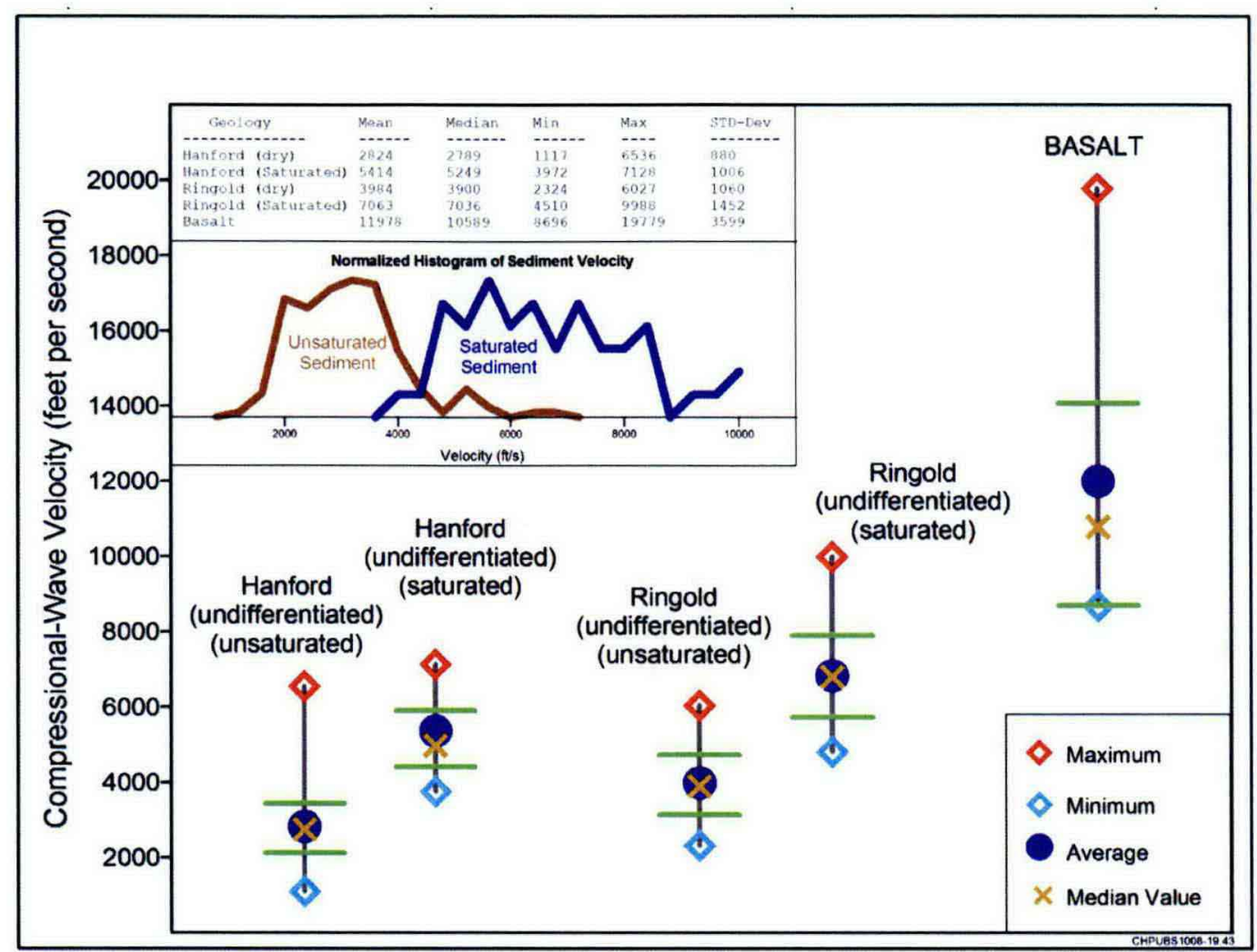

Figure 43. Seismic Velocities: 29 Check Shot Surveys, Fiscal Year 2008 to Fiscal Year 2010

Less certain is whether seismic velocity can solely be used to differentiate Hanford and Ringold units. Results from the check shot surveys suggest that Ringold (unsaturated) could be misidentified as Hanford (saturated) (or vice versa) if the position of the water table is not known (or used in the interpretation). Direct comparison of unsaturated Hanford and Ringold seismic velocities indicate an approximate 457.2 $\mathrm{m} / \mathrm{s}$ to $609.6 \mathrm{~m} / \mathrm{s}(1,500 \mathrm{ft} / \mathrm{s}$ to $2,000 \mathrm{ft} / \mathrm{s})$ overlap between dominant velocities of both units, with Ringold sediments on average being about $457.2 \mathrm{~m} / \mathrm{s}(1,500 \mathrm{ft} / \mathrm{s})$ higher in velocity than Hanford units. The case for saturated sediments is even worse in terms of differentiation by seismic velocity, as the presence of water in unconsolidated coarse-grained sediments is the primary control governing the resulting velocity. Higher derived velocities within the saturated Ringold units are most likely the result of consolidation and induration where the cohesive matrix begins dominating the resulting seismic velocity.

A final caution must also be issued if blindly interpreting "high-velocities" as basalt. Derived velocities for Ringold units range up to $\sim 3,048 \mathrm{~m} / \mathrm{s}(\sim 10,000 \mathrm{ft} / \mathrm{s})$ and for basalt intervals, seismic velocities range as low as $\sim 2,651.8 \mathrm{~m} / \mathrm{s}(\sim 8,700 \mathrm{ft} / \mathrm{s})$. This yields the distinct possibly of a seismic reflector from an indurated Ringold unit with a high-velocity being incorrectly identified as top-of-basalt on a seismic section. Check shot information, with its strong tie to well bore geology, allows correlating seismic reflectors or interfaces against the underlying geology.

Examples of how specific geologic units are correlated with seismic sections using check shot information are shown in Figure 44 for short segments of FY 2009 and FY 2008 seismic profiles and BWIP profile FY79-02. Shown on each seismic section are the resulting velocity-time curves computed from the check shot survey information. For all three cases, the basalt surface is represented by strong reflectors that correlate with a sharp increase in interval velocity - from $914.4 \mathrm{~m} / \mathrm{s}$ to $1,981.2 \mathrm{~m} / \mathrm{s}(3,000$ to $6,500 \mathrm{ft} / \mathrm{s})$ above (sediment) to $3,048 \mathrm{~m} / \mathrm{s}(10,000 \mathrm{ft} / \mathrm{s})$ and greater for the basalt. For the FY 2009 
seismic data, strong reflectors correlate with top-of-basalt as indicated by the check shot survey in Well 699-54-47. Top of basalt is indicated in the FY 2008 seismic data, and subtle changes in interval velocity within the sedimentary column appears to be loosely correlated with changes in seismic character, and tied to Hanford Fm sub-units. Time-depth information from Well 699-26-15C is used to correlate Ringold units with relatively strong reflectors that occur above the basalt surface.

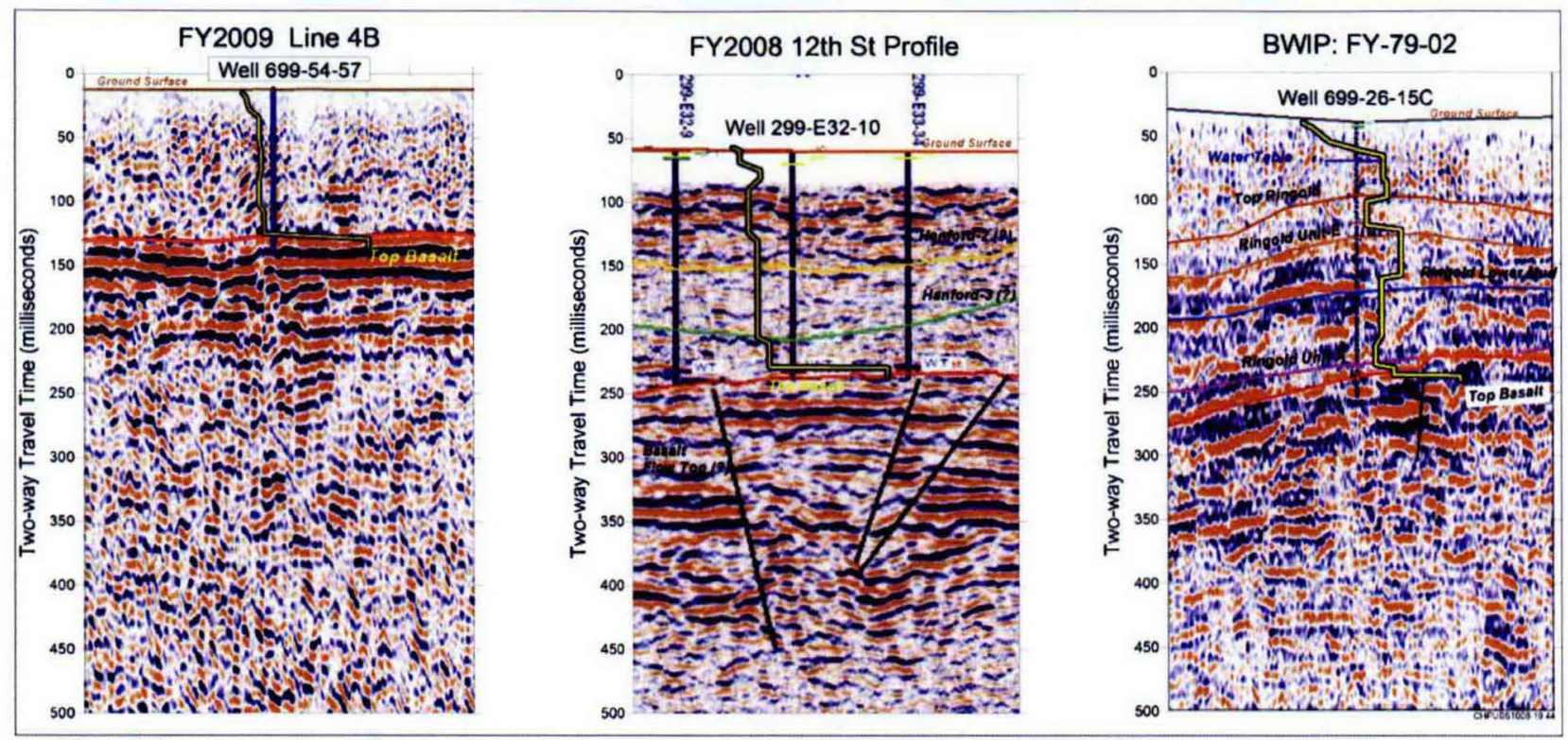

Figure 44. Check Shot Surveys, Geologic Units, and Seismic Reflectors

Figure 45 through Figure 47 are pseudo cross-sections showing changes in velocity for the 200 East, Gable Gap, and Cold Creek Basin (200-PO-1 OU) regions. Shown on each figure are the current position of the water table (dashed blue line), the top-of-basalt (dashed gray line), and an inset base map showing the cross-section line. These cross-sections illustrate both the vertical and horizontal variability in seismic velocity that can be expected at the Hanford Site. The 200 East cross-section suggests that seismic velocities for the unsaturated Hanford units are in the $762 \mathrm{~m} / \mathrm{s}$ to $1,158.2 \mathrm{~m} / \mathrm{s}(2,500 \mathrm{ft} / \mathrm{s}$ to-3,800 ft/s) range and that low-contrast (weak) reflection character should dominate the reflection sections. For Gable Gap (Figure 46), seismic velocities of the unsaturated Hanford units exhibit a broader range, but the Hanford velocity contrasts are also relatively low and should yield weak reflections. 


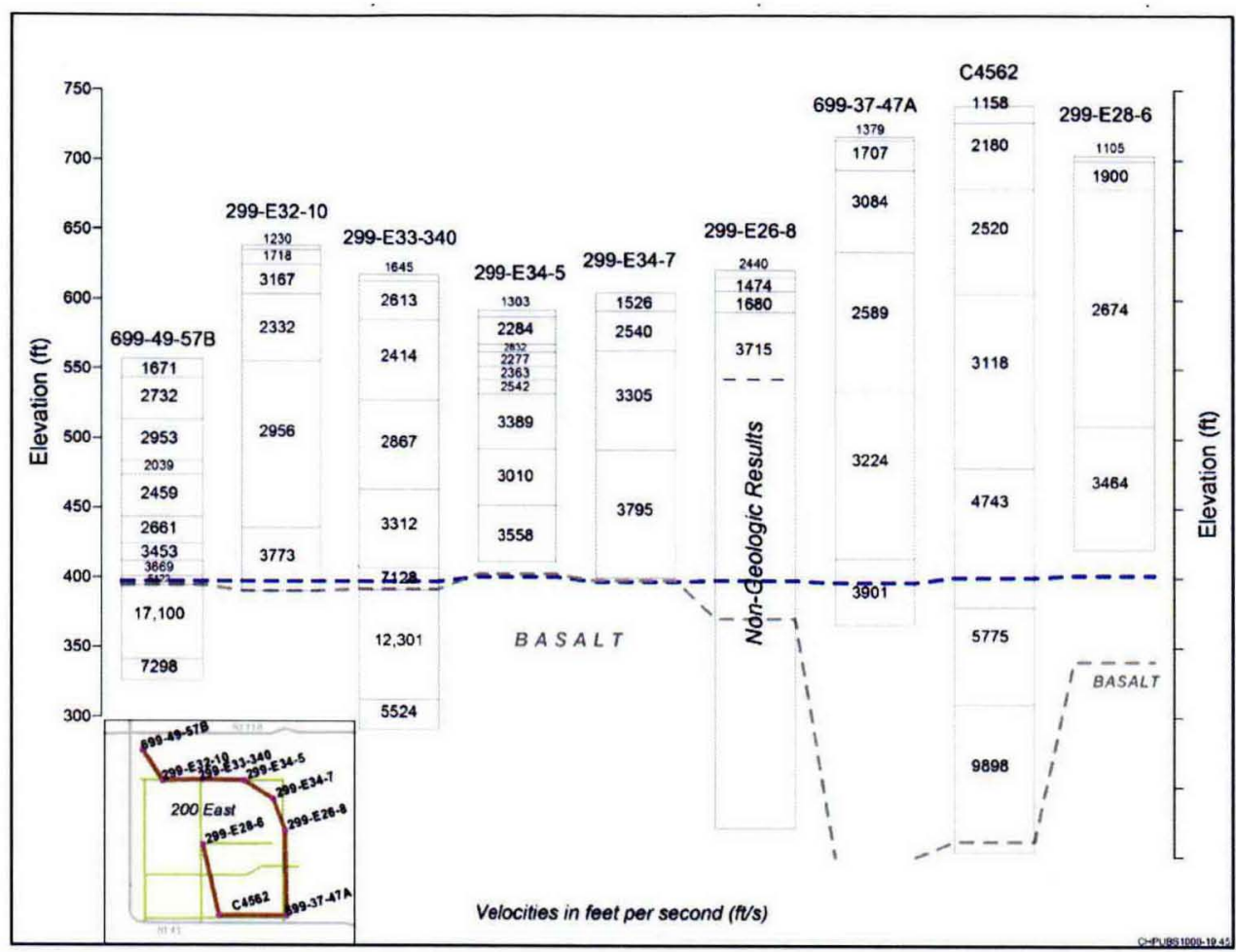

Figure 45. 200 East: Compressional-Wave Velocities

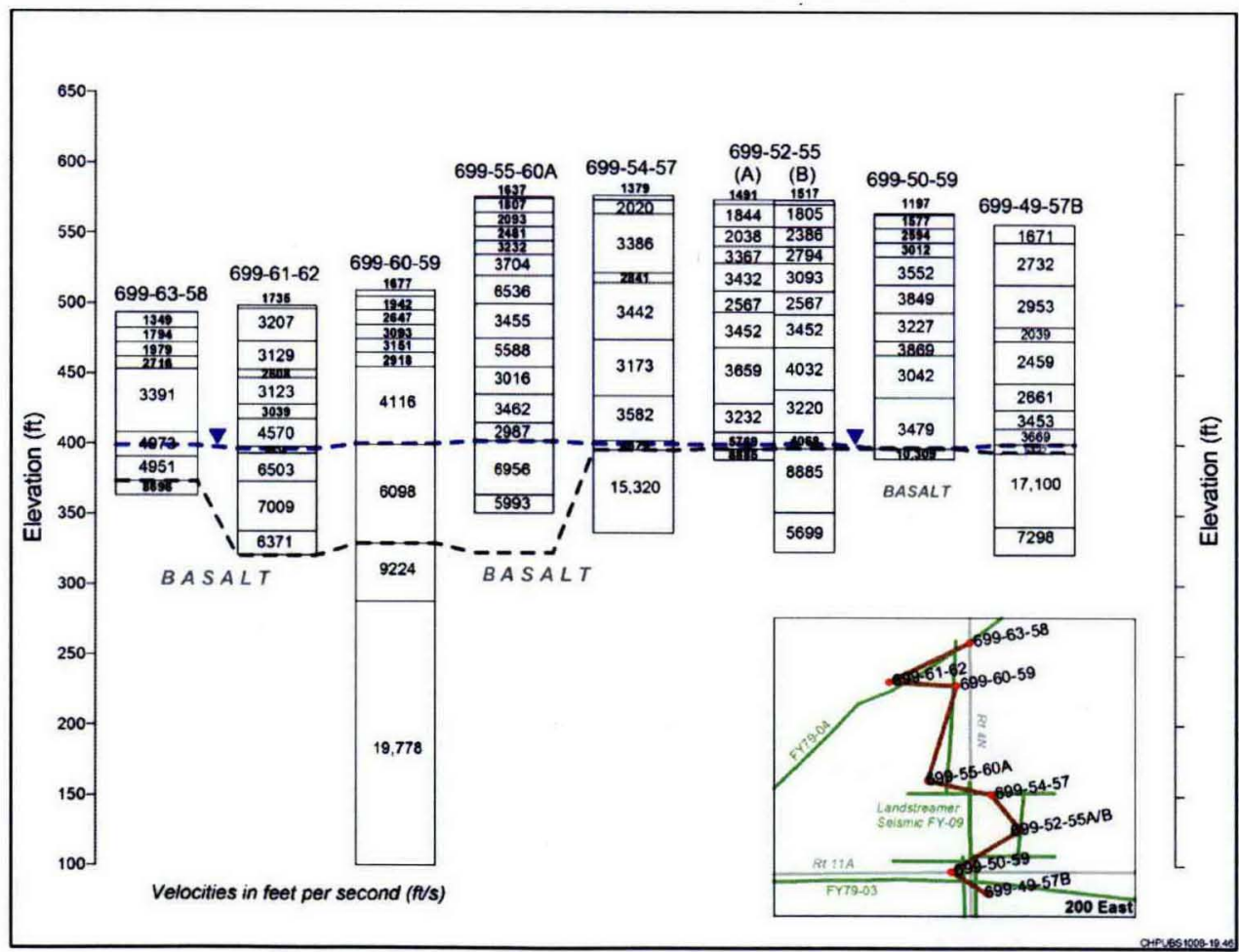

Figure 46. Gable Gap: Compressional-Wave Velocities 


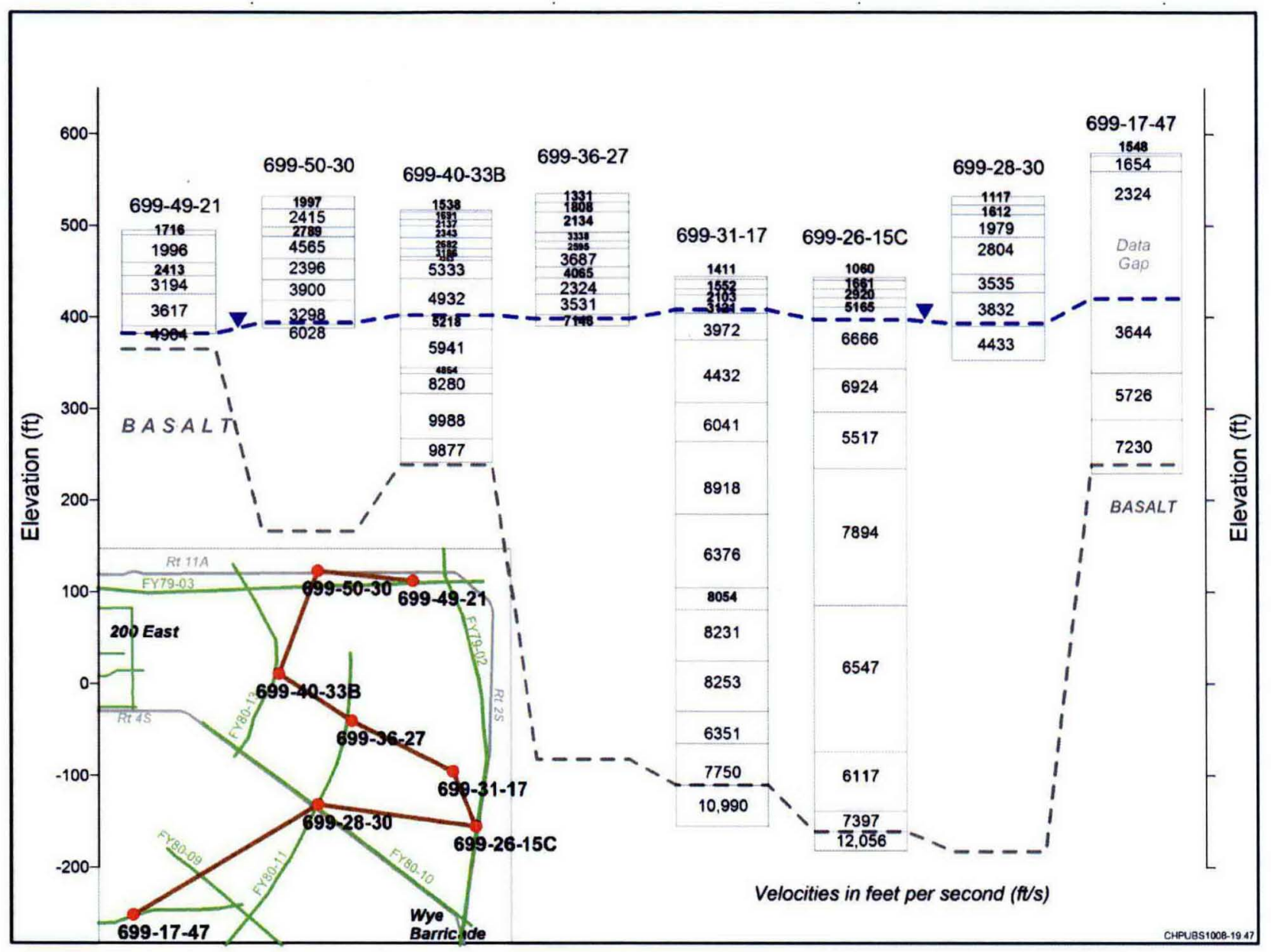

Figure 47. Cold Creek Basin: Compressional-Wave Velocities

The cross-section through the Cold Creek Basin (Figure 47) samples a larger amount of the saturated supra-basalt sedimentary section. The unsaturated-saturated interface is generally $457.2 \mathrm{~m} / \mathrm{s}$ to $609.6 \mathrm{~m} / \mathrm{s}$ $(1,500 \mathrm{ft} / \mathrm{s}$ to $2,000 \mathrm{ft} / \mathrm{s})$, and velocity contrasts intra-saturated sediment velocity contrasts can be upwards of $609.6 \mathrm{~m} / \mathrm{s}(2,000 \mathrm{ft} / \mathrm{s})$, which should yield strong intra-Ringold and Hanford/Cold Creek-Ringold reflections.

\section{Recommendations}

Check shot data should be used to help reprocess seismic reflection data collected in FY 2008 and FY 2009. The FY 2008 data did not have sufficient velocity information regarding Hanford units and focused on resolving top-of-basalt. A first pass at creating a depth section for the FY 2009 data yielded overestimates of depth to basalt in structural or erosional lows. This was primarily caused by the use of incorrect velocity functions.

A more powerful energy source for future check shot surveys in wells deeper than $79.3 \mathrm{~m}(260 \mathrm{ft})$ should be considered. Results from the FY 2009 surveys indicate that the ATV mounted accelerated weight drop provided sufficient energy to a depth of $182.9 \mathrm{~m}(600 \mathrm{ft})$ or more.

Future work will need to check the ROCSAN computer program and other data sets to allow further differentiation. 


\section{References}

ASTM D7400-08, 2008, Standard Test Methods for Downhole Seismic Testing, American Society for Testing and Materials, West Conshohocken, Pennsylvania.

Hanford Environmental Information System, Hanford Site database, Richland, Washington.

KGS, 1991, Seismic-Reflection Processing Demonstration Using Eavesdropper, Open-File Report 91-27, Kansas Geological Survey, Lawrence, Kansas.

Northland Geophysical, 2004, Results of Downhole Seismic Velocity Surveys, Department of Energy Office of River Protection Waste Treatment Plant, Hanford, Washington (letter report and data transmittal to Pacific Northwest National Laboratory), Northland Geophysical, PLLC, August 30 .

PNNL-16559, 2007, Downhole Measurements of Shear-and Compressional-Wave Velocities in Boreholes C4993, C4996, C4997 and C4998 at the Waste Treatment Plant DOE Hanford Site, Pacific Northwest National Laboratory, Richland, Washington.

PNNL-16652, 2007, Site-Specific Velocity and Density Model for the Waste Treatment Plant, Hanford Washington, Pacific Northwest National Laboratory, Richland, Washington. Available at: http://www.pnl.gov/main/publications/external/technical_reports/PNNL-16652.pdf.

Press, F., 1966, “Seismic Velocities,” Handbook of Physical Constants, Sydney P. Clark; ed., GSA Memoir 97, Geological Society of America, Boulder, Colorado, pp 195-218.

PSPL, 1982, Skagit/Hanford Nuclear Project, Preliminary Safety Analysis Report, Volumes 2 through 7 , Puget Sound Power and Light Company, Bellevue, Washington.

Rimrock Geophysics, 1992, SIPT2 Refraction Processing Software, Version 3.2, Rimrock Geophysics, Inc., Boulder, Colorado.

SGW-39020, 2008, Test Plan: Check Shot Surveying in the 200E Area, Fluor Hanford, Inc., Richland, Washington.

SGW-39675, 2009, Reflection Seismic Survey Report, 200 East Area, Hanford Site, Rev 0, CH2M HILL Plateau Remediation Company, Richland, Washington. Available at: http://www5.hanford.gov/arpir/?content=findpage \&AKey=0084392.

SGW-43746, 2009, Landstreamer/Gimbaled GeoPhone Acquisition of High Resolution Seismic Reflection Data North of the 200 Areas - Handford Site, Rev. 0, CH2M HILL Plateau Remediation Company, Richland, Washington.

SSC, 1979, Final Report on a Seismic Reflection Survey Conducted in Benton and Grant Counties, Washington, FY-79 Program, Pasco Basin, Hanford Site, Basalt Waste Isolation Program, Seismograph Service Corporation, Tulsa, Oklahoma.

SSC, 1980, Final Report on a Seismic Reflection Survey Conducted in Benton County, Washington, FY-80 Program, Pasco Basin, Hanford Site, Basalt Waste Isolation Program, Seismograph Service Corporation, Tulsa, Oklahoma. 
Waddell, M.G., W.J. Domoracki, T.J. Temples, and J. Eyer, 1999, Non-Invasive Determination of the Location and Distribution of Free-Phase Dense Nonaqueous Phase Liquids (DNAPL) by Seismic Reflection Methods, Interim Report for Tasks 1, 2, and 3, Earth Sciences and Resources Institute, University of South Carolina, Columbia, South Carolina. 
SGW-47535, REV. 0

1 
SGW-47535, REV. 0

Appendix A

Filtered and Unfiltered Plots of Raw Check Shot Records 
SGW-47535, REV. 0 


\section{A Filtered and Unfiltered Plots of Raw Check Shot Records}

Raw and filtered check shot records for the wells surveyed in September 2008, June 2009, and March and April 2010 are shown in this appendix as Figure A1 through Figure A29. The data are displayed by trace number and travel time, with depth increasing from top-to-bottom of each plot. A heavy blue trace line is used to denote where the start of the seismic signal is interpreted, and light-blue colored dots or red hatch marks indicate the travel time pick. 


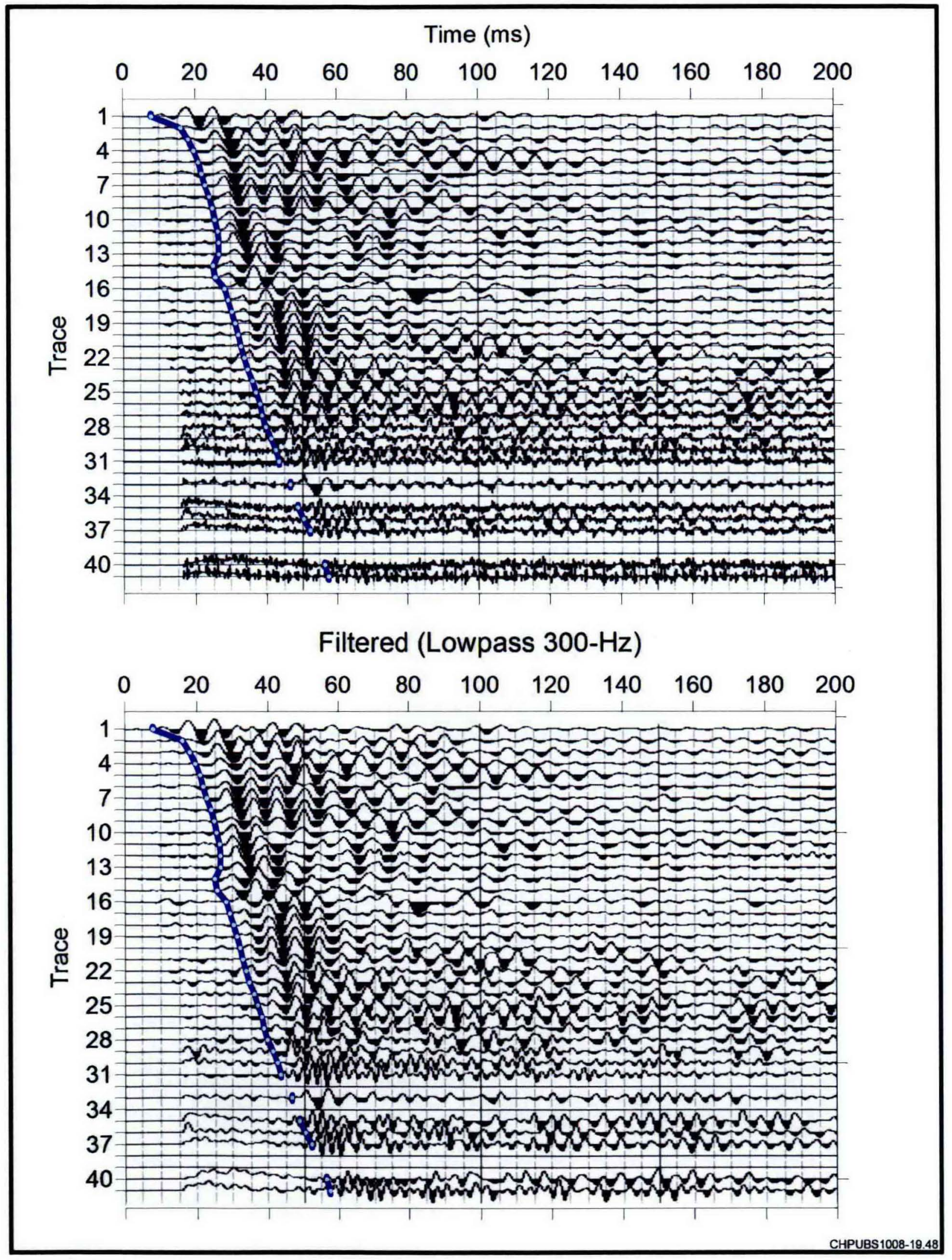

Figure A1. Check Shot: Well 299-E28-06 


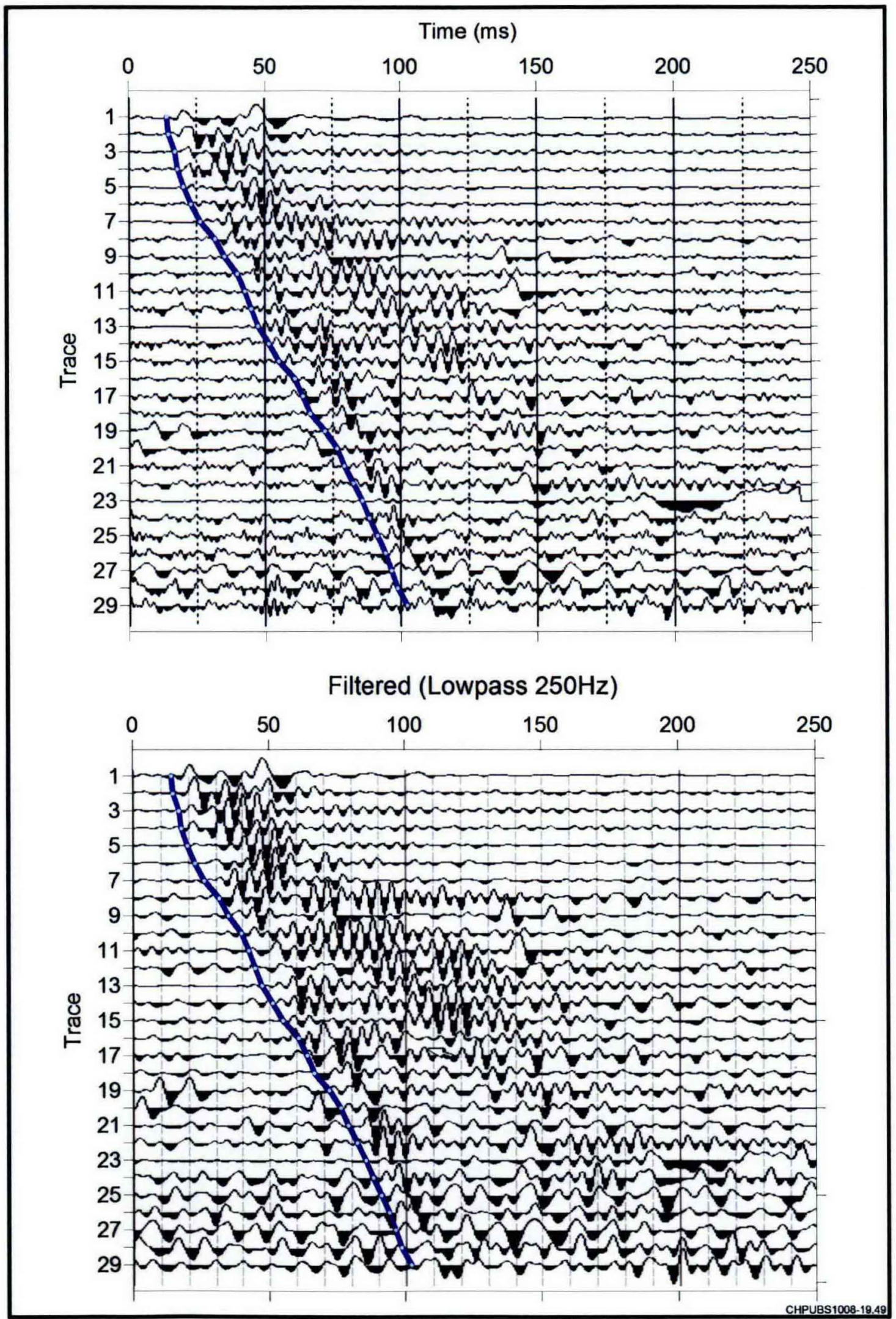

Figure A2. Check Shot: Well 299-E28-06 


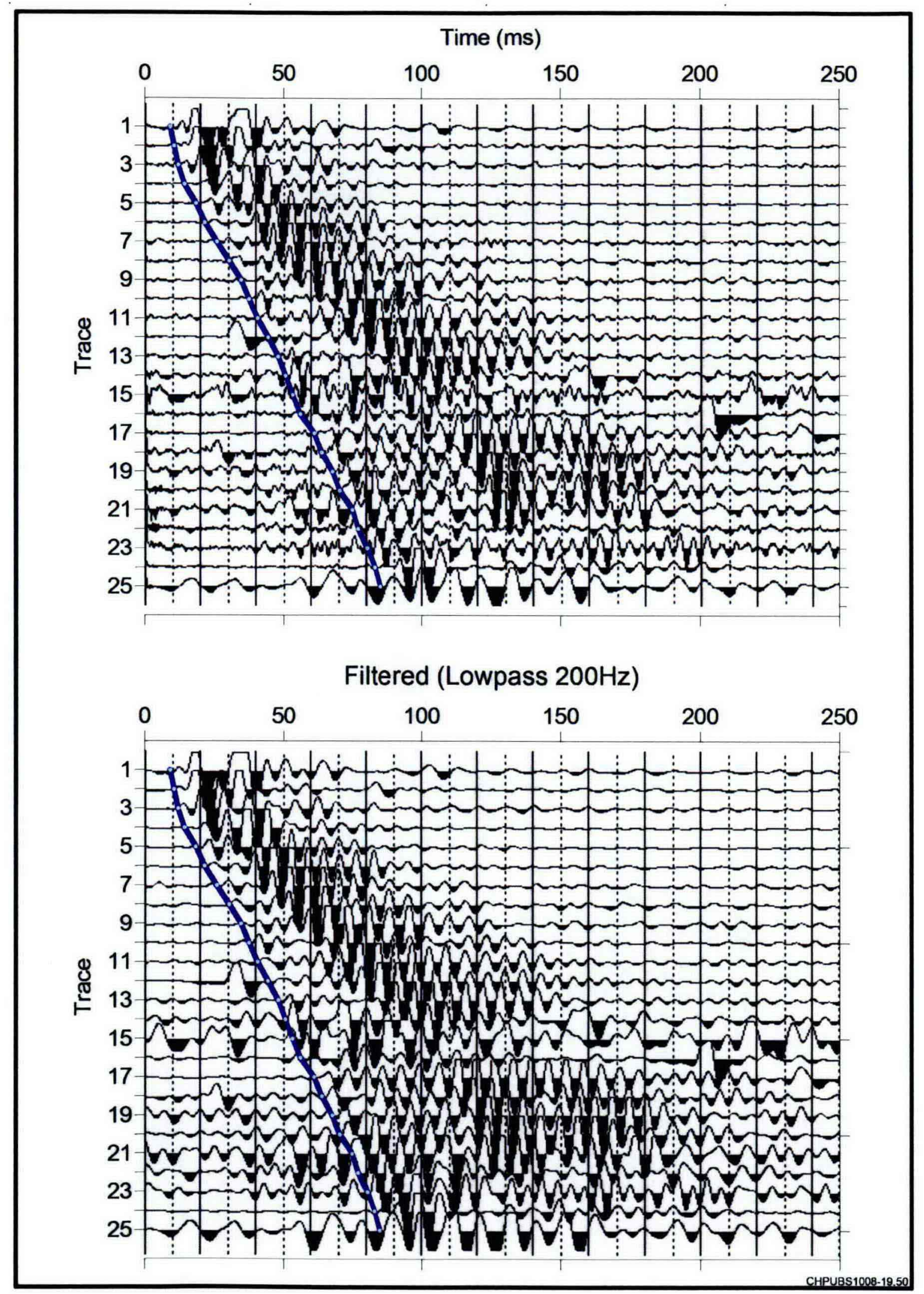

Figure A3. Check Shot: Well 299-E32-10 


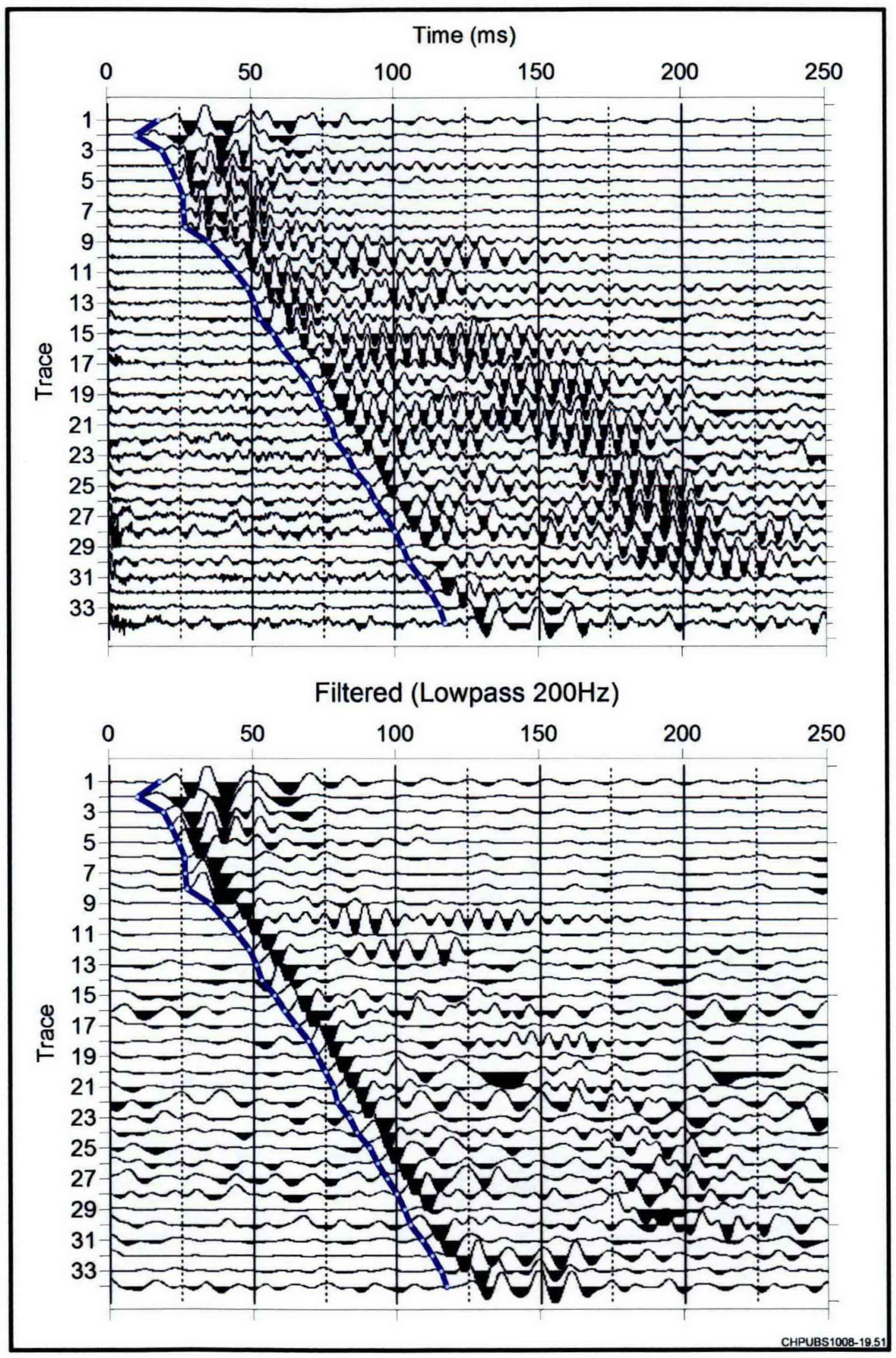

Figure A5. Check Shot: Well 699-37-47A 


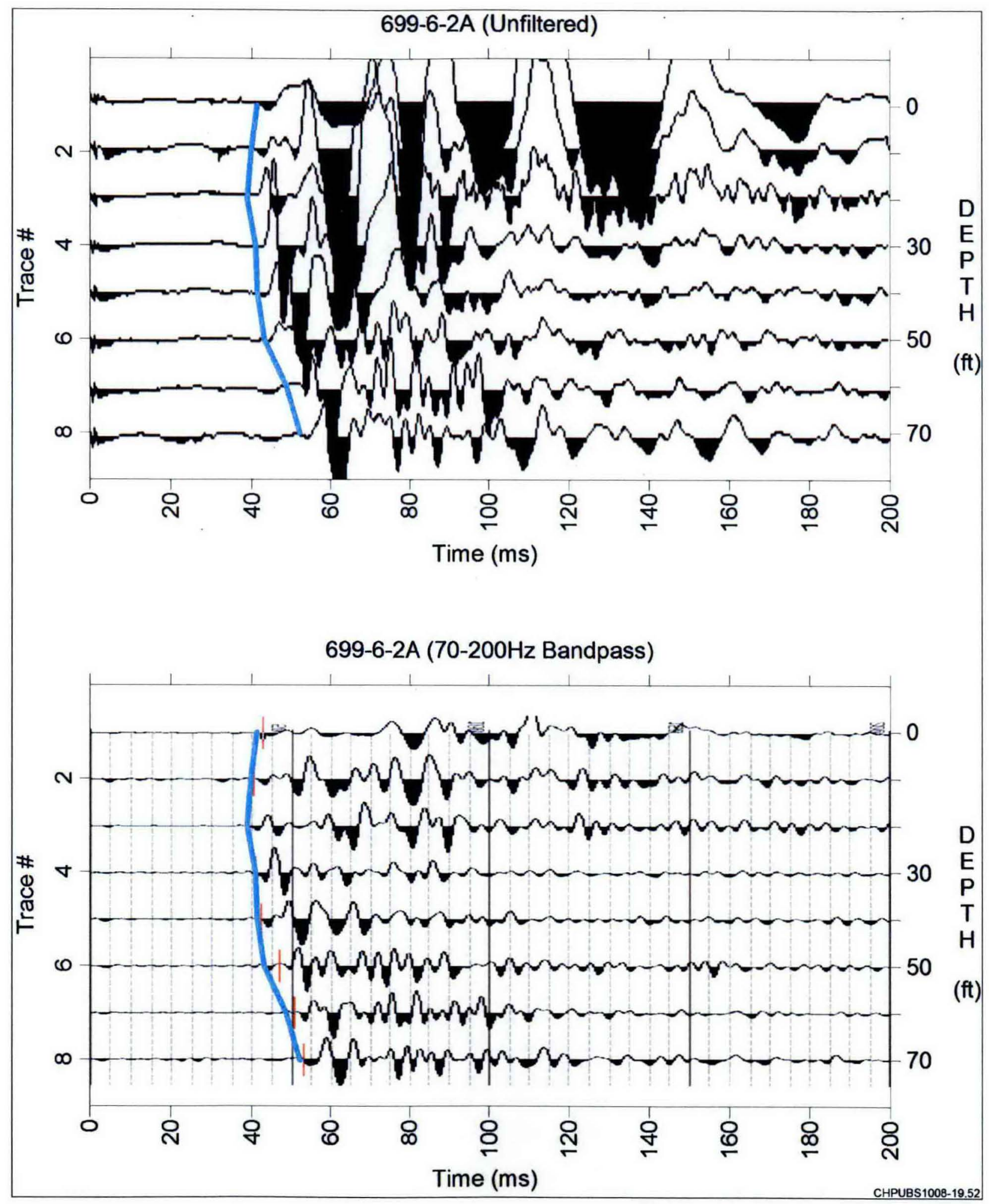

Figure A6. Check Shot: Well 699-6-2A 


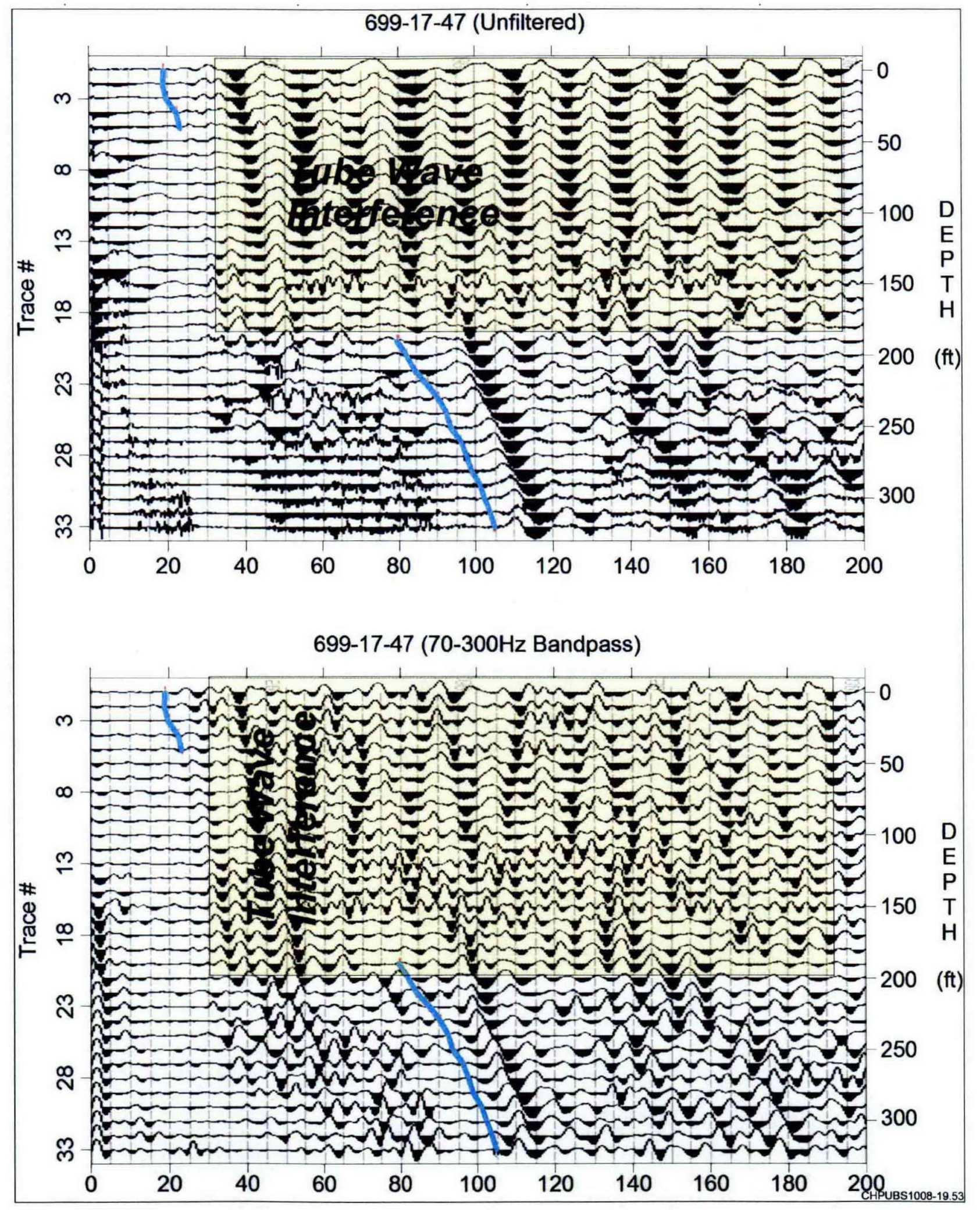

Figure A7. Check Shot: Well 699-17-47 


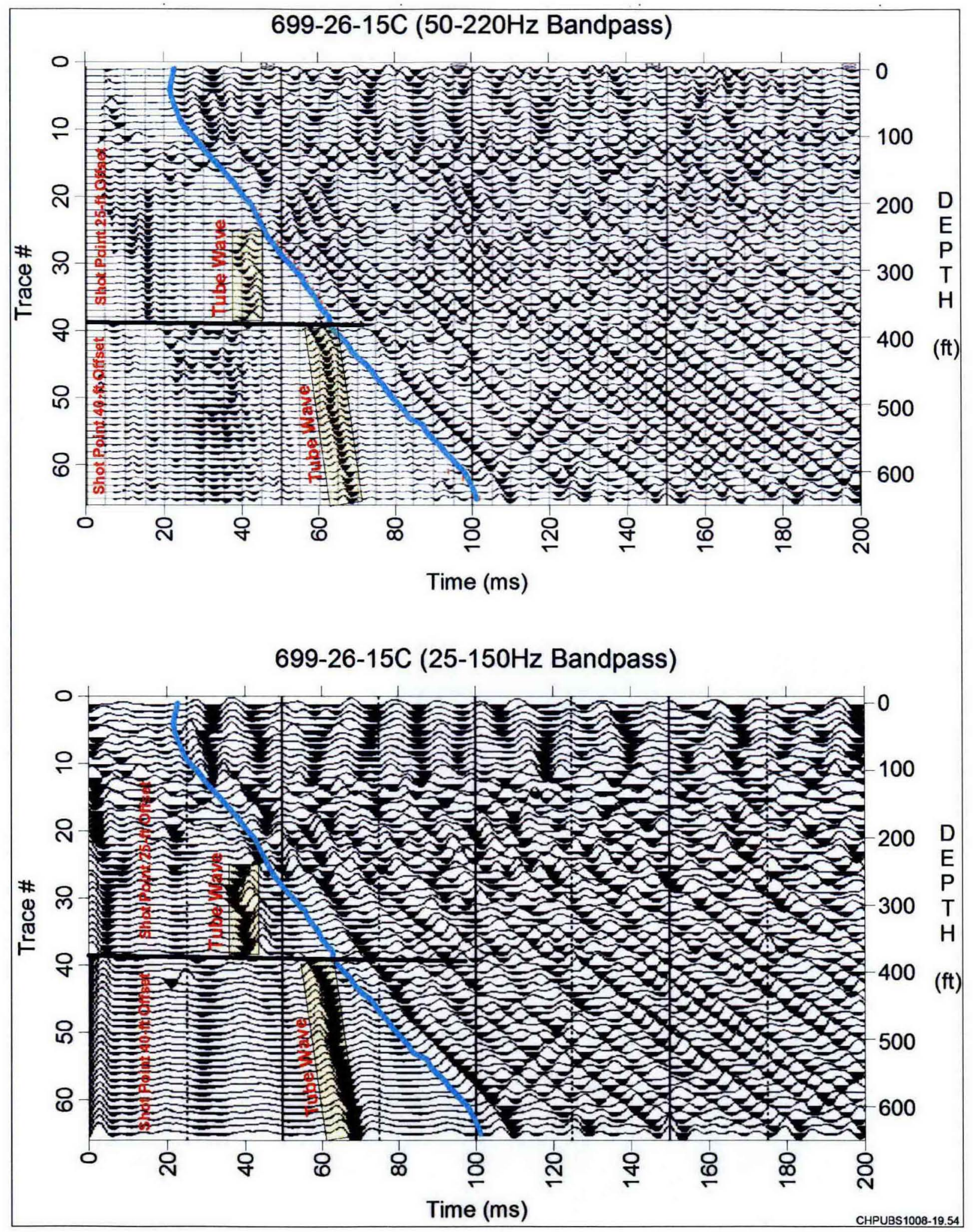

Figure A8. Check Shot: Well 699-26-15C 


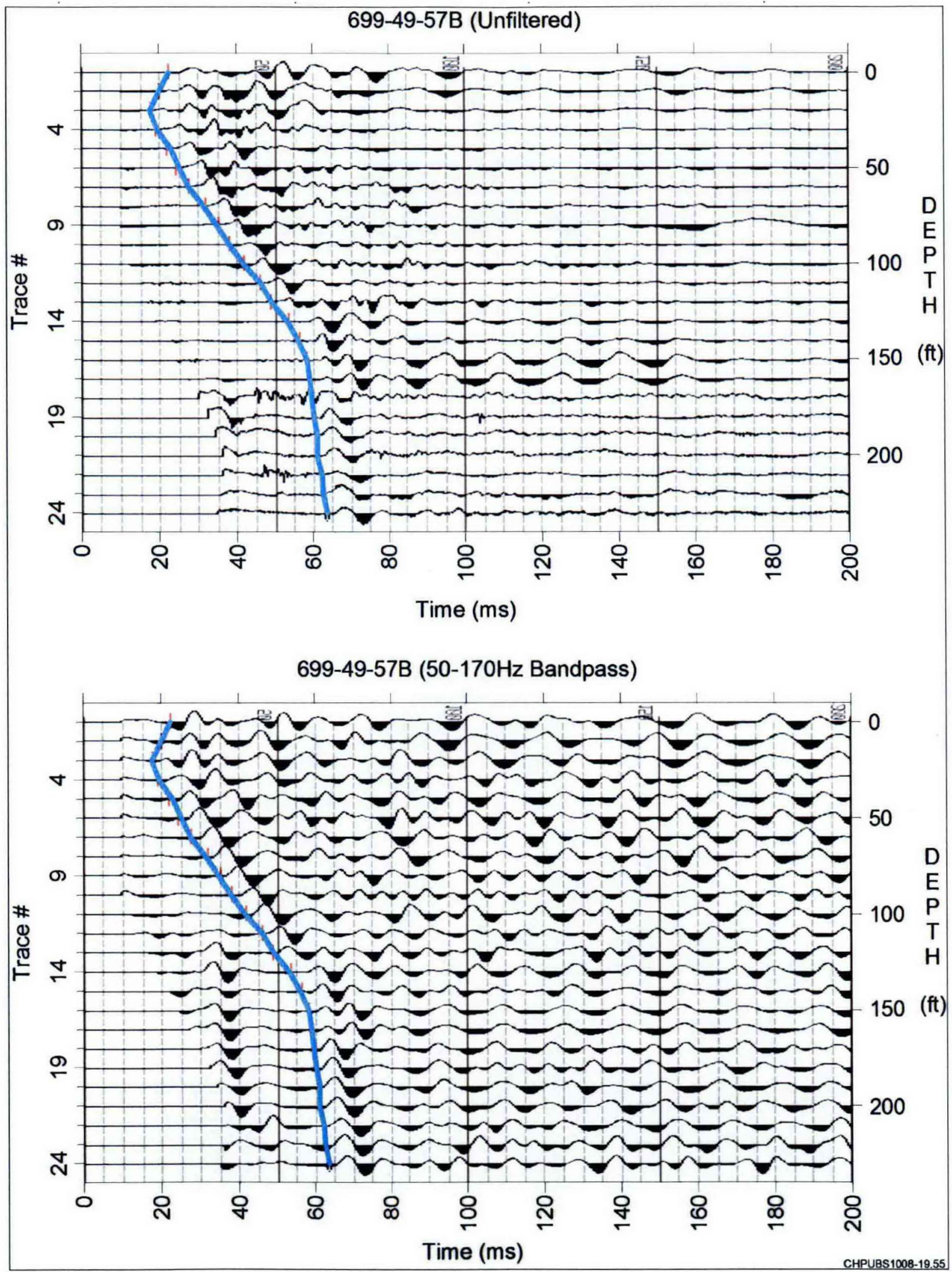

Figure A9. Check Shot: Well 699-49-57B 


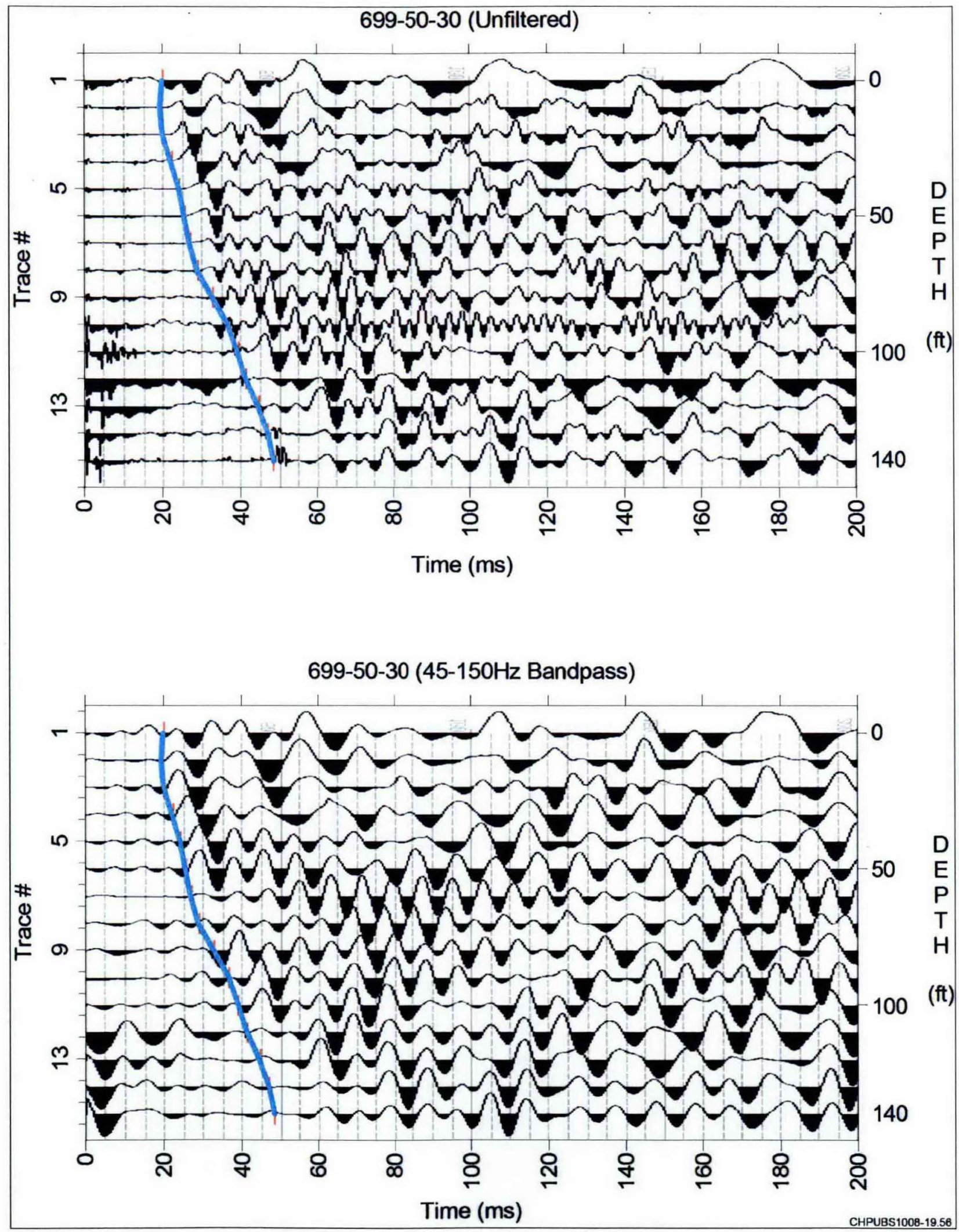

Figure A10. Check Shot: Well 699-50-30 


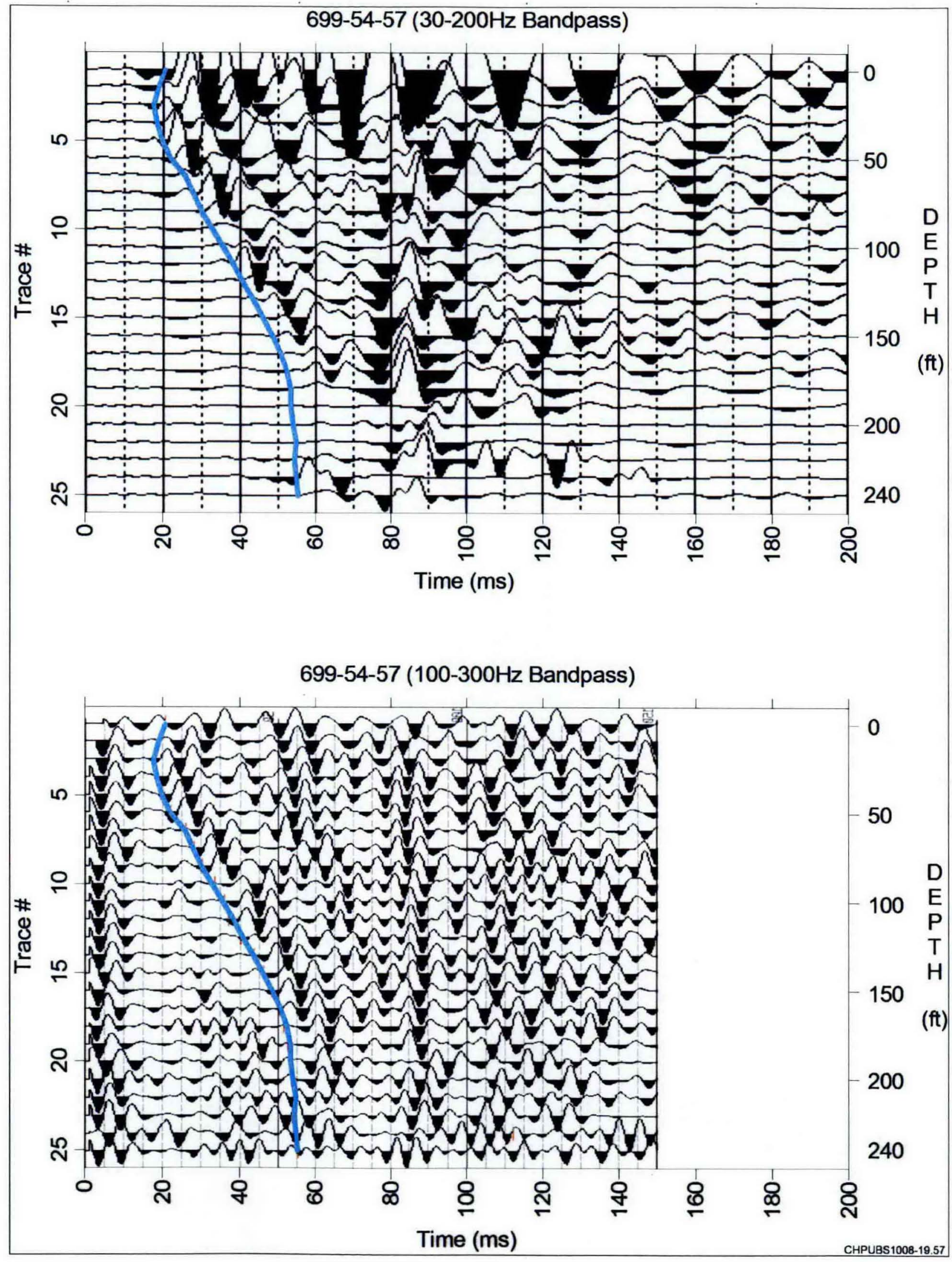

Figure A11. Check Shot: Well 699-54-57 


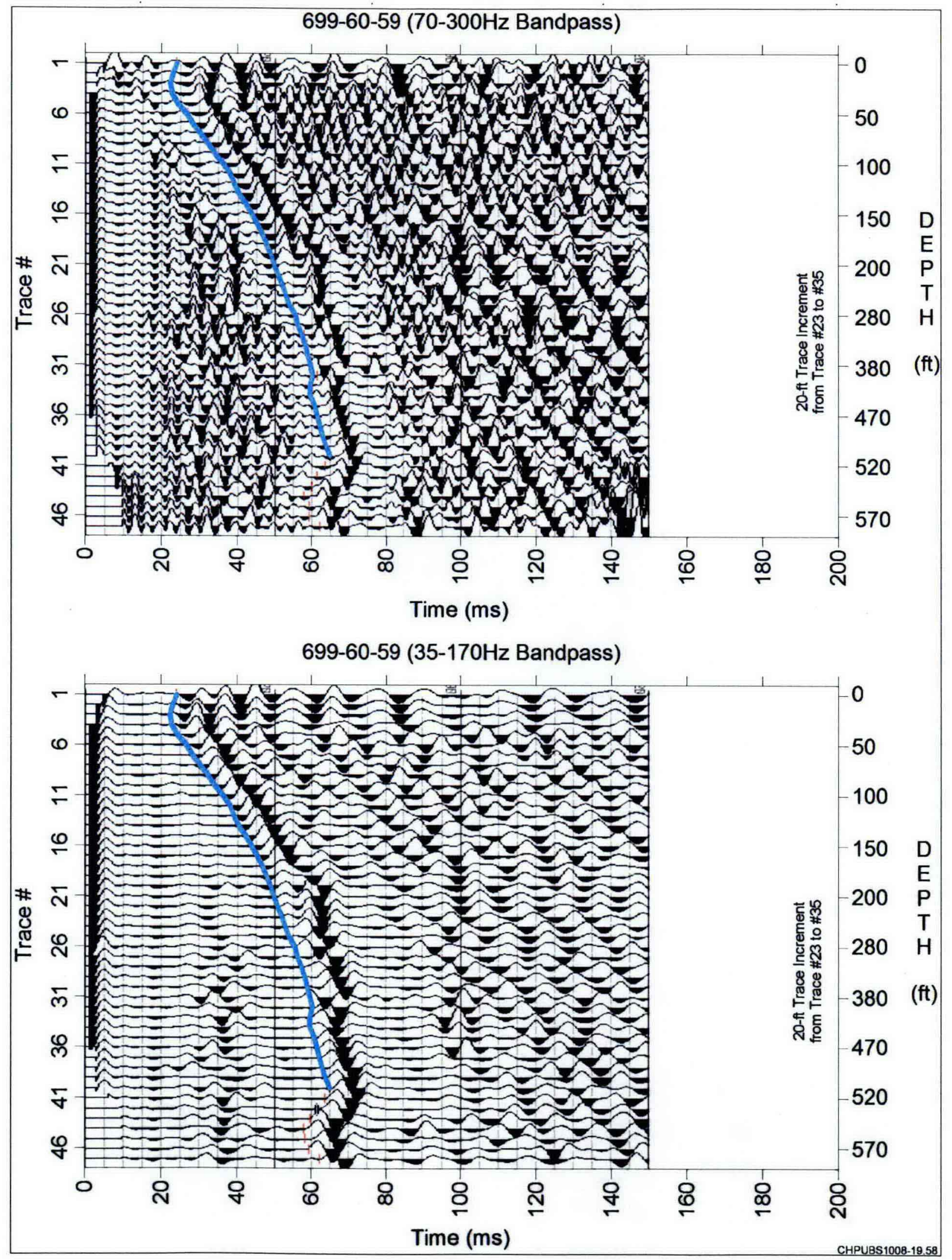

Figure A12. Check Shot: Well 699-60-59 


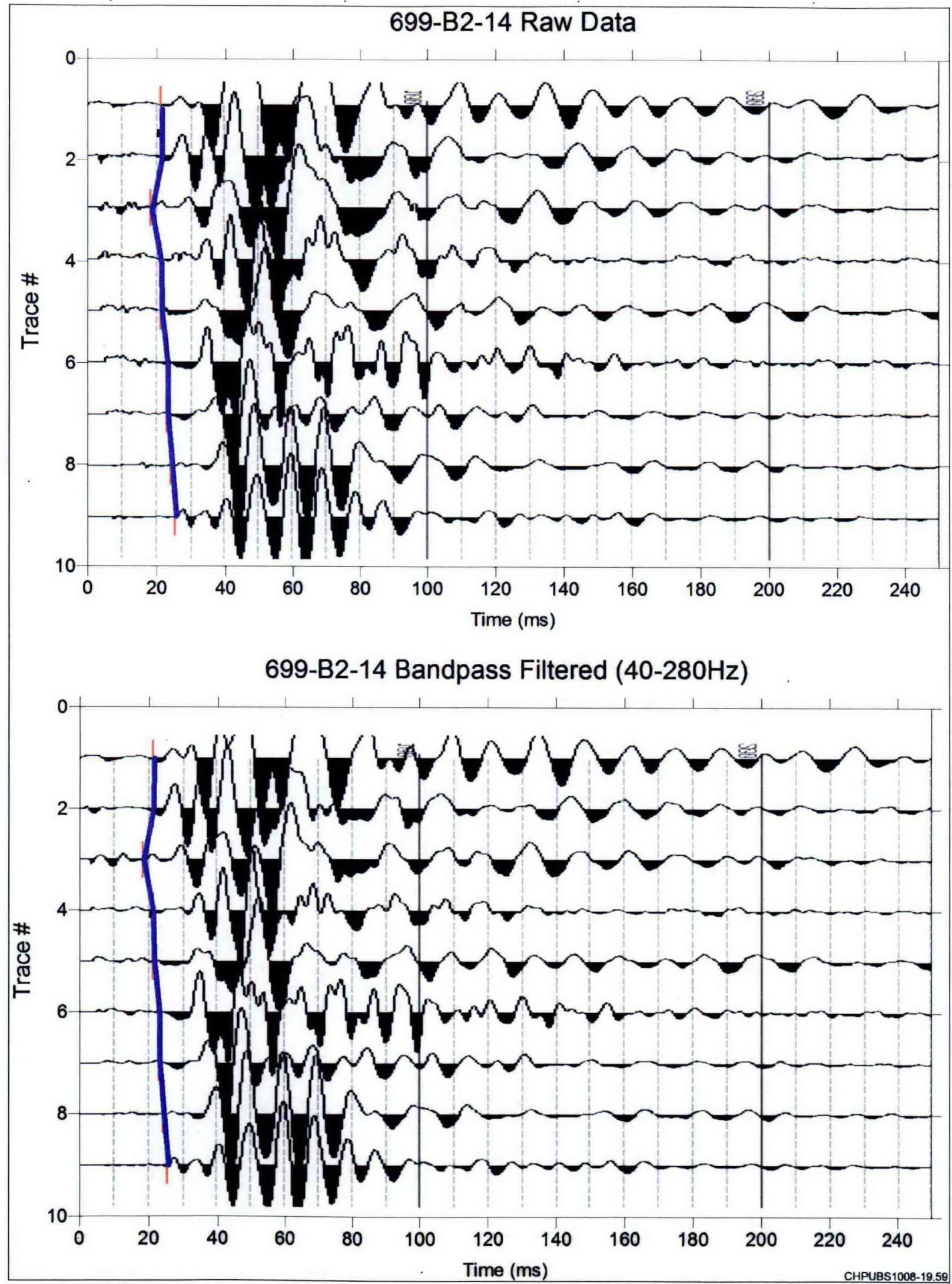

Figure A13. Check Shot: Well 699-B2-14 


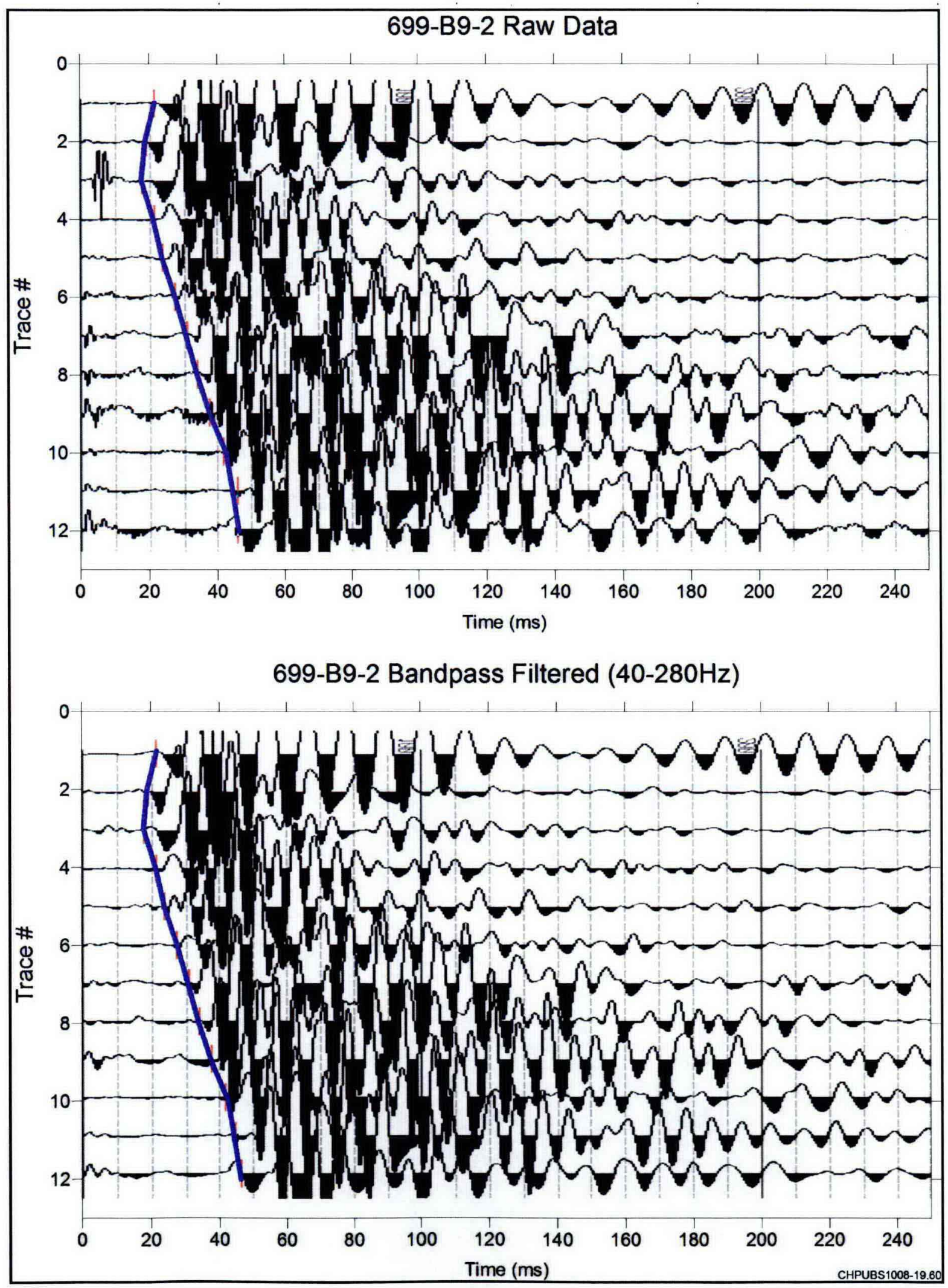

Figure A14. Check Shot: Well 699-B9-2 


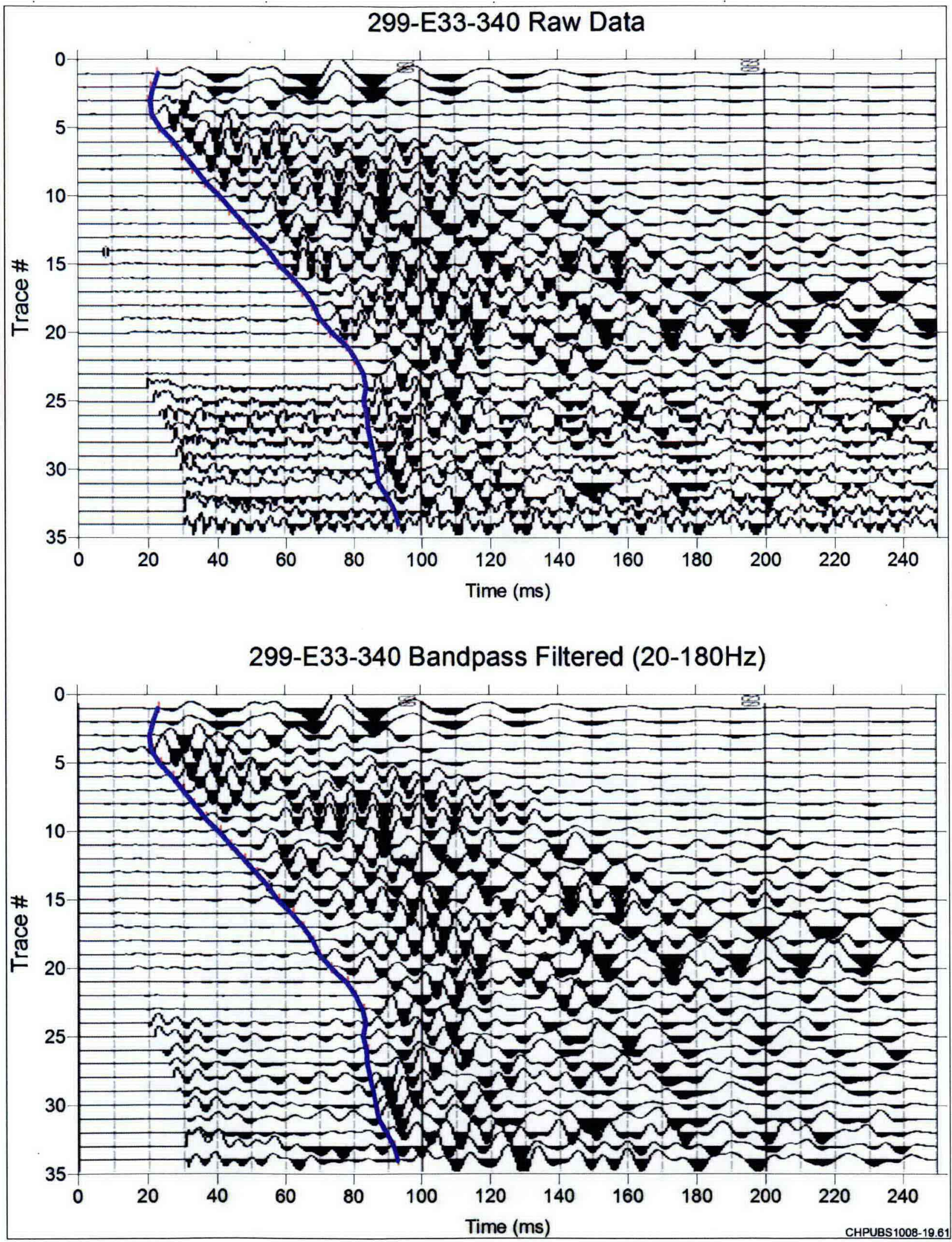

Figure A15. Check Shot: Well 299-E33-340 


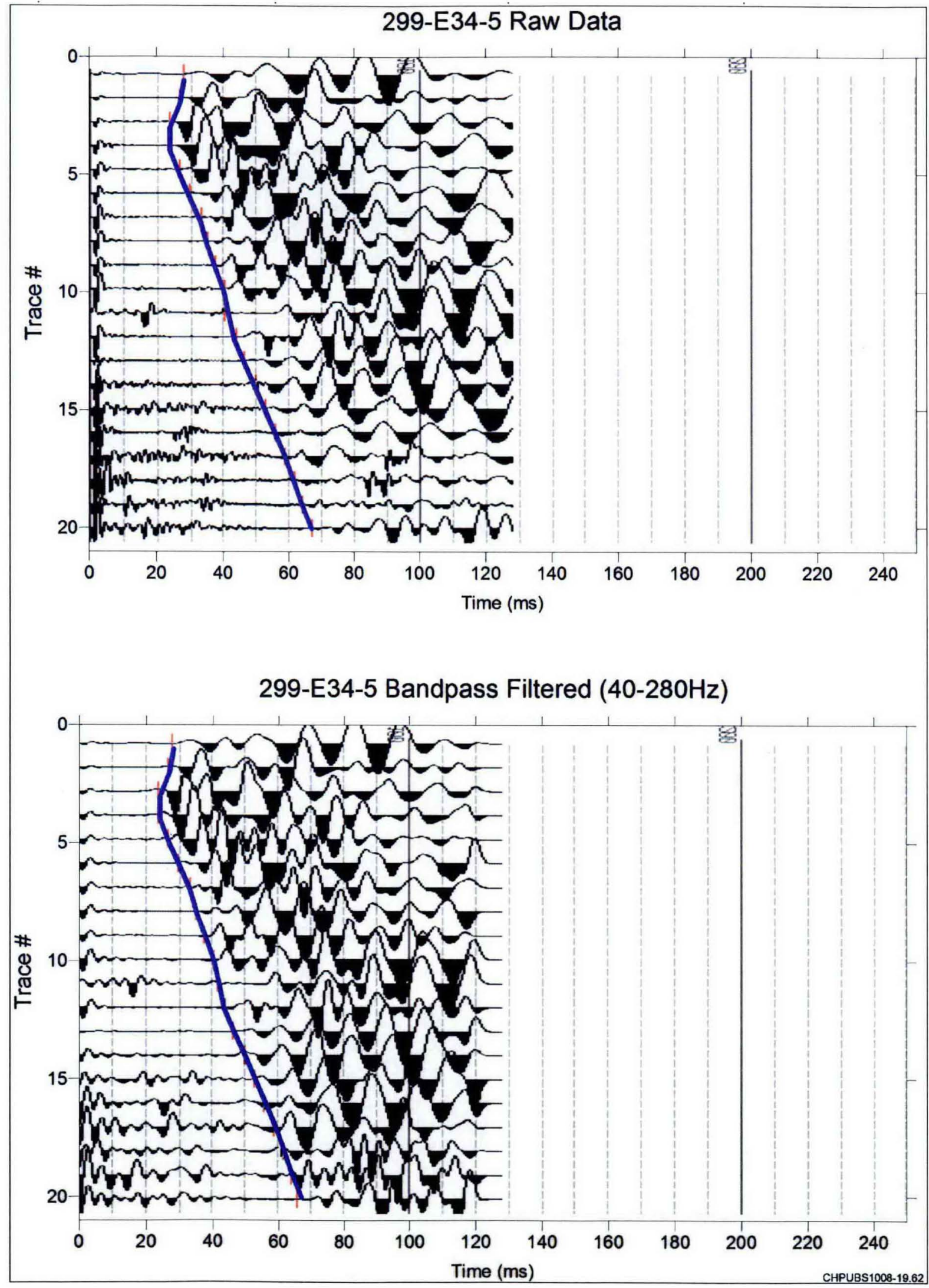

Figure A16. Check Shot: Well 299-E34-5 


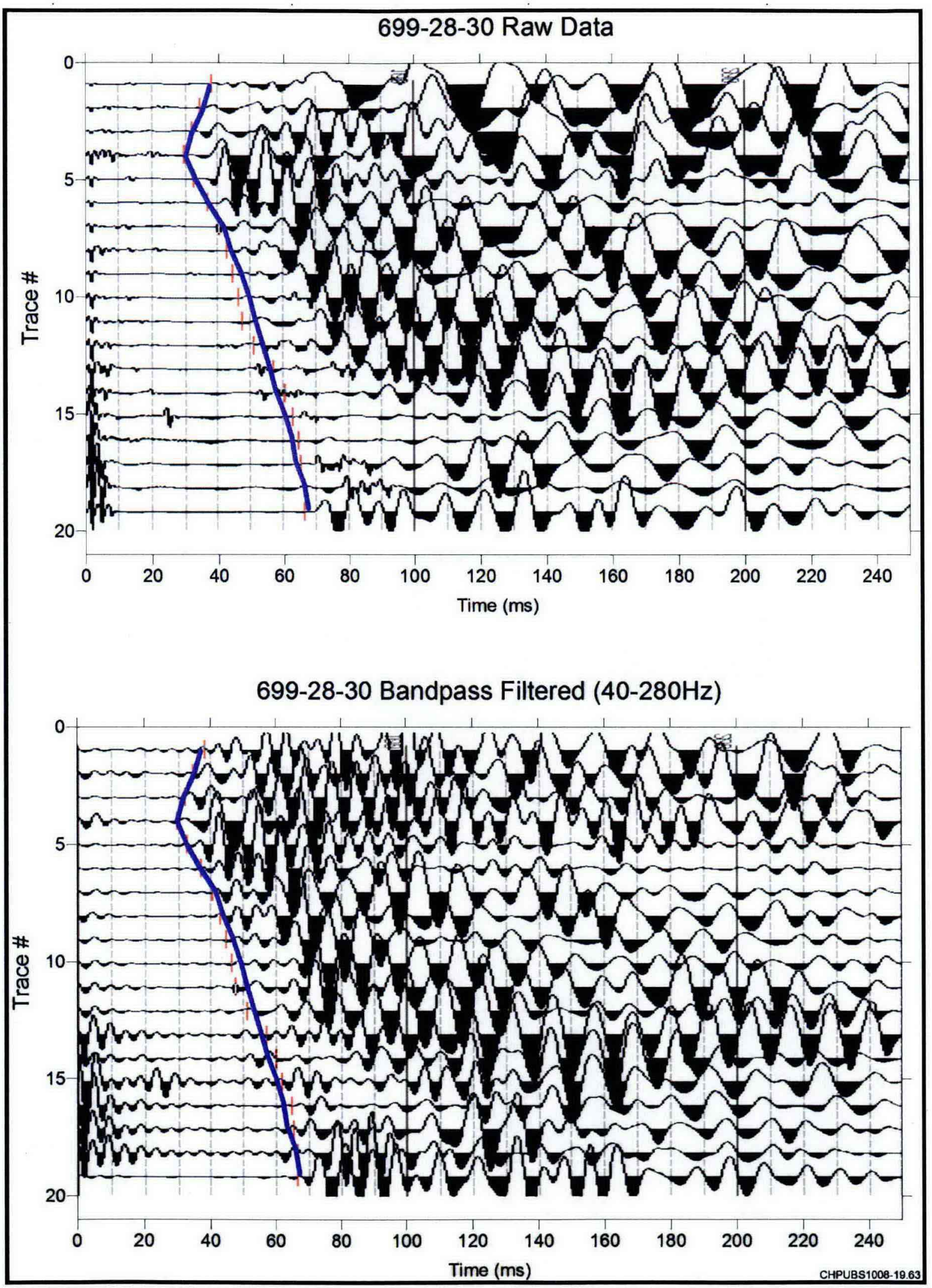

Figure A17. Check Shot: Well 699-28-30 


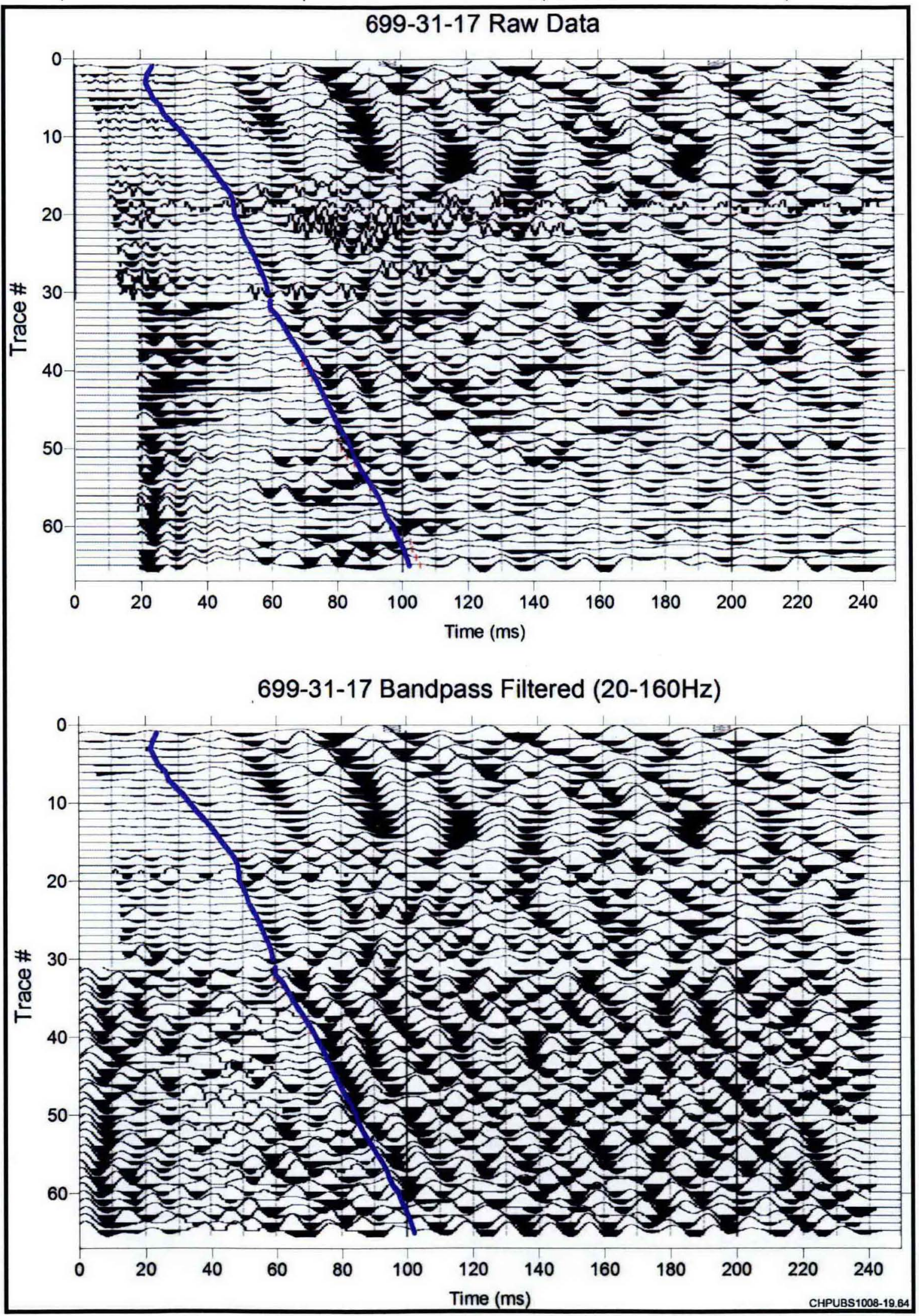

Figure A18. Check Shot: Well 699-31-17 


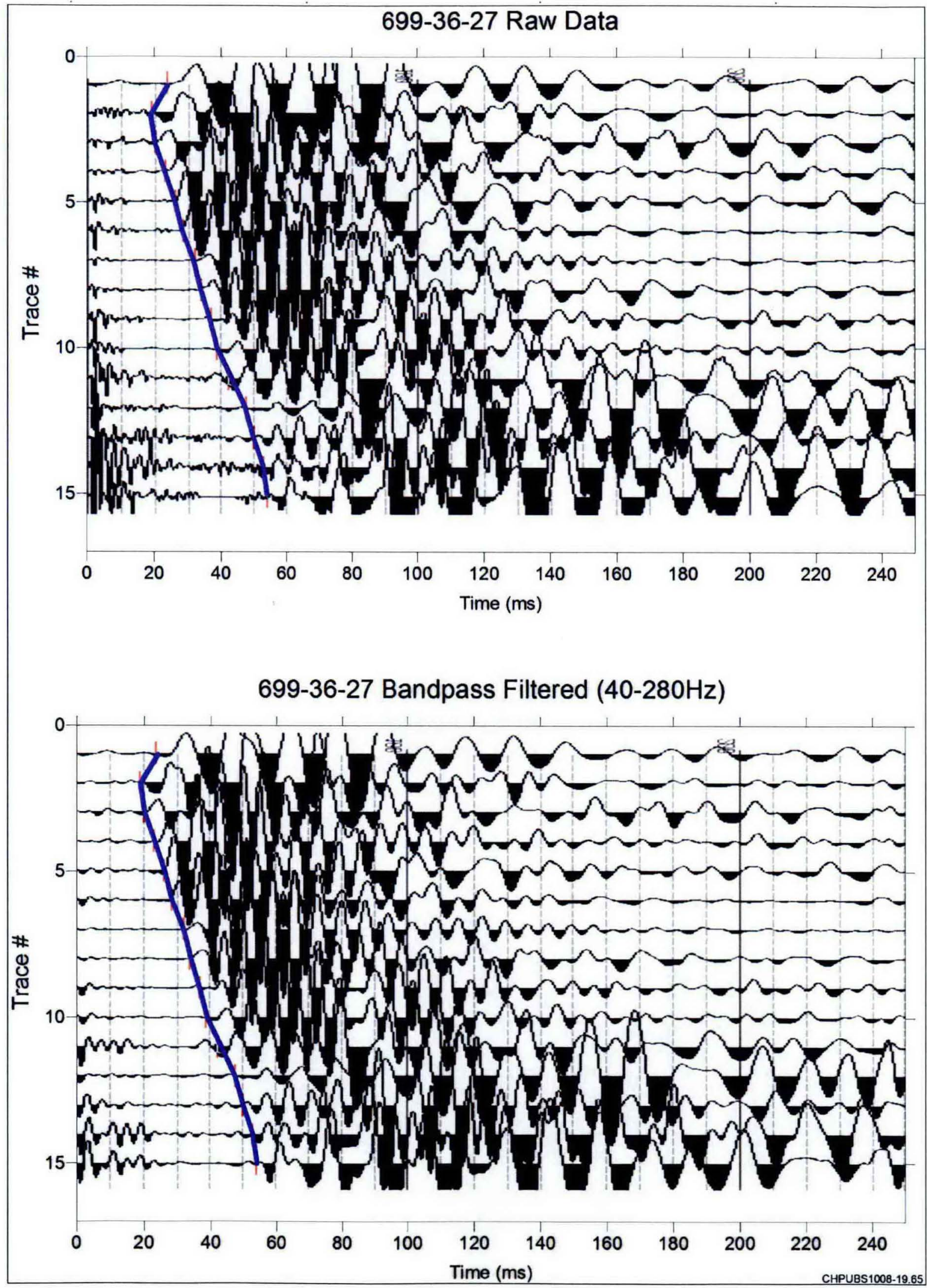

Figure A19. Check Shot: Well 699-36-27 


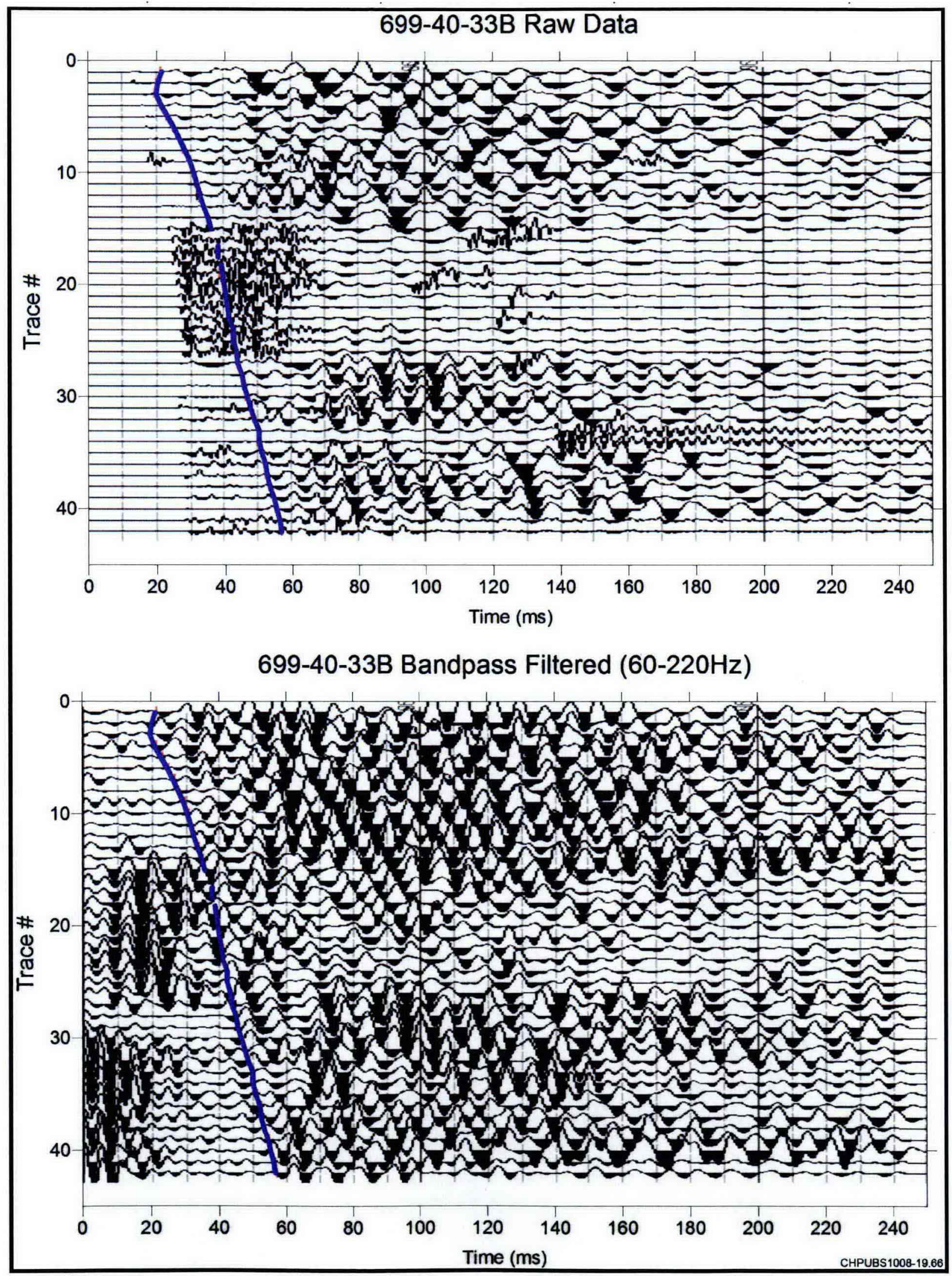

Figure A20. Check Shot: Well 699-40-33B 

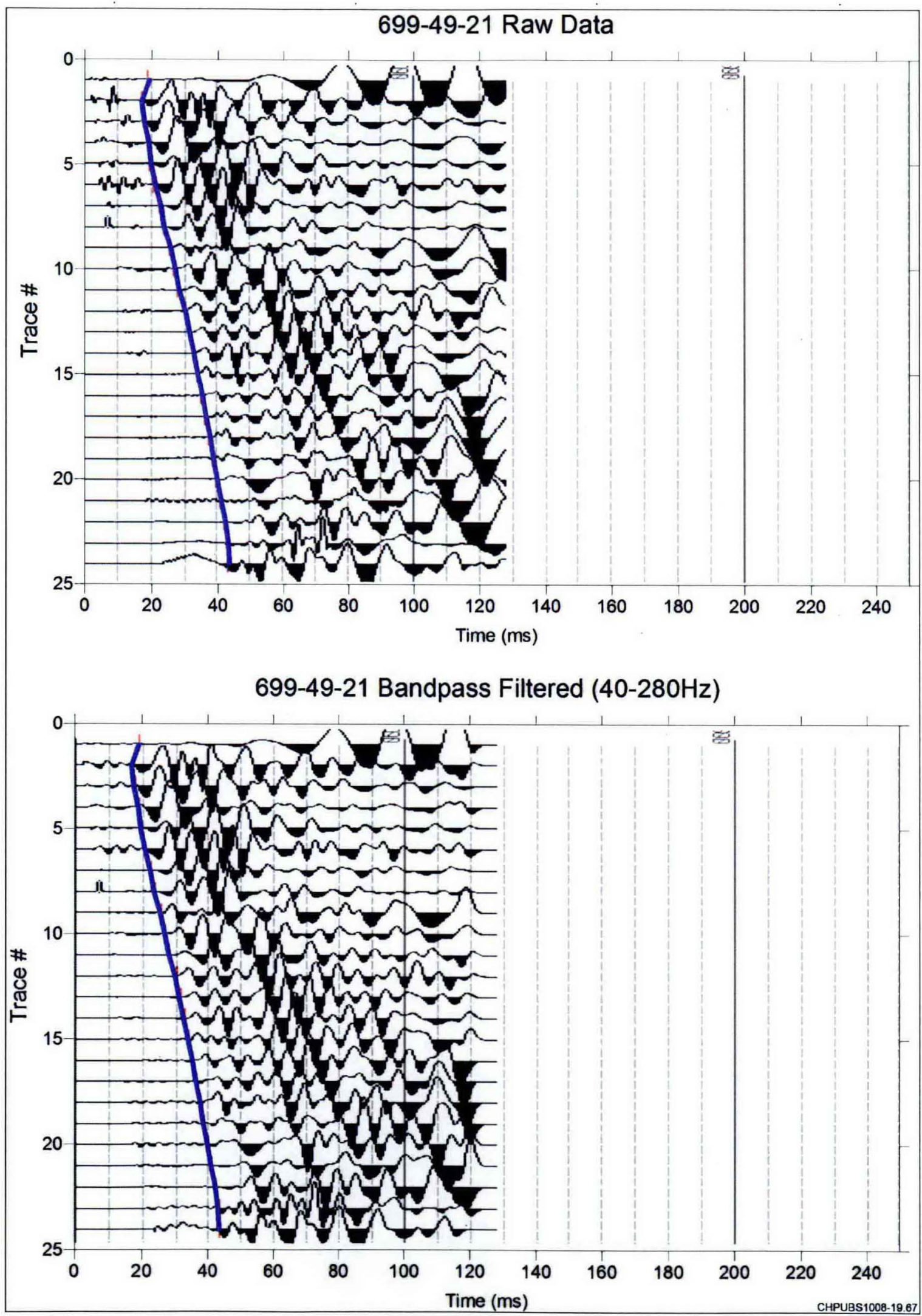

Figure A21. Check Shot: Well 699-49-21 


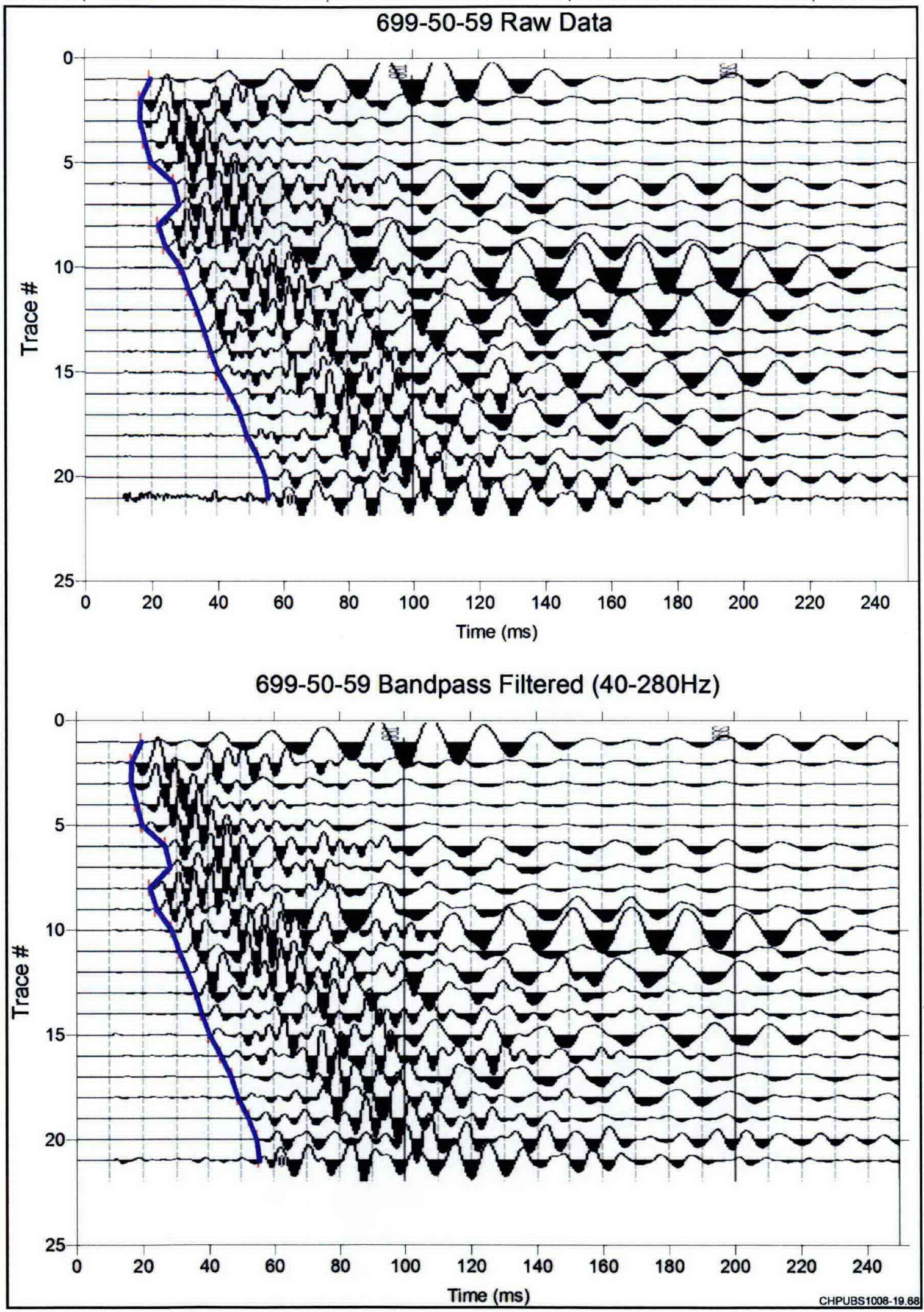

Figure A22. Check Shot: Well 699-50-59 


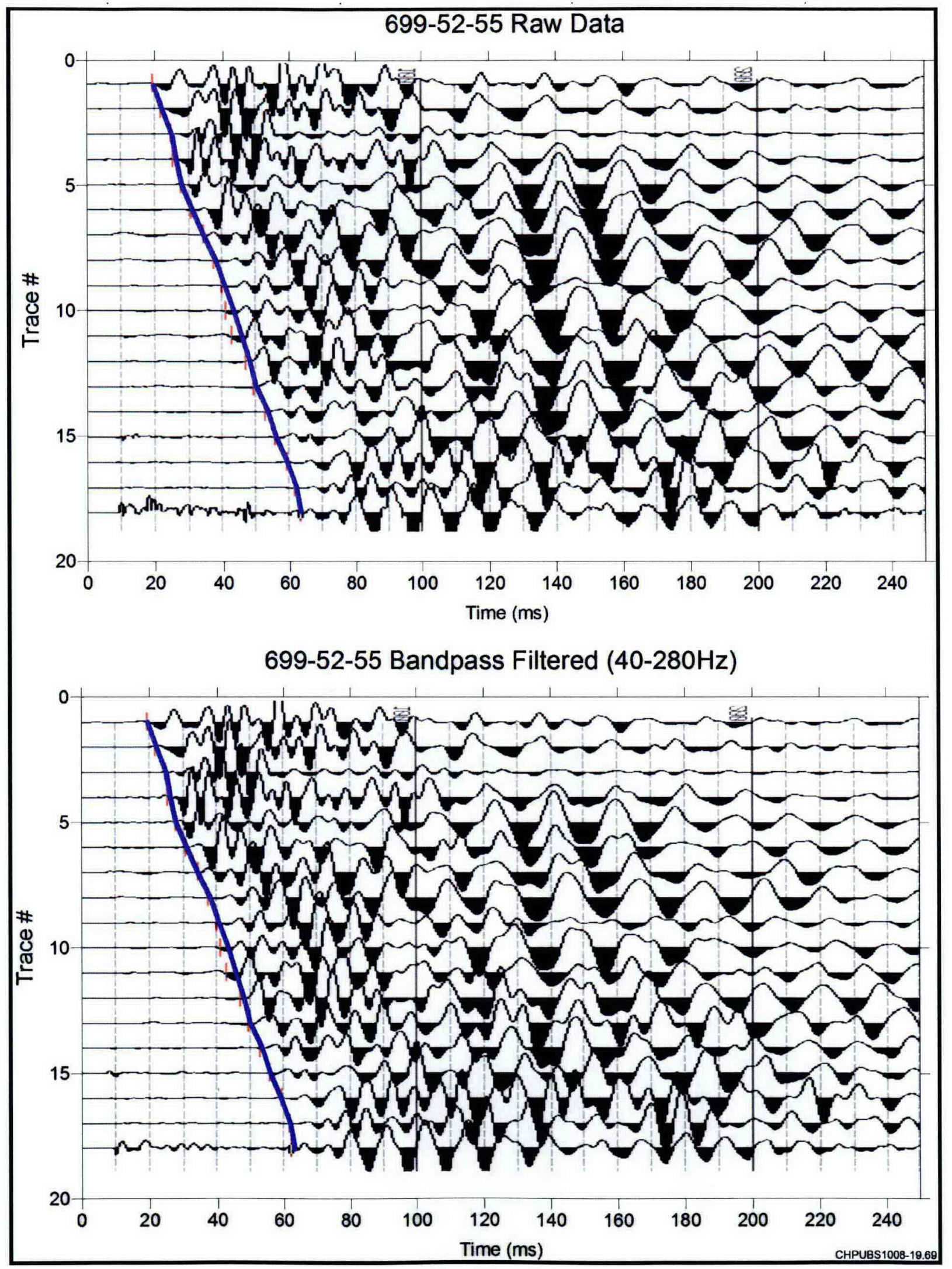

Figure A23. Check Shot: Well 699-52-55 


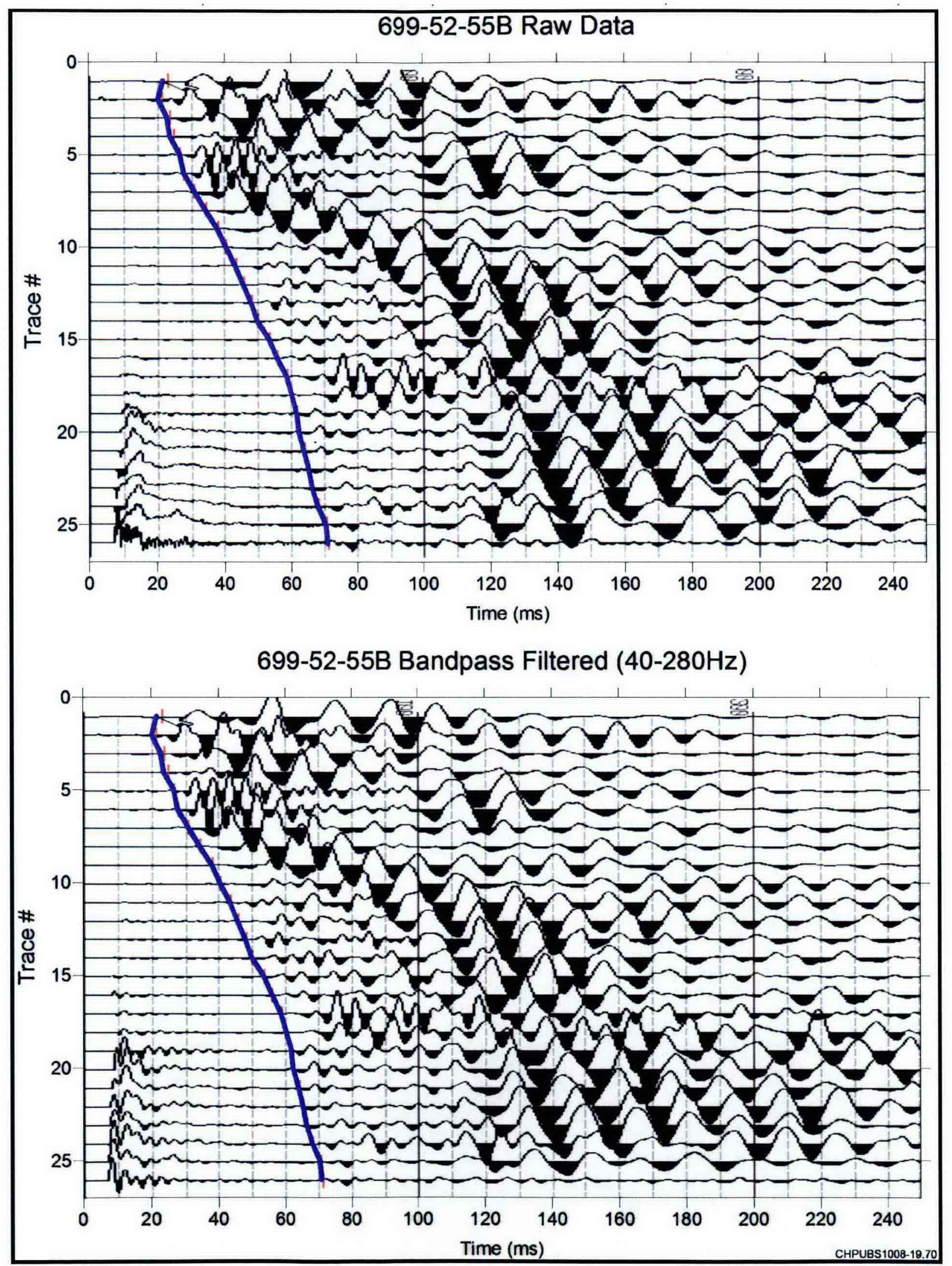

Figure A24. Check Shot: Well 699-52-55B 


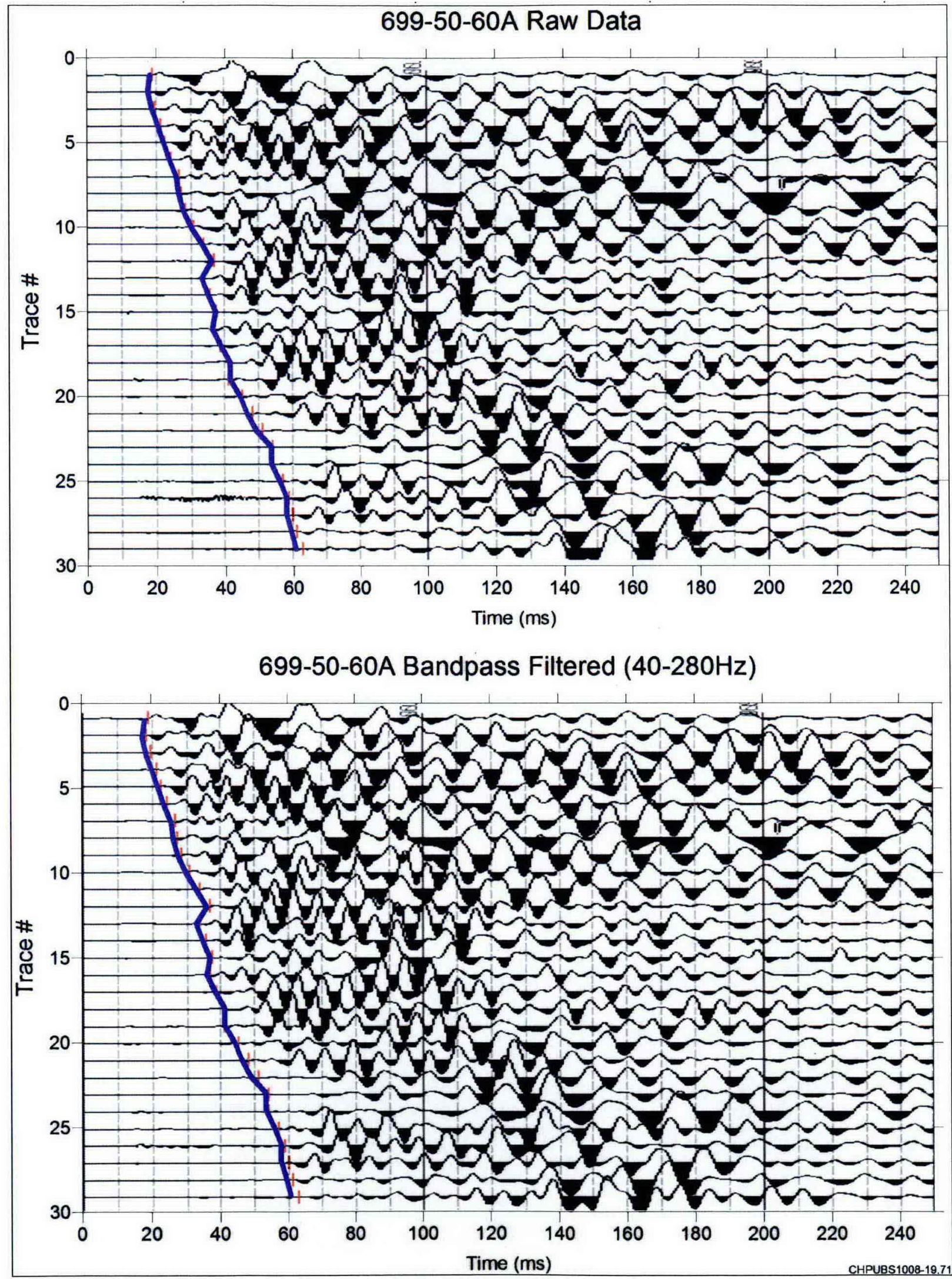

Figure A25. Check Shot: Well 699-50-60A 


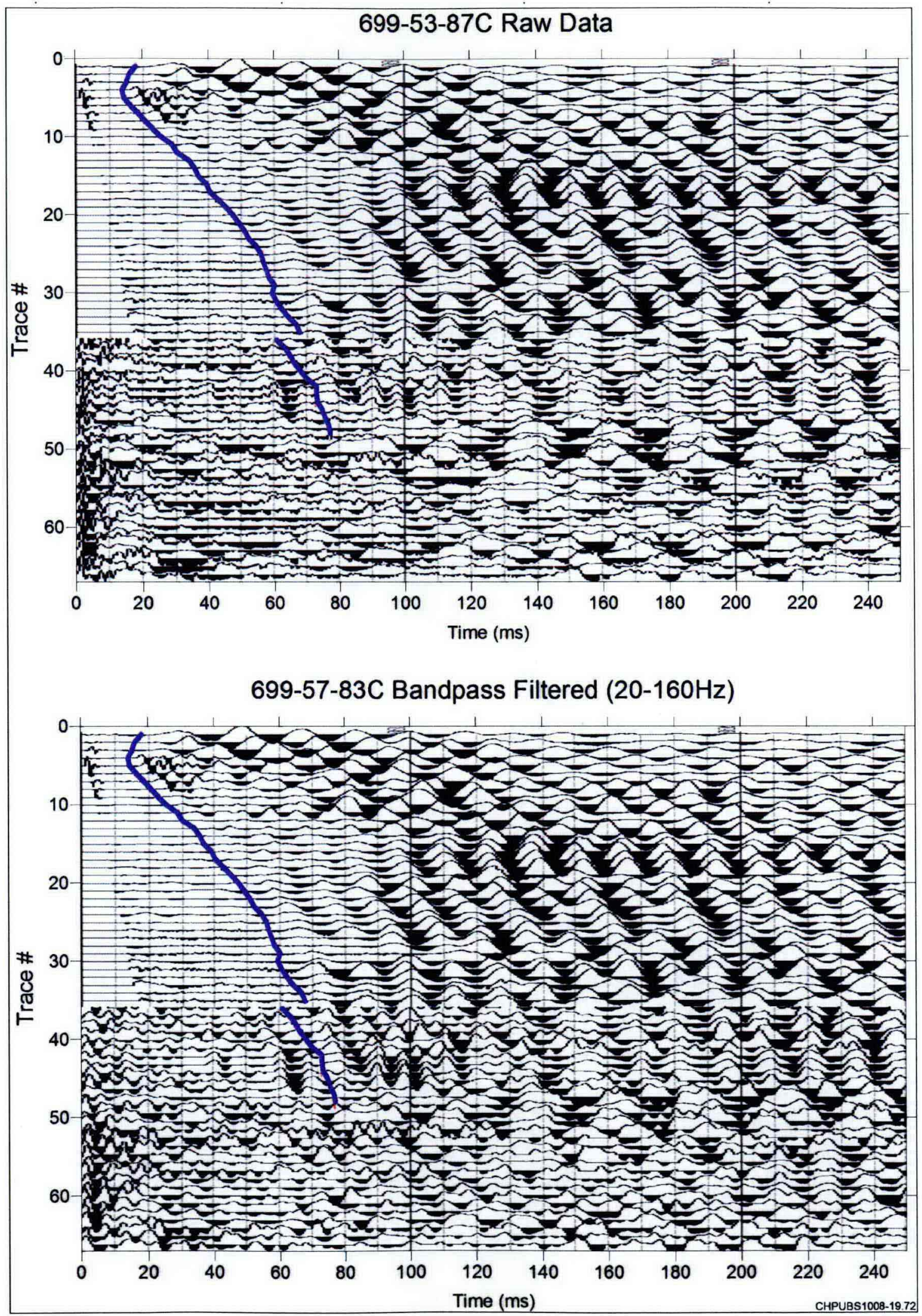

Figure A26. Check Shot: Well 699-53-87C 


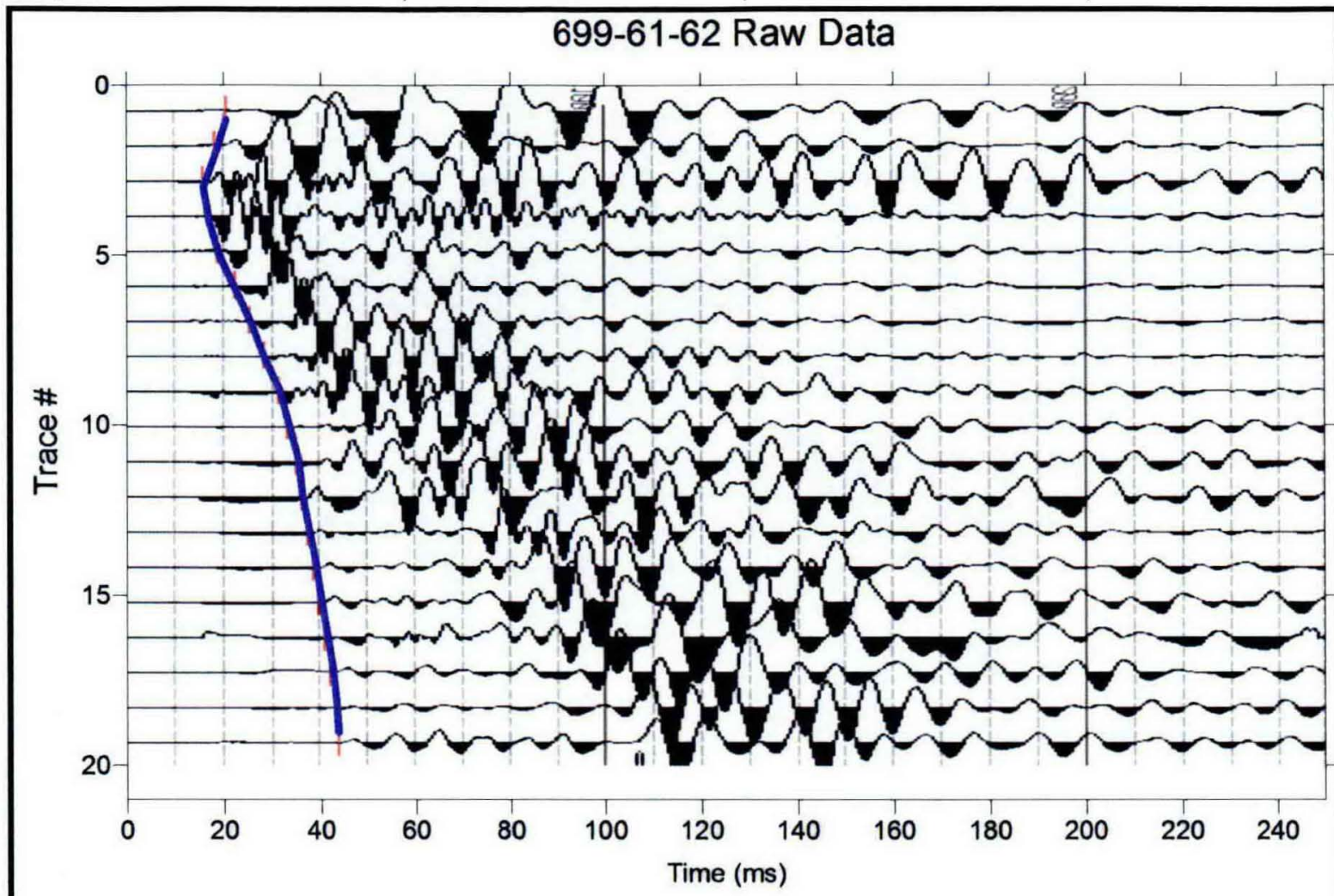

699-61-62 Bandpass Filtered $(40-280 \mathrm{~Hz})$

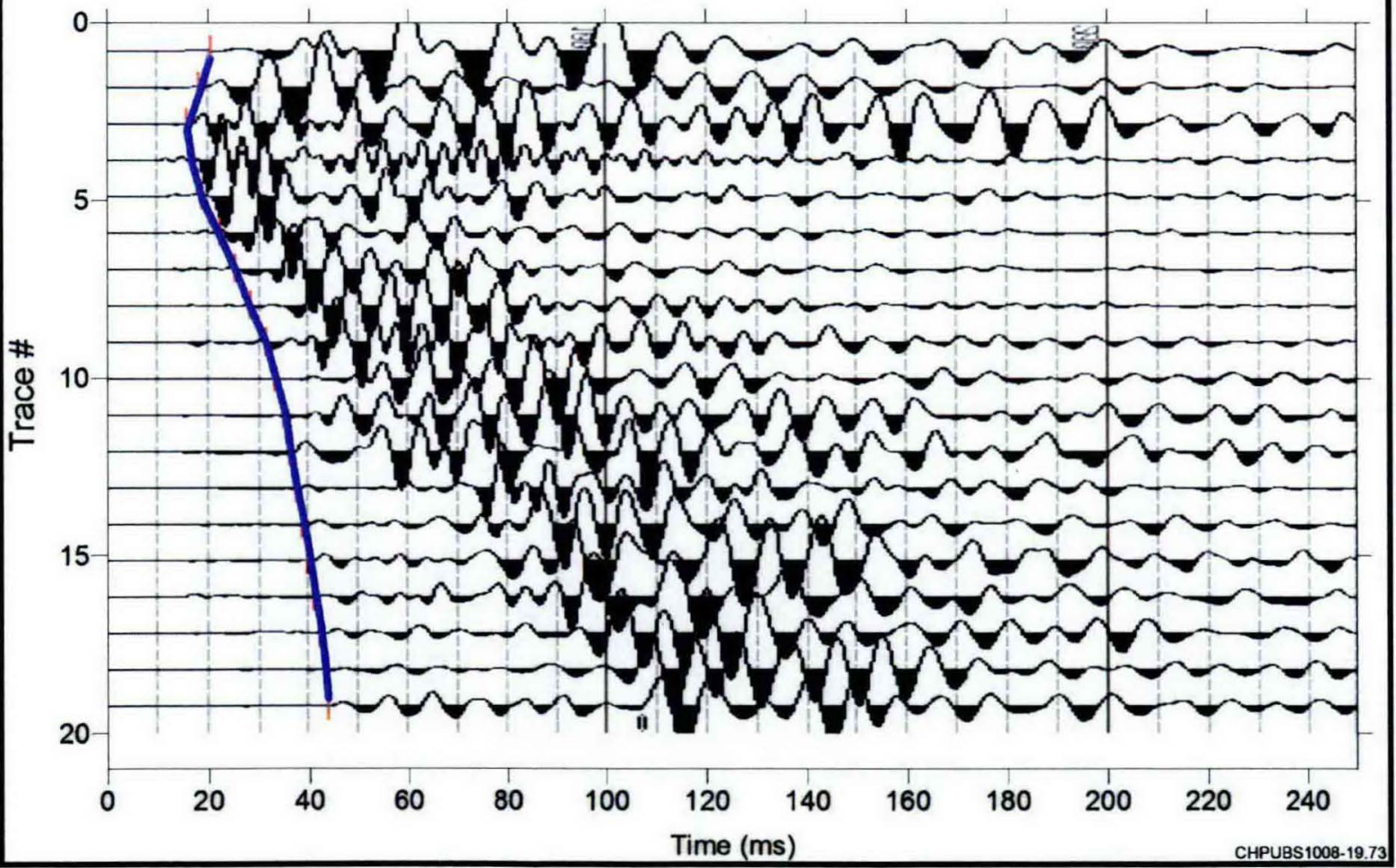

Figure A27. Check Shot: Well 699-61-62 


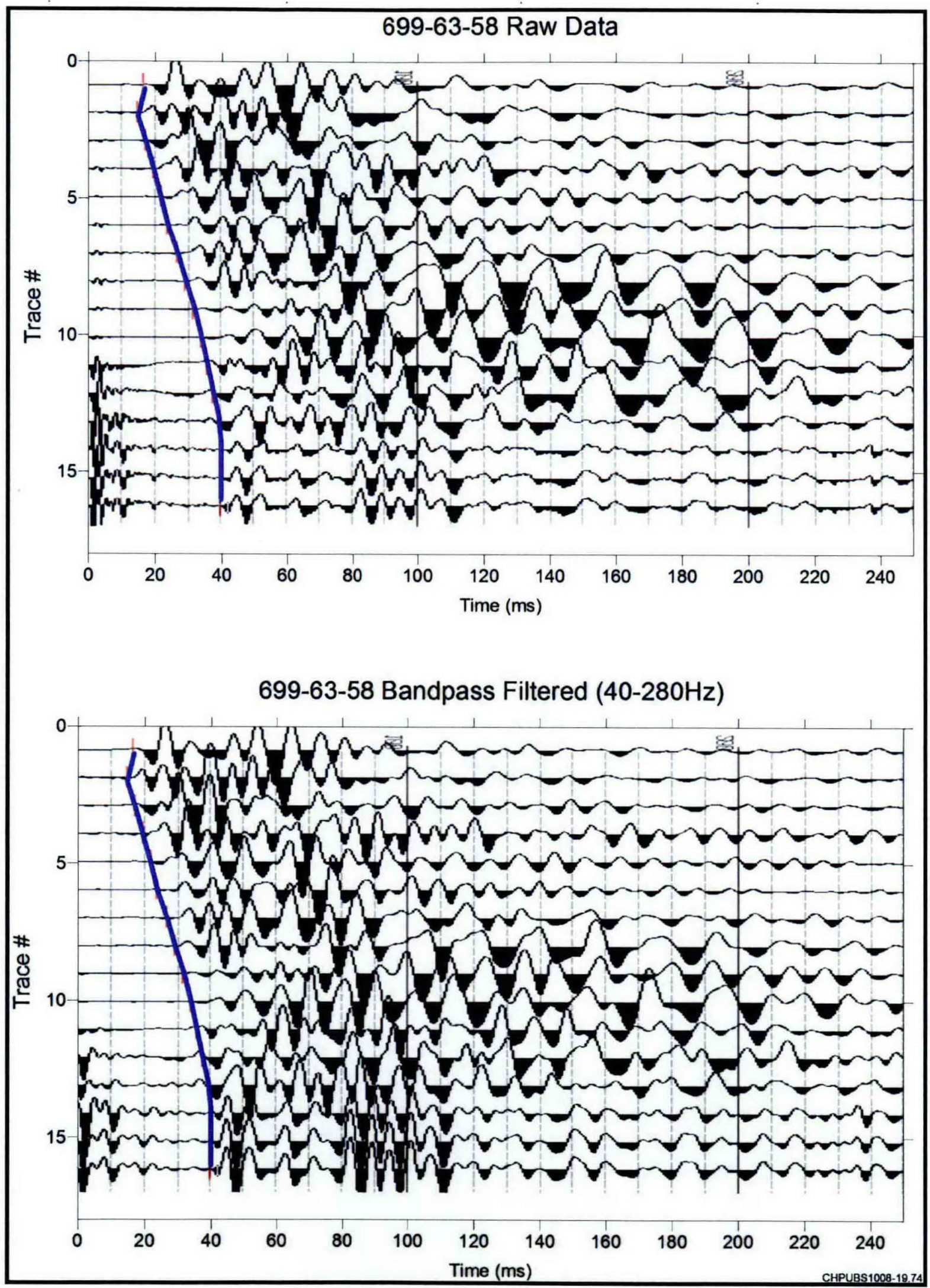

Figure A28. Check Shot: Well 699-63-58 


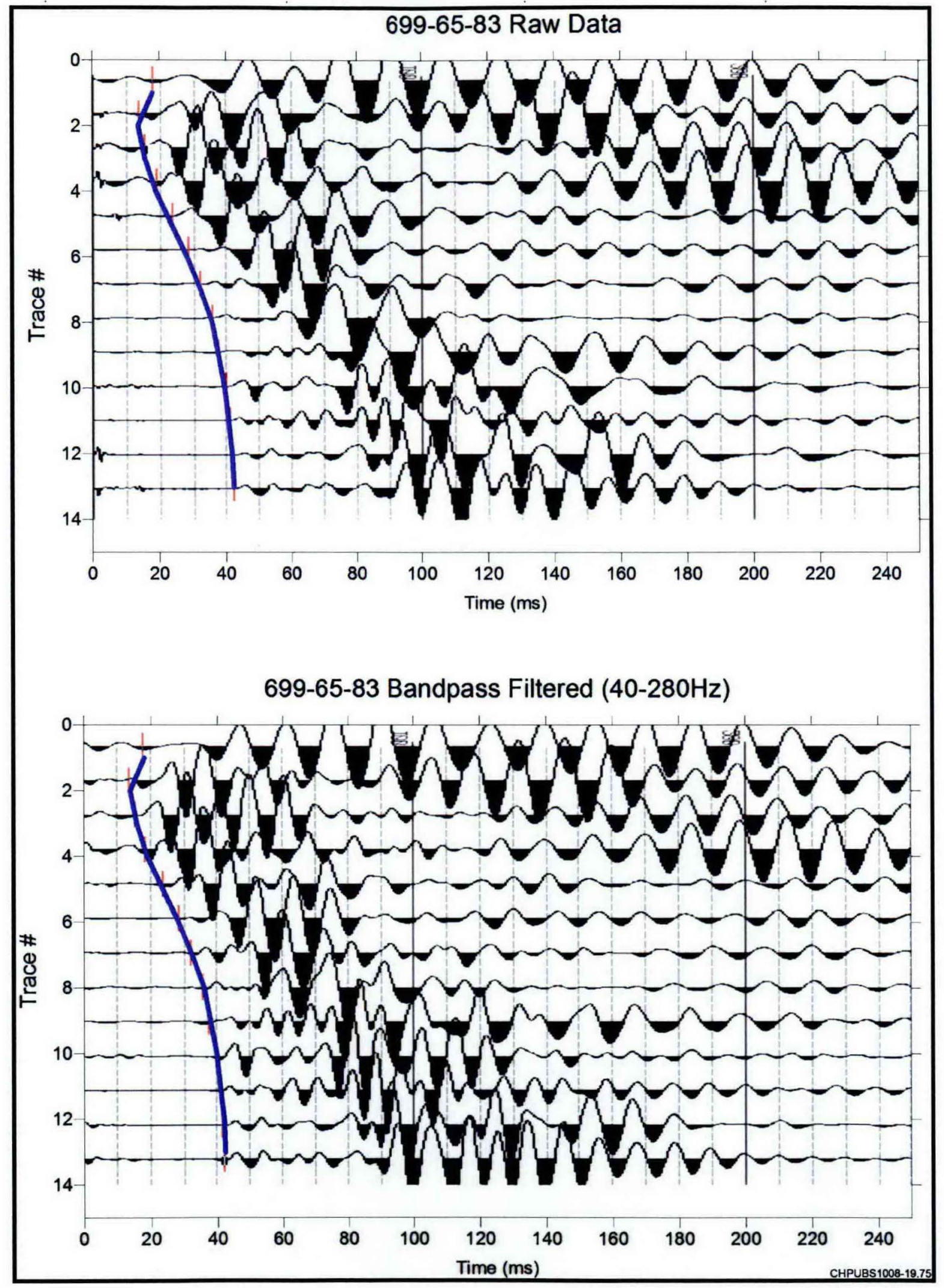

Figure A29. Check Shot: Well 699-65-83 
SGW-47535, REV. 0 